\title{
RENATA FARINELLI DE SIQUEIRA
}

Efailo imunodepressor do exercicio em equinos submotidos a provas do enduro de diferentes distâncias, suplementados ou não com glutamina

São Paulo

2014 


\section{RENATA FARINELLI DE SIQUEIRA}

Efeito imunodepressor do exercício em equinos submetidos a provas de enduro de diferentes distâncias, suplementados ou não com glutamina

São Paulo

2014 


\section{RENATA FARINELLI DE SIQUEIRA}

Efeito imunodepressor do exercício em equinos submetidos a provas de enduro de diferentes distâncias, suplementados ou não com glutamina

Tese apresentada ao Programa de PósGraduação em Clínica Médica da Faculdade de Medicina Veterinária e Zootecnia da Universidade de São Paulo para a obtenção do título de Doutor em

Ciências

Departamento

Clínica Médica

Área de Concentração

Clínica Veterinária

Orientador

Prof. Dr. Wilson Roberto Fernandes 
Autorizo a reprodução parcial ou total desta obra, para fins acadêmicos, desde que citada a fonte.

DADOS INTERNACIONAIS DE CATALOGAÇÃO-NA-PUBLICAÇÃO

(Biblioteca Virginie Buff D’Ápice da Faculdade de Medicina Veterinária e Zootecnia da Universidade de São Paulo)

Siqueira, Renata Farinelli de

Efeito imunodepressor do exercício em equinos submetidos a provas de enduro de diferentes distâncias, suplementados ou não com glutamina / Renata Farinelli de Siqueira. -2014.

$82 \mathrm{f}$. : il.

Tese (Doutorado) - Universidade de São Paulo. Faculdade de Medicina Veterinária e Zootecnia. Departamento de Clínica Médica, São Paulo, 2014

Programa de Pós-Graduação: Clínica Veterinária.

Área de concentração: Clínica Veterinária.

Orientador: Prof. Dr. Wilson Roberto Fernandes.

1. Cavalo. 2. Enduro. 3. Glutamina. 4. Linfócitos. 5. Estresse oxidativo. I. Título. 


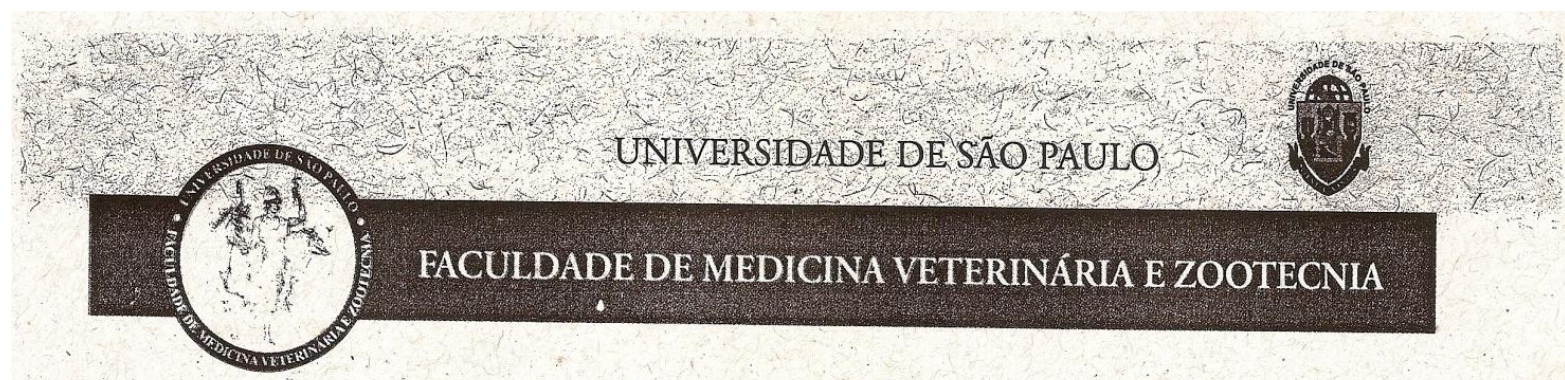

\section{Comissão de Ética no uso de animais}

\section{CERTIFICADO}

Certificamos que o Projeto intitulado "Efeito imunodepressor do exercício em equinos submetidos a provas de enduro de diferentes distâncias, suplementados ou não com glutamina", protocolado sob o $\mathrm{n}^{\circ}$ 2606/2012, utilizando 36 (trinta e seis) equinos, sob a responsabilidade do Prof. Dr. Wilson Roberto Fernandes, está de acordo com os princípios éticos de experimentação animal da "Comissão de Étíca no uso de animais" da Faculdade de Medicina Veterinária e Zootecnia da Universidade de São Paulo e foi aprovado em reunião de 14/3/2012.

We certify that the Research "Immunosuppressive effect of exercise in endurance horses competing in different distances, supplemented or not with glutamine", protocol number 2606/2012, utilizing 36 (thirty six) horses, under the responsibility Prof. Dr. Wilson Roberto Fernandes, agree with Ethical Principles in Animal Research adopted by "Ethic Committee in the use of animals". of the School of Veterinary Medicine and Animal Science of University of São Paulo and was approved in the meeting of day $3 / 14 / 2012$.

São Paulo, 5 de abril de 2012

Av. Prof. Dr. Orlando Marques de Paiva, $n^{\circ} 87$

Cidade Universitária "Armando de Salles Oliveira"

São Paulo/SP - Brasil

Fone: $+551130917671 / 7676$

Fax: + $55113032-2224$

E-mail: fmvz@usp.br http://www.fmvz.usp.br 
Autor: Siqueira, Renata Farinelli

Título: Efeito imunodepressor do exercício em equinos submetidos a provas de enduro de diferentes distâncias, suplementados ou não com glutamina.

Tese apresentada ao Programa de PósGraduação em Clínica Médica da Faculdade de Medicina Veterinária e Zootecnia da Universidade de São Paulo para obtenção do titulo de Doutor em Ciências

Data:

\section{Banca Examinadora}

Prof. Dr.:

Instituição: Julgamento:

Prof. Dr.:

Instituição: Julgamento:

Prof. Dr.:

Instituição: Julgamento:

Prof. Dr.:

Instituição: Julgamento:

Prof. Dr.:

Instituição: Julgamento: 
Minha relação com cavalos vem de muito antes de pensar em estudar veterinária. Mas, foi através do enduro e de alguns cavalos especiais que conheci e me interessei pela medicina esportiva. Dedico esse trabalho aos "Mestres" e companheiros que por tantos e tantos anos tive o privilégio de aprender com eles valiosas lições e viver os melhores momentos da minha vida.

Phe6o, foi com ele que tudo começou!

Gladiador, me mostrou o quanto o amor é capaz de transformar.

Von Herte Kim .... esse foi muito mais que um cavalo, foi minha alma gêmea. Foram 9 anos de provas e treinos, onde devo ter passado mais tempo sobre ele do que andando com minhas próprias pernas. Por ele, com ele ou através dele viajei o mundo, conheci pessoas que foram importantes na minha vida, o respeito das pessoas mais difíceis e inusitadas. Foram tantas histórias que daria um livro. Ao todo, passou 15 anos comigo, partindo durante esse trabalho. Deixou a certeza que tudo valeu a pena e que todos os minutos com ele foram os melhores da minha vida. Espero um dia, em algum lugar, encontrá-lo ..... e, quem sabe, ter a honra de mais um galope!

Billy RFS, que leva meu nome e uma boa parte do meu coração, talvez a melhor. Com ele coloquei em prática muitos conceitos que acreditava e provou ser o caminho certo.

Echo World e Turran, com eles senti na pele que a luta deve sempre ser pela vida. Isso não tem preço!

AN Classic, Kezo, Nature's Sungari, Rhamon Flame e tantos outros que por algum momento me ajudaram nessa trajetória.

Dedico também à minha mãe que sempre esteve ao meu lado, viveu e proporcionou tudo isso, com amor e apoio incondicionais! 


\section{AGRADECIMENTOS}

A Deus, que sempre colocou as pessoas certas no meu caminho e em nenhum momento me deixou sozinha!

A minha mãe, por também ter sido pai além de mãe. Por estar ao meu lado em todas as situações. Obrigada por tudo! Te amo!

Ao meu orientador, Prof. Wilson, que foi orientador de estágio na graduação, há muitos anos atrás e novamente me recebeu, acreditando no meu trabalho. Obrigada pela paciência, por estar sempre disposto a ouvir, pelos conselhos, ensinamentos, amizade e principalmente pelo modo que conduziu essa orientação, sendo um grande parceiro.

Dizem que os amigos são a família que podemos escolher. Portanto, agradeço minha irmã de coração, Renata Miranda, por sua generosidade. Sem ela não poderia ter feito 2 das 4 coletas. Obrigada pela amizade verdadeira, por suportar as ausências e pela torcida!

Ao Tio Chico, pela grande ajuda durante todo o trabalho. O que começou com um pedido de socorro se transformou em uma amizade que quero levar para sempre! Obrigada por tudo!

As amigas Rebeca e Giovanna que me ajudaram no laboratório todos os dias de coleta, de boa vontade, inclusive nos finais de semana! Obrigada pela amizade e pelo companheirismo! Aprendi demais com vocês!

A Lilian, Joice e Sandro que foram para as provas comigo e a Juliana que também ajudou no pós prova algumas vezes. Obrigada pela ajuda, amizade e torcida!

As "Bruxas", um grupo criado para unir amigas improváveis com agendas incompatíveis. Juliana, Ludmila, Rebeca e Tatiana, vocês foram uma das melhores coisas que me aconteceu nesse período. Cada uma com sua personalidade fizeram a diferença em muitos momentos. Estiveram comigo na alegria e na tristeza e a confiança e amizade construídas, não tem preço! Obrigada meninas! E, se a vida nos separar, levarei cada uma no coração!

A Clara, Claudia e Samantha pela grande ajuda no laboratório e ensinamentos. Sem a colaboração de vocês, ficaria impossível! 
A todos os veterinários do enduro que me ajudaram a convencer os proprietários ou que permitiram e facilitaram as coletas no dia do evento, Gerson, Beto Turato, Henrique, Danilo, Gustavo, Paulo Griska, Paulo Fasano, Carlão e Elaine.

A todos os proprietários e cavaleiros que permitiram a realização da coleta, sem nenhuma restrição e me receberam em seus haras de braços abertos. Um agradecimento especial aos que suplementaram os cavalos. Obrigada pela confiança! Aos funcionários pela imensa paciência, boa vontade e educação. São eles Equipe Haras Endurance (Leo, André, Mônica, Júlio e Alemão), Equipe Odyssey Riders (Ana Carla, Olavo, Adriano e Rogério), Equipe Santa Clara (Patrícia e Yara), Equipe São Bento (Higor, Alexandre e Felipe), Equipe Haras Morada do Sol (Ślvio, Karina e Valdir), Centro de Treinamento Le Domaine (Aude, Mané e Toninho) e CT Marechal (Almeida, Renato, Família Toledo, Maia e funcionários).

A todos os professores desta instituição responsáveis pelo meu aprimoramento e formação profissional, especialmente as professoras Alice e Macau pela disposição em ajudar sempre e todos os conselhos e ensinamentos.

Ao Dr. Laguna, exemplo de ética e caráter. Um amigo muito querido, sempre disposto a ouvir, ajudar e aconselhar. Obrigada por tudo que me ensinou e por até hoje ser um porto seguro!

À Equipe Santa Gertrudes de enduro (Valéria, Paulo, Dani, Léo e Rogério) pela amizade e confiança depositada no meu trabalho que permitiu colocar em prática os conhecimentos adquiridos.

À FAPESP por ter concedido recursos financeiros para o desenvolvimento do projeto de pesquisa e pela concessão da bolsa durante meus estudos de doutorado. 


\section{RESUMO}

SIQUEIRA, R. F. Efeito imunodepressor do exercício em equinos submetidos a provas de enduro de diferentes distâncias, suplementados ou não com glutamina. [Immunosuppressive effect of exercise in horses submitted to different distances endurance races, supplemented or not with glutamine]. 2014. $82 \mathrm{f}$. Tese (Doutorado em Ciências) - Faculdade de Medicina Veterinária e Zootecnia, Universidade de São Paulo, São Paulo, 2014.

Os objetivos desse trabalho foram avaliar se provas de enduro de diferentes distâncias causam estresse em equinos treinados, avaliar os efeitos das provas de enduro de diferentes distâncias sobre a atividade dos linfócitos e a relação com a imunocompetência dos equinos atletas e investigar a suplementação alimentar com glutamina como possível atenuante desse efeito depressivo do estresse sobre 0 sistema imunológico. Foram utilizados 33 cavalos treinados para enduro, 13 em 80 km, 14 em 120 km e 6 em 160 km, avaliados em 4 provas. Metade dos cavalos de cada categoria recebeu suplementação com glutamina via oral 30 dias antes e 14 dias após as provas. Amostras de sangue venoso foram colhidas antes (M0), imediatamente após a última inspeção veterinária (M1), 3 horas depois (M2) e nos haras 3 (M3), 7 (M4), e 14 dias (M5). Houve aumento dos níveis de cortisol, amônia, neutrófilos, aumento da relação neutrófilos/linfócitos e diminuição da contagem de linfócitos em M1 e M2 em todos os cavalos. Houve diminuição da relação CD4/CD8 nos animais de 120 (M2, M3 e M4) e 160 km (M3) que não receberam suplementação e diminuição de IFNy em todos os cavalos. Nos suplementados, houve diminuição da relação CD4/CD8 em 80 (M2), 120 (M2 e M3) e 160 km (M3 e M4) e aumento tardio de IFNy (M4 e M5) nos cavalos de 80 e $120 \mathrm{~km}$. As concentrações de IL-2, IL-4 e IL-10 aumentaram após a prova em todos os cavalos, porém, nos suplementados o aumento foi maior ou mais prolongado. Com base nesses resultados, não foi possível observar estresse nos animais, nem imunodepressão, embora a suplementação tenha exercido efeito sobre os linfócitos.

Palavras-chave: Cavalo. Enduro. Glutamina. Linfócitos. Estresse oxidativo. 


\begin{abstract}
SIQUEIRA, R. F. Immunosuppressive effect of exercise in horses submitted to different distances endurance races, supplemented or not with glutamine. [Efeito imunodepressor do exercício em equinos submetidos a provas de enduro de diferentes distâncias, suplementados ou não com glutamina]. 2014. 82 f. Tese (Doutorado em Ciências) - Faculdade de Medicina Veterinária e Zootecnia, Universidade de São Paulo, São Paulo, 2014.
\end{abstract}

The objectives of this study were to assess whether a different distances endurance races cause stress in trained horses, assess the effects of different distances an endurance races on the lymphocytes and relationship with the immune competence of equine athletes and investigate dietary supplementation with glutamine as possible mitigating this depressive effect of stress on the immune system . 33 well trained endurance horses were used, 13 at $80 \mathrm{~km}, 14$ and $120 \mathrm{~km}$ and 6 in $160 \mathrm{~km}$ in 4 endurance rides. Half of the horses in each category received oral supplementation with glutamine to 30 days before and 14 days after the race. Venous blood samples were collected before (M0), immediately after the last veterinary inspection (M1), 3 hours after (M2) and in their farms 3 (M3), 7 (M4) and 14 days (M5) after. There was an increase in cortisol levels, ammonia and neutrophils, increase in neutrophils / lymphocytes ratio and reduction in lymphocyte counts at $\mathrm{M} 1$ and $\mathrm{M} 2$ in all horses. There was a decrease in LT CD4/CD8 ratio in 120 (M2, M3 and M4) and $160 \mathrm{~km}$ (M3) without supplementation and either a decreased in IFN in all animals. Horses that had received glutamine supplementation showed a decreased in CD4/CD8 ratio in 80 (M2), 120 (M2 and M3) and $160 \mathrm{~km} \mathrm{(M3} \mathrm{and} \mathrm{M4)} \mathrm{and} \mathrm{late} \mathrm{increase} \mathrm{of} \mathrm{IFNy} \mathrm{(M4}$ and M5) in 80 and $120 \mathrm{~km}$. INFY production was increased later (7 and 14 days) in 80 and $120 \mathrm{~km}$ horses that received supplementation and decreased in all $160 \mathrm{~km}$. The concentrations of IL-2, IL-4 and IL-10 increased after the race on all horses , but the increase was greater or more prolonged in supplemented ones. Based on these results, it was not possible to observe stress in these animals, or immunosuppression either, although supplementation has exerted effects on lymphocytes.

Keywords: Horse. Endurance. Glutamine. Lymphocytes. Oxidative stress. 


\section{LISTA DE ILUSTRAÇÕES}

Figura 1 - Metabolismo da glutamina e glutamato em células de mamíferos

Figura 2 - Diferença entre momentos de coleta do cortisol nos cavalos de $80 \mathrm{~km}$, suplementados ou não com glutamina

Figura 3 - Diferença entre momentos de coleta do cortisol nos cavalos de $120 \mathrm{~km}$, suplementados ou não com glutamina

Figura 4 - Diferença do cortisol entre os momentos de coleta dos cavalos de $160 \mathrm{~km}$ suplementados com glutamina

Figura 5 - Diferenças entre momentos no número de eosinófilos nos cavalos de $80 \mathrm{~km}$, quanto à suplementação de glutamina

Figura 6 - Diferenças entre momentos no número de eosinófilos nos cavalos de $120 \mathrm{~km}$, quanto à suplementação de glutamina .52

Figura 7 - Diferença no número de linfócitos nos momentos de coleta dos cavalos de 80 suplementados com glutamina

Figura 8 - Diferença no número de linfócitos nos momentos de coleta dos cavalos de 120 suplementados com glutamina

Figura 9 - Diferença na relação entre LT CD4/CD8 em M2 nas diferentes distâncias, sem suplementação, segundo o teste de KruskalWallis

Figura 10 - Diferença na relação entre LT CD4/CD8 em M2 nas diferentes distâncias, com suplementação, segundo o teste de KruskalWallis

Figura 11 - Diferença na concentração de IL-2, em M3 nos cavalos de $120 \mathrm{~km}$, quanto à suplementação com glutamina

Figura 12 - Diferença na concentração de IL-2, em M5 nos cavalos de 120 km, quanto à suplementação com glutamina

Figura 13 - Diferença na concentração de IL-4, em M3 nos cavalos de $120 \mathrm{~km}$, quanto à suplementação com glutamina

Figura 14 - Diferença na concentração de IL-4, em M4 nos cavalos de $120 \mathrm{~km}$, quanto à suplementação com glutamina 
Figura 15 - Diferença na concentração de IL-4, em M5 nos cavalos de $120 \mathrm{~km}$, quanto à suplementação com glutamina 


\section{LISTA DE TABELAS}

Tabela 1 - Valores das medianas, primeiro e terceiro quartis das variáveis SOD, GPx, GSH, MDA e CAT nos cavalos que competiram em 80, 120 e 160 km, suplementados ou não com glutamina

Tabela 2 - Valores da mediana, primeiro e terceiro quartis de glutamina e amônia séricas nos cavalos que competiram em 80, 120 e $160 \mathrm{~km}$, suplementados ou não com glutamina

Tabela 3 - Valores da mediana, primeiro e terceiro quartis de cortisol e hormônio do crescimento (GH) nos cavalos que competiram em 80, 120 e 160 km, suplementados ou não com glutamina

Tabela 4 - Valores da mediana, primeiro e terceiro quartis de eosinófilos, neutrófilos e linfócitos nos cavalos que competiram em 80, 120 e 160 km, suplementados ou não com glutamina

Tabela 5 - Valores da mediana, primeiro e terceiro quartis das relações entre neutrófilos e linfócitos e linfócitos T CD4 e CD8 nos cavalos que competiram em 80, 120 e 160 km, suplementados ou não com glutamina

Tabela 6 - Valores da mediana, primeiro e terceiro quartis de IFNy, IL-2, IL-4 e IL-10 nos cavalos que competiram em 80, 120 e 160 $\mathrm{km}$, com ou sem suplementação de glutamina 


\begin{tabular}{|c|c|}
\hline LT & linfócitos T \\
\hline LTh & linfócitos T helper \\
\hline LTC & linfocitose $T$ citotóxicos \\
\hline LT reg & linfócito T regulador \\
\hline LB & linfócitos B \\
\hline MHC & complexo de histocompatibilidade maior \\
\hline IFNy & interferon gama \\
\hline IL-2 & interleucina 2 \\
\hline IL-4 & interleucina 4 \\
\hline IL-6 & interleucina 6 \\
\hline IL-8 & interleucina 8 \\
\hline IL-10 & interleucina 10 \\
\hline IL-12 & interleucina 12 \\
\hline TNF & fator de necrose tumoral \\
\hline NK & células natural killer \\
\hline TGF $\beta$ & fator de transformação do crescimento beta \\
\hline $\mathrm{VO}_{2 \max }$ & velocidade de consumo máximo de oxigênio \\
\hline ACTH & hormônio corticotrófico \\
\hline $\mathrm{GH}$ & hormônio do crescimento \\
\hline IGF-1 & fator de crescimento semelhante à insulina \\
\hline
\end{tabular}




$\begin{array}{ll}\text { ATP } & \text { adenosina trifosfato } \\ \text { EROS } & \text { espécies reativas de oxigênio } \\ \text { NADPH } & \text { nicotinamida adenina dinucleotídio fosfato } \\ \text { GSH } & \text { glutationa reduzida } \\ \text { SOD } & \text { superóxido dismutase } \\ \text { CAT } & \text { catalase } \\ \text { GPX } & \text { glutationa peroxidase } \\ \text { MDA } & \text { malondialdeído } \\ \text { GSSG } & \text { glutationa oxidada } \\ \text { EDTA } & \text { ácido etilenodiaminotetracético } \\ \text { DMSO } & \text { dimetilsulfóxido } \\ \text { PBS } & \text { tampão fosfato-salino }\end{array}$




\section{SUMÁRIO}

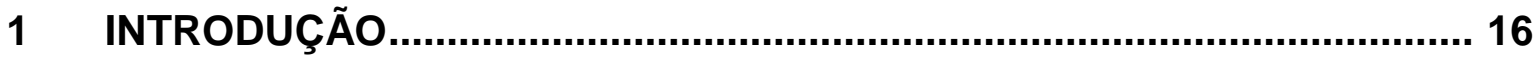

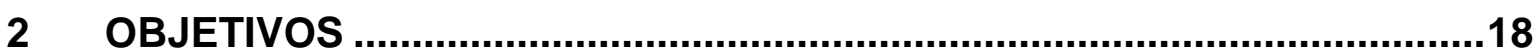

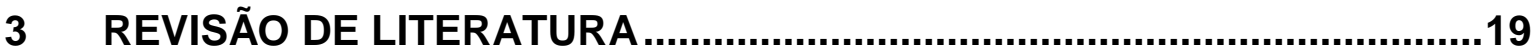

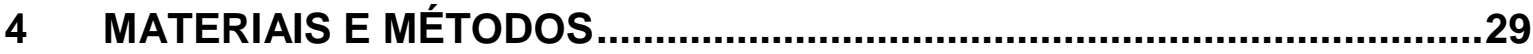

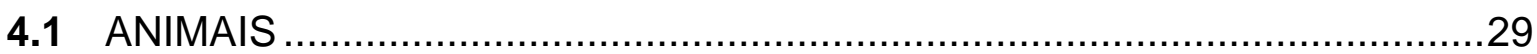

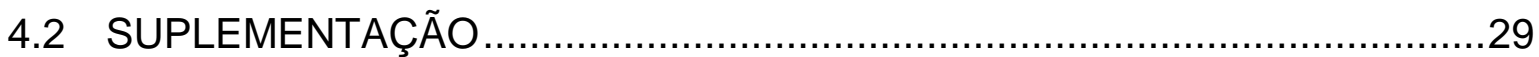

4.3 COLHEITA DE SANGUE E PROCESSAMENTO DAS AMOSTRAS ............30

4.4 VARIÁVEIS DE ESTRESSE OXIDATIVO ……...........................................

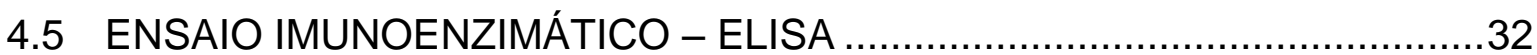

4.6 ESTUDO PILOTO DE CONGELAMENTO E VIABILIDADE DE

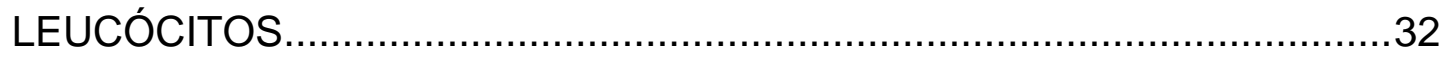

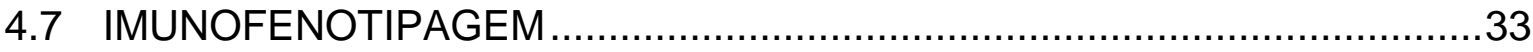

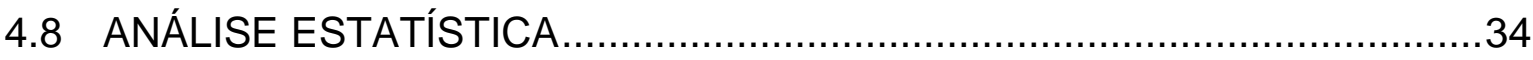

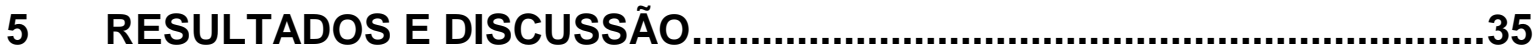

6 CONCLUSÃO

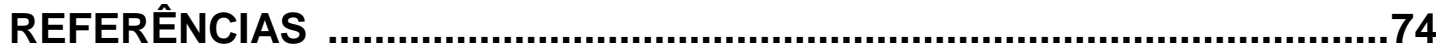




\section{INTRODUÇÃO}

O Enduro equestre é um esporte amador praticado em 61 países, contando com cerca de 40 mil competidores, segundo dados fornecidos pela Confederação Brasileira de Hipismo. Os conjuntos cumprem distâncias de 20 a 160 km em um dia ou de 200 até $500 \mathrm{~km}$ em até cinco dias, sendo que os cavalos devem ser aprovados em todas as inspeções veterinárias. As provas de velocidade livre são divididas em três categorias, 80, 120 e $160 \mathrm{~km}$, adultos e young riders, realizadas contra o relógio, mas os campeonatos mundiais contam somente com $160 \mathrm{~km}$ para adultos e $120 \mathrm{~km}$ para jovens cavaleiros.

Em 1955 foi realizada nos Estados Unidos a primeira prova de Enduro equestre oficial, a Tevis Cup, considerada uma das trilhas mais difíceis do mundo até hoje. No Brasil, a primeira competição aconteceu em 1989, sendo que somente em 1990, o esporte foi reconhecido e federado. Desde então, a equipe brasileira de másteres (adultos) participou de 14 edições de campeonatos mundiais sem obter medalhas, porém, com seu desempenho melhorando a cada participação. Nos últimos anos foram três oitavas colocações, uma sexta e uma quarta. Já a equipe de jovens cavaleiros participa desde 2001, onde obteve duas medalhas de bronze e o tão almejado prêmio "Best Condition" para uma das éguas em 2003, na Itália.

O esporte, apesar de ainda amador, está se profissionalizando, as pessoas envolvidas procurando mais por informações. Com a entrada dos povos árabes no esporte criou-se um mercado de cavalos enduristas e as médias de velocidade crescem a cada dia. O Campeonato Mundial de 2008, realizado na Malásia, foi vencido com uma velocidade de 18,16 km/h. Em 2010, no World Equestrian Games realizado no Kentucky (EUA), a velocidade média de prova do vencedor foi 21,07 $\mathrm{km} / \mathrm{h}$. Em 2012, o Mundial da Inglaterra foi vencido com velocidade média de 22,82 $\mathrm{km} / \mathrm{h}$.

Muito se estuda sobre exercício de resistência, mas a grande maioria desses trabalhos ainda é realizada em esteiras rolantes, em ambientes controlados. Poucos estudos são realizados a campo, onde há influencia direta do cavaleiro, terreno e clima. A busca por novos conhecimentos e execução de pesquisas deve atender esse importante e crescente mercado, visando o bem estar animal, assim como melhora do desempenho atlético e diminuição de lesões decorrentes de treinamento 
e a minimização de prejuízos econômicos. O conhecimento da fisiologia do exercício é de fundamental importância para o entendimento tanto do processo adaptativo às crescentes cargas de esforço impostas pela profissionalização do esporte quanto de elaboração de esquemas de treinamento, alimentação e suplementação desses atletas. 


\section{OBJETIVOS}

Avaliar se provas de enduro de diferentes distâncias causam estresse em equinos treinados.

Avaliar os efeitos das provas de enduro de diferentes distâncias sobre a atividade dos linfócitos e a relação com a imunocompetência dos cavalos atletas.

Investigar a suplementação alimentar de glutamina como possível atenuante do efeito depressivo do estresse sobre o sistema imunológico. 


\section{REVISÃO DE LITERATURA}

A associação entre exercício e susceptibilidade a infecções é reconhecida em humanos desde 1918, quando um estudo comprovou que a pneumonia era mais comum em atletas que em indivíduos sedentários e, o exercício extenuante aumentava o risco de infecções do trato respiratório superior progredirem para pneumonia (COWLES, 1918). A partir daí muitos estudos investigaram a relação entre exercício, resposta imune e doença, levando ao reconhecimento que o estresse causado pelo exercício provoca profundos, porém variados, efeitos no sistema imune. Apesar de, comparativamente, pouco se conhecer sobre os efeitos específicos do exercício no sistema imune de animais domésticos, o fato de cavalos e outros animais praticarem exercícios extenuantes, torna esse assunto muito importante para a Medicina Veterinária (HINES et al., 1996).

Ao mesmo tempo em que alterações funcionais em neutrófilos e linfócitos são encontradas em humanos após sessões de exercício de várias intensidades, Jensen-Weaern e Fossum (1993) não encontraram nenhuma alteração nesses tipos celulares, em suínos submetidos a exercício físico. Por outro lado, Anderson et al. (1991) relataram que o exercício em esteira rolante aumentou a severidade da doença em vacas inoculadas experimentalmente com Pasteurella haemolytica (ROSE et al., 2000).

Definir a relação entre exercício, imunidade e susceptibilidade à infecção é um trabalho árduo devido à complexidade do sistema imunológico e à própria variabilidade entre os exercícios. É comprovado tanto em humanos quanto em ratos e camundongos que o exercício extenuante induz modificações tanto na imunidade inata quanto na adquirida, diminuindo a relação de neutrófilos e linfócitos, assim como suas atividades. Apesar de alterações similares serem esperadas na espécie equina, as conclusões das pesquisas realizadas em humanos e roedores não podem ser extrapoladas e aplicadas diretamente nos cavalos pelas diferenças fisiológicas quanto às respostas ao exercício (CYWIŃSKA et al., 2010).

Em humanos, o exercício agudo diminui a resposta proliferativa de linfócitos a mitógenos e quando a sessão de exercício é extenuante e prolongada $(>1,5 \mathrm{~h})$, o número dessas células fica abaixo dos níveis pré-exercício por várias horas após o término do exercício e a razão de linfócitos $T \mathrm{CD} 4^{+} / \mathrm{CD} 8^{+}$diminui (GLEESON, 2007). 
No sistema imune de mamíferos, linfócitos T e B se diferenciam sob sinalização de outras células recebida pela medula óssea e timo. No timo, os linfócitos $T$ helper CD4 e linfócitos T citotóxicos CD8 surgem a partir de um mesmo precursor duplopositivo $\mathrm{CD}^{+} \mathrm{CD}^{+}(\mathrm{Tp})$. Uma vez produzidos, a resposta dos linfócitos T CD4 e CD8 serão selecionadas de acordo com o antígeno associado ao MHC classe II (complexo de histocompatibilidade) para linfócitos T CD4 ou MHC classe I para linfócitos T CD8 (CALLARD, 2007).

O predomínio da imunidade humoral ou mediada por células é dependente das citocinas liberadas pelos linfócitos $T$ helper ativados (GLEESON, 2007). Após a ativação do linfócito $T$ helper $\left(T_{h}\right)$ as células se desenvolvem em subgrupos denominados $T_{h 1}, T_{h 2}, T_{h 17}$ e $T_{\text {reg }}$ (células reguladoras). Essas células dos subgrupos expressam diferentes citocinas e mediam distintas funções efetoras durante a resposta imune. As células $T_{h 1}$ são caracterizadas pela produção de IFNy (interferon gama), responsável pela defesa contra muitos patógenos intracelulares (WAGNER et al., 2010). Também produzem IL-2, citocina conhecida como fator de crescimento de células T. Esta é uma glicoproteína que participa continuamente tanto do amadurecimento quanto da ativação das células $T$, aumenta a atividade das células NK (natural killer) e promovem a proliferação das células B ativadas (DOHMANN et al., 2000). As células $T_{h 2}$ são caracterizadas pela produção de IL-4, IL-5 e IL-13, que promovem o desenvolvimento de uma resposta mediada por anticorpos contra bactérias e parasitas extracelulares (WAGNER et al., 2010). A IL-4 é conhecida como fator de crescimento-1 de células $B$ e também induz a expressão de MHCclasse II (DOHMANN et al., 2000).

Linfócitos $\mathrm{TCD}^{+}$helper $\left(\mathrm{T}_{\mathrm{h}}\right) \mathrm{T} \quad \mathrm{CD}^{+}$citotóxicos $\left(\mathrm{T}_{\mathrm{c}}\right)$ e regulatórios $\left(\mathrm{T}_{\text {reg }}\right)$ orquestram a resposta imune adaptativa em mamíferos (REINER, 2009). No timo $T_{h}$ CD4 e $T_{c}$ CD8 se originam de um mesmo precursor que expressa ambos CD4 e CD8. A resposta da célula $T$ é selecionada de acordo com o antígeno associado ao MHC de classe II (para célula T CD4) ou MHC de classe I (para célula T CD8). As células $T$ se diferenciam em $T_{h 1}$ ou $T_{h 2}$ dependendo do patógeno ou do fator que desencadeie a resposta imune. Célula Th $\mathrm{h}_{1}$ produz IFNy, TNF e IL-2 responsáveis pela proteção intracelular contra vírus, bactérias e protozoários, ativando macrófagos e induzindo células $T$ citotóxicas, conduzindo a resposta imune mediada por células. Enquanto que as $\mathrm{Th}_{2}$ produzem IL-4, IL-5 e IL-13 necessárias para a produção da resposta imune humoral, produção e ativação de mastócitos, 
eosinófilos, reações alérgicas mediadas por lgE e eliminar parasitas extracelulares. $O$ precursor de CD4 também pode se transformar em $T_{\text {reg que produz IL-10, }}$, responsável por suprimir as respostas imunes (CALLARD, 2007). A IL-4 juntamente com a IL-10 (que também é produzida por monócitos e células $B$ ) podem inibir a produção de citocinas de $T_{h 1}$ e aparentemente, o exercício pode influenciar o balanço da produção das citocinas $T_{h 1}$ e $T_{h 2}$ (GLEESON, 2007). De acordo com a elevação das citocinas IL-6, IL-10 e IL-1ra, o exercício extenuante diminui a porcentagem de células $T_{h 1}$ na circulação, enquanto que as $T_{h 2}$ não sofrem alteração. Tanto o cortisol quanto a epinefrina suprimem a produção de citocinas de células $T_{h 1}$ e a IL-6 estimula diretamente a produção de citocinas pelas células $T_{h 2}$ (LANCASTER et al., 2004).

As células $T_{\text {reg }}$ expressam TGF- $\beta$ e IL-10 e possuem como funções a manutenção da tolerância imunológica, limitação da inflamação durante processos autoimunes e regulação da imunidade (WAGNER et al., 2010). A função supressiva da IL-10 envolve a inativação de macrófagos e células dendríticas através da inibição da secreção de citocinas pró-inflamatórias e expressão do MHC classe II e isso tem efeito direto na supressão da resposta $T_{h 1}$. Essa citocina também é produzida por outras células, que incluem linfócitos $B$, mastócitos, eosinófilos, macrófagos, células dendríticas e $\mathrm{LT} \mathrm{CD}^{+}$, ou seja, como essa potente citocina anti-inflamatória é produzida tanto por células $T_{h 1}$ quanto $T_{h 2}$, faz um controle por retroalimentação da resposta inflamatória dessas células (O'GARRA; VIEIRA, 2007).

Aparentemente, o exercício pode alterar o balanço entre a produção de citocinas por células $T_{\mathrm{h} 1} / T_{\mathrm{h} 2}$. Alguns estudos demonstraram que a intensidade do exercício de resistência $\left(70-85 \% \quad V_{2 m a x}\right)$ induz uma alteração bifásica na contagem dos leucócitos (NIEMAN et al., 1995; PEDERSEN et al., 1998; SUSUKI et al., 1999). Imediatamente após o exercício, o número dos leucócitos totais aumenta 50-100\%. Após 30 minutos de recuperação, a contagem de linfócitos começa a cair 30-60\% dos valores basais, permanecendo baixa por 3-6 horas.

O exercício afeta tanto a contagem total de leucócitos como os linfócitos especificamente, alterando não só o número de células quanto a resposta proliferativa. Além disso, a produção de imunoglobulinas fica prejudicada e a atividade das natural killers aumenta durante o exercício, seguido de supressão no período de recuperação. Ajustes cardiopulmonares desempenham um papel fundamental na resposta linfocitária durante a atividade física. Os linfócitos 
possuem receptores adrenérgicos e o exercício intenso está associado com um aumento dos níveis de catecolaminas, que aumentam o fluxo sanguíneo nos músculos esqueléticos e diminui nas vísceras, inclusive no baço que contém grande número de linfócitos. Logo após o exercício, desenvolve-se um período de hipotensão onde haverá diminuição do tônus simpático. A alteração de fluxo sanguíneo nas vísceras pode ser um dos fatores de alteração no número de linfócitos circulantes (NIELSEN, 2003). Todavia, se o exercício foi moderado (50\% $\mathrm{VO}_{2 \max }$ ), a contagem dos linfócitos não diminui no período de recuperação, mas a concentração sofre uma leve diminuição após a primeira hora de recuperação e grande quantidade de células são liberadas do compartimento de reserva da medula óssea, permanecendo alta por muitas horas (RiS $\varnothing Y$ et al., 2003).

Os mecanismos responsáveis pelas modificações nos números de leucócitos e função em resposta ao exercício são complexos, embora, acredita-se que hormônios neuroendócrinos desempenhem papel crucial (HINES et al., 1996). Durante o exercício tanto o sistema nervoso autônomo quanto o eixo hipotalâmico-hipofisárioadrenal são ativados e aumentam os níveis circulantes de hormônio adrenocorticotrófico (ACTH), cortisol adrenalina e noradrenalina. A adrenalina inibe a liberação de insulina pelo pâncreas e, juntamente com a noradrenalina, aumentam a quebra do glicogênio muscular. No fígado, as catecolaminas em conjunto com o cortisol, contribuem para o aumento da glicemia, através da ativação da quebra do glicogênio hepático e neoglicogênese. Além dos efeitos metabólicos, as catecolaminas aumentam a oxigenação durante o exercício pelo aumento do débito cardíaco, liberação de hemáceas armazenadas no baço e fluxo sanguíneo muscular. A homeostase cardiovascular é mantida pelas modificações da atividade da renina no plasma e na concentração de peptídeo natriurético atrial (ANP), vasopressina e aldosterona (HYYPPÄ, 2005).

Hormônios da pituitária também podem afetar o sistema imune independentemente do sistema nervoso autônomo, através de interações parácrinas ou autócrinas com o sistema imune. O resultado disso é a regulação dos hormônios da pituitária pelas citocinas que agem diretamente na glândula (KELLEY et al., 2007).

O hormônio do crescimento $(\mathrm{GH})$ é produzido principalmente na pituitária, porém, também pode ser produzido por células do sistema imune. O principal efeito do GH é promover o crescimento longitudinal na vida pós-natal. Também regula 0 
metabolismo de carboidratos, lipídios, nitrogênio e minerais. Muitas de suas ações são mediadas pela indução do IGF-1 em locais de ação e fígado. O GH e IGF-1 desempenham importante papel no desenvolvimento e manutenção da função do sistema imune, pois contribuem na liberação de imunoglobulinas pelas células $B$, secreção de timulina pelas células epiteliais do timo, atividade de células NK, ativação da fagocitose, burst oxidativo e capacidade de matar tanto dos macrófagos, quanto dos neutrófilos (KELLEY et al., 2007).

O aumento significativo na concentração de cortisol e catecolaminas no sangue e a magnitude dessas modificações são influenciados tanto pela duração quanto intensidade do exercício, assim como pelo nível de treinamento que se encontra o indivíduo. Respostas hormonais nos equinos são consistentes e semelhantes às das outras espécies. Aumento da concentração sanguínea das catecolaminas media a leucocitose durante o exercício, enquanto que o cortisol media a leucocitose após o exercício, além de afetarem também a função dessas células. Glicocorticóides são imunossupressivos, pois inibem a fagocitose pelos macrófagos, a secreção de IL-2, ativação de $\mathrm{LT} C D 4^{+}$e atividade lítica das células NK. As catecolaminas prejudicam a função do sistema imune aumentando a atividade intracelular da adenosina monofosfato, o que inibe a resposta a mitógenos tanto das células $T$ quanto das células $B$, além de alterar a função das células NK. Esse período pós exercício de imunossupressão pode deixar o atleta mais susceptível à infecções (HINES et al., 1996).

O exercício também modula o metabolismo de glicose e glutamina que influenciam a função dos linfócitos, que utilizam tanto um substrato quanto outro para a produção de energia (NEWSHOLE; CALDER, 1997). A glicose é uma ótima fonte de energia para linfócitos produzirem ATP, além de ser fonte de carbonos para síntese de outras moléculas importantes, como ácidos nucleicos e fosfolipídeos (MACIVER et al., 2008). Mas, a primeira fonte de energia utilizada por linfócitos é a glutamina, que é metabolizada na mitocôndria através do ciclo do ácido cítrico e, portanto, por fosforilação oxidativa aeróbica, enquanto que a glicose é metabolizada por glicólise anaeróbica. Concentrações inadequadas de glutamina comprometem a expressão de marcadores de superfície de linfócitos $T$ e diminuem a proporção de linfócitos $\mathrm{T} \mathrm{CD4}^{+}$e, consequentemente a razão entre $\mathrm{CD} 4^{+} / \mathrm{CD} 8^{+}$, além de prejudicar a produção de IL-2 e IFNy (CHANG et al., 1999). 
A glutamina é um L-a-aminoácido que pode ser sintetizado por todos os tecidos do organismo dos mamíferos e em todas as células pode ceder átomos de nitrogênio para a síntese de purinas, pirimidinas e aminoaçúcares. É o aminoácido livre mais abundante no plasma e musculatura esquelética, sendo também encontrada em concentrações relativamente elevadas em outros tecidos. A proliferação e desenvolvimento de células, em especial do sistema imune, o balanço acidobásico, o transporte da amônia entre os tecidos e a doação de esqueletos carbônicos para a gliconeogênese, são algumas das funções em que a glutamina está envolvida (CRUZAT et al., 2009), além de ser um substrato essencial para macrófagos e linfócitos, que a utilizam em elevadas taxas (CASTELL et al., 2004).

A glutamina endógena é sintetizada a partir de glutamato e amônia pela enzima glutamina sintetase e sua atividade é dependente de hormônios. Glicocorticóides promovem a síntese de glutamina, já o hormônio do crescimento inibe esse processo. O glutamato, por sua vez, é sintetizado a partir da desaminação dos aminoácidos de cadeia longa (BCAAs) leucina, isoleucina e valina. A adequada ativação da piruvato-desidrogenase e do ciclo do ácido tricarboxílico é necessária para prover precursores para a aminação do alfacetoglutarato, levando à síntese de glutamina. Isso sugere que a síntese desse aminoácido é dependente da utilização de substratos para a produção de energia e, consequentemente, a disponibilidade da glutamina é afetada pela chegada de nutrientes à musculatura esquelética (AGOSTINI; BIOLO, 2010). 
Figura 1 - Metabolismo da glutamina e glutamato em células de mamíferos

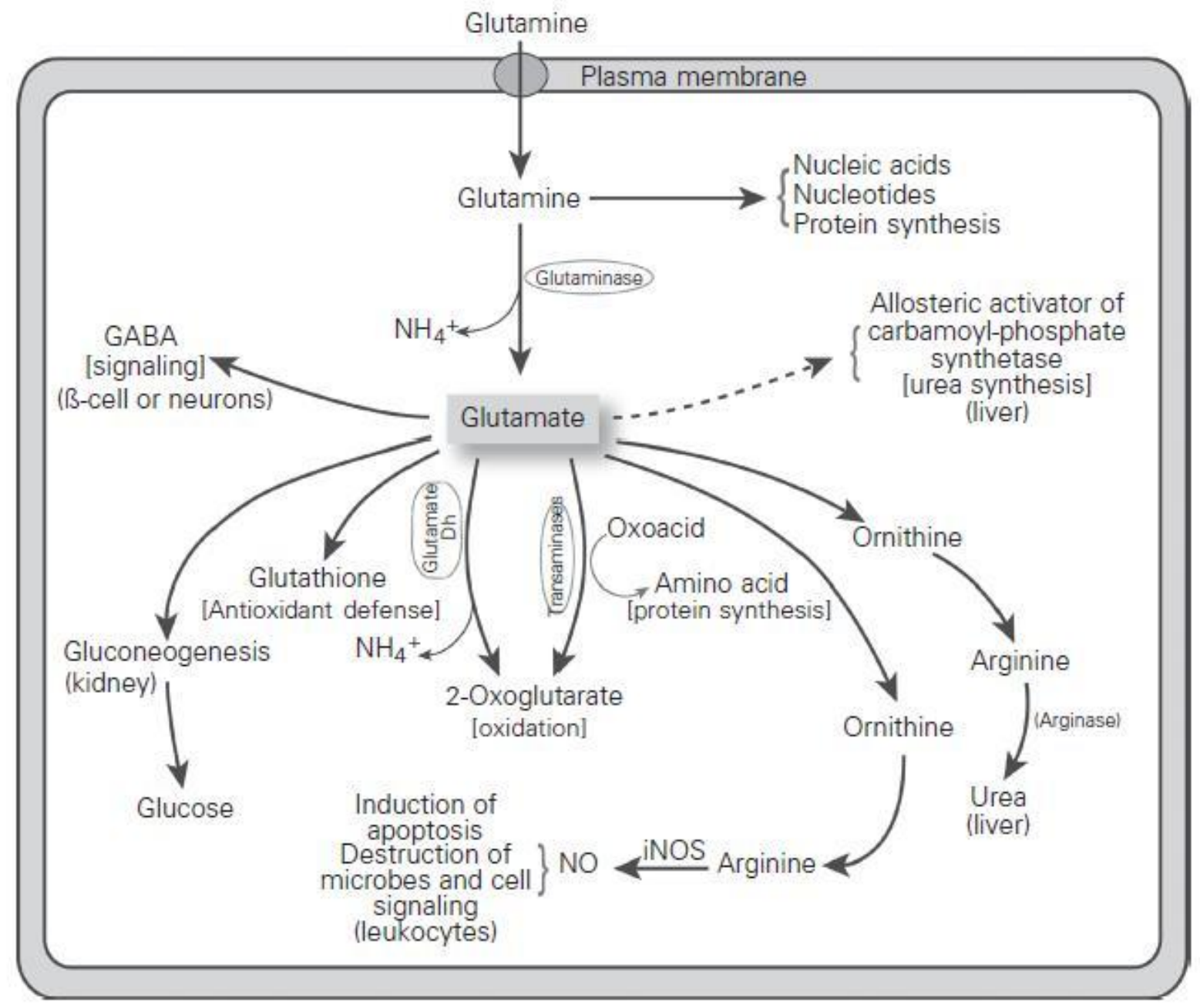

(NEWSHOLME et al., 2003)

Quantitativamente, o principal tecido de síntese, estoque e liberação de glutamina é o tecido muscular esquelético, que contém um pool de $90 \%$ da glutamina corporal. A taxa de síntese no músculo esquelético humano é de aproximadamente 50 $\mathrm{mmol} / \mathrm{h}$, sendo maior que qualquer outro aminoácido (NEWSHOLME et al., 2003). A elevada capacidade de síntese e liberação, principalmente em situações quando há aumento na sua demanda por outros órgãos e tecidos, confere ao músculo esquelético um papel metabólico essencial na regulação da glutaminemia. Eventos cirúrgicos, queimaduras e exercícios intensos e prolongados são alguns exemplos onde se observa que o consumo de glutamina excede a capacidade de síntese corporal (CRUZAT et al., 2009).

O predomínio do tipo de fibra muscular também pode influenciar a síntese de glutamina. Fibras oxidativas do tipo I podem apresentar cerca de três vezes mais 
estoques desse aminoácido quando comparadas às fibras glicolíticas tipo II. Essa diferença está relacionada com a maior atividade da glutamina sintetase e maior disponibilidade de ATP nas fibras oxidativas (RENNIE et al., 2001).

As enzimas glutaminases catalisam a deaminação por hidrólise da glutamina em íons de glutamato e amônia, que também exercem papéis cruciais no cérebro, rins e fígado. No hepatócito, a glutamina regula o ciclo da uréia, auxiliando na detoxificação da amônia e regulação do pH sistêmico (RENNIE et al., 2001).

A mitocôndria consome cerca de $90 \%$ do oxigênio inalado, tornando-se uma fonte de produção endógena de espécies reativas de oxigênio (EROS) e a glutamina exerce papel fundamental nessa geração durante a ativação dos linfócitos. Alta taxa de utilização de glutamina fornece glutamato, que age como precursor para a síntese de glutationa (GSH) intracelular. A glutamina aumenta a produção de NADPH, serve como doador de hidrogênio para a regeneração da GSH e aumenta a produção de ATP e GSH-sintase para a síntese de GSH, que protege a célula dos danos provocados pelo aumento da produção de EROS, já que o estresse oxidativo em linfócitos causa diminuição da resposta a mitógenos e antígenos (CHANG et al., 1999).

Durante o exercício aeróbico ocorre aumento do consumo de oxigênio e ativação de vias metabólicas oxidativas. A oxidação produz energia para o trabalho muscular, a manutenção das funções celulares e sua integridade. A maior parte do oxigênio consumido forma dióxido de carbono e água, porém, 1 a $2 \%$ do oxigênio não é completamente reduzido e forma espécies reativas de oxigênio, ou radicais livres (WILLIAMS et al., 2004).

A formação dos radicais livres acontece normalmente no organismo e possui funções benéficas que incluem produção de energia, inicialização da apoptose e ativação da fagocitose. Todas as células possuem sistemas de defesa antioxidantes capazes de mitigar os efeitos deletérios dessas substâncias, que estão divididos em enzimáticos e não enzimáticos. O primeiro inclui as enzimas superóxido dismutase (SOD), catalase (CAT) glutationa peroxidase (GPx). A catalase desempenha importante papel na eliminação do peróxido de hidrogênio, promovendo sua catálise até água. A GPx converte a glutationa reduzida (GSH) à glutationa oxidada (GSSG), removendo o peróxido de hidrogênio e formando água. A superóxido dismutase catalisa a dismutação do superóxido em oxigênio e peróxido de hidrogênio. Já o sistema não enzimático inclui compostos sintetizados pelo organismo como 
bilirrubina, ceruloplasmina, melatonina, coenzima $Q$, ácido úrico e outros, ingeridos através da dieta, como ácido ascórbico, tocoferóis, $\beta$-caroteno e grupos fenóis de plantas (SCHNEIDER; OLIVEIRA, 2004). Mas, quando a produção dos radicais livres excede a capacidade antioxidante celular, ocorre o estresse oxidativo, que pode provocar distúrbios musculares, fadiga, e uma série de doenças relatadas em humanos como câncer e Alzheimer (MARLIN et al., 2002).

Algumas vias potenciais de formação excessiva de radicais livres são ativadas durante o exercício físico. $O$ aumento do consumo de oxigênio pelas fibras musculares e aumento do fluxo sanguíneo resulta em extravasamento de elétrons da cadeia transportadora de elétrons da mitocôndria, ocorrendo a produção de ânions superóxido. Durante o exercício intenso, as fibras musculares podem se tornar hipóxicas e ocorrer injúria de isquemia e reperfusão. Tecidos lesionados ativam células inflamatórias, como neutrófilos que produzem radicais livres pela NADPH oxidase. O aumento da produção de catecolaminas durante o exercício provoca aumento na produção de espécies reativas de oxigênio para sua própria degradação. A hipertermia também é um possível fator para desencadear o estresse oxidativo através do aumento da oxidação da glutationa nos eritrócitos e peroxidação lipídica. A auto-oxidação da oxi-hemoglobina e meta-hemoglobina produz ânions superóxido e a formação desses compostos é aumentada durante o exercício aeróbico (DEATON; MARLIN, 2003). Se por um lado o exercício físico é uma forma de estresse, por outro, a exposição crônica, ou seja, o treinamento é capaz de produzir adaptações em resposta à maior produção desses radicais livres (SCHNEIDER; OLIVEIRA, 2004).

Fatores de transcrição sensíveis ao desequilíbrio oxidativo e vias sinalizadoras, são induzidos pelo exercício para respostas adaptativas ocorrerem. O treinamento de resistência causa como respostas expressão gênica no genoma mitocondrial da musculatura esquelética, modulando o metabolismo energético e aumentando sua biogênese e defesas antioxidantes celulares (RADAK et al., 2008).

Durante o exercício o aumento do trabalho mecânico, metabólico e fisiológico resulta em muitas alterações em diferentes órgãos. Durante o descanso, 0 organismo se recupera e compensa os efeitos estressores. Portanto, o exercício deve provocar certo nível de estresse para que adaptações ocorram. Baixas cargas de trabalho levam a níveis baixos de condicionamento físico, portanto, para atletas 
bem treinados, altas cargas de estresse são obrigatórias. Não há adaptação sem fadiga (RADAK et al., 2008).

O enduro equestre é uma modalidade basicamente aeróbica, mas os cavalos de elite estão sendo exigidos em velocidades cada vez maiores, o que torna esse esporte um potencial produtor de estresse oxidativo.

Existe uma crescente preocupação com o bem estar desses cavalos, com métodos de treinamento e suplementação, mas muito pouco se sabe sobre o que realmente acontece durante e após as provas. A literatura sobre o assunto é escassa e os dados controversos. 


\section{MATERIAIS E MÉTODOS}

\subsection{ANIMAIS}

Foram utilizados 33 cavalos das raças Puro Sangue Árabe, Anglo-Árabe e Cruza Árabe, com 400 - $450 \mathrm{~kg}$, treinados para provas de enduro, pertencentes a proprietários enduristas, alojados em centros de treinamentos e haras particulares no Estado de São Paulo.

Estes animais foram avaliados em quatro provas chanceladas pela FEI (Fédération Equestre Internationale), onde competiram nas categorias velocidade livre de $80 \mathrm{~km}$ (13 cavalos), $120 \mathrm{~km}$ (14 cavalos) e $160 \mathrm{~km}$ (6 cavalos). Animais eliminados tanto por problemas metabólicos quanto por claudicação foram descartados. Somente os cavalos que receberam aprovação na inspeção veterinária final participaram desse estudo.

Os animais receberam volumoso e concentrado comercial até 5 horas antes da largada. Todos os cavalos foram suplementados com soluções eletrolíticas durante o percurso, tiveram livre acesso a água e nas paradas obrigatórias, receberam feno de gramínea.

\subsection{SUPLEMENTAÇÃO}

Três animais de $160 \mathrm{~km}$, nove de $120 \mathrm{~km}$ e seis de $80 \mathrm{~km}$ receberam suplementação de $50 \mathrm{mg} / \mathrm{kg}$ p.v. de L-glutamina pura, via oral, conforme sugerido por Harris et al. (2006), durante um período que compreendeu 30 dias antes (-30d) e 15 dias após a prova $(+15 d)$.

Foi testada a palatabilidade antes do início da suplementação em cada animal individualmente. Todos aceitaram bem, por isso, a glutamina foi fornecida no cocho juntamente com o concentrado, uma vez por dia, na refeição da manhã, inclusive no dia da prova. 


\subsection{COLHEITA DE SANGUE E PROCESSAMENTO DAS AMOSTRAS}

As colheitas foram realizadas por punção da veia jugular, em cada momento, com tubos BD Vacutainer®, sem anticoagulante, com EDTA (ácido etilenodiaminotetracético) e com heparina sódica.

O sangue foi colhido minutos antes da prova, antes do cavalo ser encilhado, considerando-se este o momento zero ou basal (M0). Quando os cavalos completam o percurso há uma inspeção veterinária final ("vet check" final), onde ainda existe a possibilidade de eliminação por problemas metabólicos ou claudicação. Após receberem aprovação novas amostras foram coletadas, sendo considerado esse momento o M1 e após três horas, foram coletadas novas amostras, sendo esse o M2. Esses animais foram acompanhados na propriedade onde são alojados nos dias 3 (M3), 7 (M4) e 14 (M5) após a prova.

Após cada prova e cada viagem, todo o sangue foi levado ao laboratório da FMVZ - USP, para a devida separação, processamento exigido para cada análise e congelamento.

Todas as amostras foram mantidas sob refrigeração até serem levadas ao laboratório. Os tubos sem anticoagulante foram centrifugados a $5000 \mathrm{rpm}$ por 10 minutos para a obtenção do soro, que foi aliquotado e armazenado em freezer a - 80ํㅡ. O sangue dos tubos com EDTA foi utilizado para a realização do hemograma que foi feito através do contador automático BC 2800Vet (Mindray, United States) e as lâminas coradas pelo método de May-Griinwald-Giemsa modificado.

Três tubos de sangue com heparina sódica, de cada cavalo, foram centrifugados a $1800 \mathrm{rpm}$ por 10 minutos a $4^{\circ} \mathrm{C}$, o botão de leucócitos foi removido e depositado em $1 \mathrm{~mL}$ de PBS e os eritrócitos lisados 3 vezes. Os leucócitos totais foram contados, suspendidos em solução de soro fetal bovino e DMSO a $10 \%$ e congelados gradualmente $\mathrm{a}-80^{\circ} \mathrm{C}$.

O sangue dos tubos com heparina sódica foi centrifugado a 1900 x g por 15 minutos a $4^{\circ} \mathrm{C}$. As hemáceas foram ressuspendidas em solução salina tamponada (PBS) e centrifugadas novamente. Esse procedimento de lavagem foi repetido três vezes e as hemáceas acondicionadas em microtubos tipo Eppendorfs e congeladas a $-80^{\circ} \mathrm{C}$. Para as análises da catalase, as hemáceas foram armazenadas com uma 
solução de EDTA e mercaptoetanol. A determinação da concentração de hemoglobina foi realizada pelo método de Drabkin's, onde a presença desse reagente forma um composto, a cianometahemoglobina, que absorve em $540 \mathrm{\eta m}$ (absorbância).

A análise da glutamina sérica e amônia foi realizada em analisador bioquímico (Daytona $\AA$, Randox, United Kingdom). A glutamina pelo método cinético colorimétrico com kit comercial (L-glutamine GLN GM1373, Randox) e a amônia pelo método enzimático utilizando-se kit comercial (AM3979, Randox).

\subsection{VARIÁVEIS DE ESTRESSE OXIDATIVO}

Para a determinação da GSH (glutationa reduzida) eritrocitária adicionou-se 1,8 $\mathrm{mL}$ de água purificada em $200 \mu \mathrm{L}$ de sangue total e $3 \mathrm{~mL}$ de solução precipitante. Após 5 minutos de repouso, é centrifugada a $1800 \times$ g por 5 minutos. Aos $200 \mu \mathrm{L}$ do sobrenadante, adicionou-se $800 \mu \mathrm{L}$ de solução fosfato e em seguida foram adicionados $100 \mathrm{~L}$ de DTNB (5,5'-dithiobis-(2-ácido nitrobenzóico) para a imediata leitura em espectrofotômetro a 412 ๆm (absorbância).

A determinação do MDA (malondialdeído) plasmático foi realizada adicionandose $2 \mathrm{~mL}$ de solução de ácido tricloroacético (TCA) $10 \%$ a $1 \mathrm{~mL}$ de plasma e centrifugando por 15 minutos a $15^{\circ} \mathrm{C}$. A $750 \mu \mathrm{L}$ de sobrenadante foi adicionado 750 $\mu \mathrm{L}$ de ácido tiobarbitúrico $1 \%$ (TBA) e aquecido em banho de água fervente por 10 minutos. Os tubos foram resfriados em água gelada e foi feita a leitura de absorbância em espectrofotômetro a 532 ๆm.

A atividade da catalase foi mesurada de acordo com Aebi (1984) modificado, adicionado-se $20 \mu \mathrm{L}$ do hemolisado em $980 \mu \mathrm{L}$ de tampão fosfato $50 \mathrm{mmol} / \mathrm{L}$ contendo peróxido de hidrogênio $10 \mathrm{mmol} / \mathrm{L}$. A absorbância foi lida em espectrofotômetro a $240 \eta \mathrm{m}$.

A determinação da SOD (superóxido dismutase) foi realizada a partir da diluição de utilizando-se de kit comercial (Ransod kit; Randox, United Kingdom) em analisador bioquímico automático Labmax 240 (marca Labtest). 
A determinação da GPx (glutationa peroxidase) foi realizada utilizando-se kit comercial (Ransel kit; Randox, United Kingdom) e a leitura realizada em analisador bioquímico automático Labmax 240 (marca Labtest).

Para a correção dos resultados de CAT, SOD e GPx foram realizados as analises de hemoglobina das amostras congeladas.

\subsection{ENSAIO IMUNOENZIMÁTICO - ELISA}

O soro foi utilizado para as determinações das concentrações de Cortisol, $\mathrm{GH}$, interleucinas IL-2, IL-4 e IL-10 e IFNy seguindo as metodologias descritas nas bulas de cada kit comercial utilizado recomendada pelo fabricante. Para a determinação das concentrações de cortisol utilizou-se o kit multiespécie da marca Enzo (ADI-901071). Para a determinação do GH utilizou-se kit para equinos da marca USCN (E90044Eq). As interleucinas IL-2, IL-4 e IL-10 foram determinadas através dos Duosets específicos para equinos da marca R \& D Systems (DY 1613, DY1809 e DY1605, respectivamente). O IFNy foi determinado através do kit para equinos da marca Bethyl (E-77-806).

Todas as placas foram lidas na leitora EL 808 (Bio-Tek Instruments, United States).

\subsection{ESTUDO PILOTO DE CONGELAMENTO E VIABILIDADE DE LEUCÓCITOS}

Estudos a campo são complicados quanto à conservação das amostras, transporte ao laboratório e processamento. As provas mais longas de $160 \mathrm{~km}$ iniciam as 5:00 h e terminam, aproximadamente, 20:00 h. Nesse estudo, no dia da prova, o primeiro momento de coleta foi antes da largada, ou seja, aproximadamente as 4:30 h e o último, 3 horas após o término, entre $23-24 \mathrm{~h}$. Um estudo piloto foi conduzido com o intuito de averiguar a viabilidade dos leucócitos após permanecerem mais de um dia na geladeira e serem submetidos a um processo de congelamento. 
Nove tubos contendo heparina foram coletados de 15 cavalos sadios. Três amostras de cada animal foram imediatamente processadas e congeladas. Três outras amostras foram armazenadas a $4^{\circ} \mathrm{C}$ por 24 horas e as últimas três amostras, armazenadas a $4^{\circ} \mathrm{C}$ por 48 horas antes de serem processadas e congeladas. Tanto as amostras de sangue fresco quanto as de sangue armazenados em geladeira foram centrifugadas a $1800 \mathrm{rpm}$ por 10 minutos, o botão de leucócitos removido e depositado em PBS e os eritrócitos lisados três vezes. Os leucócitos totais foram contados, suspendidos em solução de FBS e DMSO a 10\% e congelados gradualmente a $-80^{\circ}$ C. Três meses depois, todas as amostras foram descongeladas e os leucócitos recontados.

Os dados foram submetidos ao teste de normalidade Kolmogorov-Smirnov e posteriormente analisados através do teste de comparação Tukey pareado. Todas as análises foram realizadas com um grau de $5 \%$ de significância $(P<0.05)$.

\subsection{IMUNOFENOTIPAGEM}

A imunofenotipagem consiste no isolamento de populações de células distintas com diferentes antígenos de superfície marcados com anticorpos fluorescentes específicos. A avaliação da intensidade da fluorescência ocorre para a detecção de antígenos de superfície diferentes marcados com anticorpos monoclonais específicos ligados a compostos químicos fluorescentes ou fluorocromos.

Os leucócitos foram descongelados rapidamente em banho-maria a $37^{\circ} \mathrm{C}$, centrifugados a $800 \mathrm{rpm}$ por 5 minutos, ressuspendidos em $1 \mathrm{~mL}$ de PBS e recontados. $1 \times 10^{6}$ células foram depositadas em $1 \mathrm{~mL}$ de PBS em cada tubo. Para cada amostra, utilizou-se 3 tubos, o primeiro como branco, o segundo para anticorpos monoclonais equinos anti CD2 (rat IgG2a anti-horse CD2, Serotec MCA1278) e CD4 (mouse IgG1 anti-horse CD4, Serotec MCA1078) e o terceiro tubo para anticorpos monoclonais equinos anti CD2 e CD8 (mouse IgG1 anti-horse CD8, Serotec MCA 2385). Após meia hora de incubação a temperatura ambiente e segunda lavagem procedeu-se a marcação com anticorpos secundários goat anti-rat IgG RPE (Serotec 303009) e goat anti-mouse IgG FITC (Serotec 103002), outra incubação de meia hora no escuro e última lavagem. As células marcadas foram 
ressuspendidas em $1 \mathrm{~mL}$ de PBS e submetidas à análise no citômetro de fluxo (BD FACS Calibur, United States) para identificação e contagem das subpopulações linfocitárias.

Os dados lidos no citômetro de fluxo foram analisados por um programa de computador (software Flow Jo), que forneceu o histograma e tabela com a quantidade de células detectadas pela imunofenotipagem.

\subsection{ANÁLISE ESTATÍSTICA}

Com o objetivo de avaliar a ocorrência de diferença estatística entre os resultados obtidos em animais que receberam ou não suplementação de L-glutamina, a prova não paramétrica $U$ de Mann-Whitney foi adotada a 0,05 de significância.

A fim de comparar os parâmetros avaliados entre os três grupos submetidos à prova de enduro de 80, 120 e $160 \mathrm{~km}$, foi conduzido o teste não paramétrico de Kruskal-Wallis $(\alpha=0,05)$. A análise post hoc foi realizada por meio de comparações múltiplas disponíveis no pacote "pgirmess" do software livre $R(\alpha=0,05)$.

Foi realizada, ainda, a comparação de todas as variáveis segundo o momento de estudo. Para tanto, o teste de Friedman foi utilizado $(\alpha=0,05)$. A análise post hoc foi realizada por meio de comparações múltiplas disponíveis no pacote "agricolae" do software livre $R(\alpha=0,05)$.

Buscando identificar possível correlação entre as variáveis de estudo, o coeficiente de correlação de Spearman foi adotado a 0,05 de significância.

Todas as provas, exceto as análises post hoc, foram realizadas com o auxílio do software SPSS v. 9.0. 


\section{RESULTADOS E DISCUSSÃO}

A média de temperatura e umidade relativa do ar (URA) foi calculada levando-se em consideração o valor mínimo e máximo durante o evento. A primeira prova realizada em junho de 2011 na cidade de Pirassununga apresentou temperatura média de $20,0^{\circ} \mathrm{C}$ e $53 \%$ de URA. A segunda, realizada em setembro de 2011 em Campinas, apresentou 23,6 - C e 56,5\% de URA. A terceira, realizada em abril de 2012 em Bragança Paulista, apresentou 18,4 $\mathrm{C}$ e 76\% de URA. A quarta, realizada em Sorocaba, apresentou $18,8^{\circ} \mathrm{C}$ e $54 \%$ de URA.

A média de velocidade que os cavalos competiram nas quatro provas foi 19,04 \pm $1,03 \mathrm{~km} / \mathrm{h}$ para $80 \mathrm{~km}, 19,27 \pm 2,27 \mathrm{~km} / \mathrm{h}$ para $120 \mathrm{~km}$ e $17,85 \pm 0,69 \mathrm{~km} / \mathrm{h}$ para 160 $\mathrm{km}$ segundo dados oficiais divulgados pela comissão organizadora dos eventos. A velocidade das provas está crescendo a cada dia e considerando que o enduro é um esporte praticado ao ar livre, onde a maioria das competições aqui no Brasil são realizadas no calor e muitas vezes, com alta umidade relativa do ar, onde há grande diversidade de relevo (o que constitui uma dificuldade), essas médias de velocidade apresentadas por esses cavalos podem ser consideradas altas.

$O$ aumento do fluxo de oxigênio para a musculatura esquelética durante 0 exercício aeróbico resulta na formação de espécies reativas de oxigênio, substâncias conhecidas simplesmente como radicais livres. A produção dessas moléculas aumenta nos exercícios de alta intensidade e extenuantes e foram relacionadas a um grande número de doenças. Por outro lado, sabe-se que a atividade física é uma conhecida forma de estresse e a exposição crônica a ela, chamada de treinamento físico, é capaz de produzir adaptações em resposta ao aumento da produção de EROS. Os radicais livres são produzidos naturalmente no organismo através de processos metabólicos oxidativos e, muitas vezes, são de extrema utilidade, como nas situações em que há necessidade de ativação do sistema imunológico (como exemplo, macrófagos utilizam peróxido de hidrogênio para destruir bactérias); na desintoxicação de drogas e na produção do óxido nítrico, fator relaxante do endotélio, extremamente importante nos processos de vasodilatação. $O$ estresse oxidativo ocorre quando um desequilíbrio entre os sistemas pró-oxidantes e antioxidantes, de maneira que os primeiros sejam predominantes. Um dos principais mecanismos de lesão é a lipoperoxidação, ou 
seja, a oxidação da camada lipídica da membrana celular. Além disso, o estresse oxidativo pode gerar danos a proteínas e ao DNA, provocando diversas alterações na função celular e, portanto, tecidual (SCHNEIDER; OLIVEIRA, 2004).

Os valores das medianas, primeiro e terceiro quartis das variáveis SOD, GPx, GSH, MDA e CAT nos cavalos que competiram em 80, 120 e 160 km, suplementados ou não com glutamina estão expressos na tabela 1 . 
Tabela 1 - Valores das medianas, primeiro e terceiro quartis das variáveis SOD, GPx, GSH, MDA e CAT nos cavalos que competiram em 80,120 e 160 km, suplementados ou não com glutamina

\begin{tabular}{|c|c|c|c|c|c|c|c|c|c|c|c|}
\hline & & SOD & (U/gHb) & GPX & (U/gHb) & GSH & $(\mu \mathrm{mol} / \mathrm{L})$ & MDA & ( $\mu \mathrm{mol} / \mathrm{L})$ & CAT & $(\mathrm{K} / \mathrm{gHb})$ \\
\hline DISTÂNCIA & $\mathbf{T}$ & NÃO SUPL & SUPL & NÃO SUPL & SUPL & NÃO SUPL & SUPL & NÃO SUPL & SUPL & NÃO SUPL & SUPL \\
\hline \multirow{6}{*}{$80 \mathrm{KM}$} & 0 & $\begin{array}{c}1834,0 \\
(1647,4-2095,4)\end{array}$ & $\begin{array}{c}2260,9 \\
(1834,0-2648,5)\end{array}$ & $\begin{array}{c}537,1 \\
(394,8-633,4)\end{array}$ & $\begin{array}{c}566,2^{*} \\
(392,6-628,5)\end{array}$ & $\begin{array}{c}28,3 \\
(24,2-31,8)\end{array}$ & $\begin{array}{c}29,4^{\mathrm{A}} \\
(24,2-33,0)\end{array}$ & $\begin{array}{c}0,32^{\mathbf{A}^{*}} \\
(0,32-0,37)\end{array}$ & $\begin{array}{c}0,32^{A^{*}} \\
(0,26-2,23)\end{array}$ & $\begin{array}{c}2157,1 \\
(2010,5-2346,1)\end{array}$ & $\begin{array}{c}2000,4 \\
(1993,4-2157,1)\end{array}$ \\
\hline & 1 & $\begin{array}{c}1934,0 \\
(1631,8-2095,4)\end{array}$ & $\begin{array}{c}2233,7 \\
(2078,4-2674,5)\end{array}$ & $\begin{array}{c}418,3^{\mathbf{A}} \\
(377,8-593,2)\end{array}$ & $\begin{array}{c}573,1 \\
(432,6-593,2)\end{array}$ & $\begin{array}{c}31,6 \\
(22,3-33,0)\end{array}$ & $\begin{array}{c}29,8^{\mathbf{A}} \\
(22,3-34,3)\end{array}$ & $\begin{array}{c}0,56^{\mathbf{B}^{*}} \\
(0,52-0,87)\end{array}$ & $\begin{array}{c}0,60^{A^{*}} \\
(0,50-2,10)\end{array}$ & $\begin{array}{c}2205,7 \\
(2103,7-2360,0)\end{array}$ & $\begin{array}{c}2288,6 \\
(2021,8-2360,3)\end{array}$ \\
\hline & 2 & $\begin{array}{c}2402,1 \\
(1017,0-2669,8)\end{array}$ & $\begin{array}{c}2488,8 \\
(2445,6-2669,8)\end{array}$ & $\begin{array}{c}460,9^{A^{*}} \\
(278,8-597,6)\end{array}$ & $\begin{array}{c}405,9^{*} \\
(357,5-597,6)\end{array}$ & $\begin{array}{c}29,3 \\
(15,6-33,1)\end{array}$ & $\begin{array}{c}21,3^{\mathbf{A}} \\
(17,5-29,2)\end{array}$ & $\begin{array}{c}0,37^{A} \\
(0,26-0,48)\end{array}$ & $\begin{array}{c}0,41^{A} \\
(0,26-2,90)\end{array}$ & $\begin{array}{c}2110,4 \\
(2076,9-2469,2)\end{array}$ & $\begin{array}{c}2092,2 \\
(2074,6-2208,1)\end{array}$ \\
\hline & 3 & $\begin{array}{c}2531,0 \\
(1014,1-3091,5)\end{array}$ & $\begin{array}{c}2528,8 \\
(2450,3-2648,6)\end{array}$ & $\begin{array}{c}259,1^{\mathbf{B}} \\
(210,0-541,8)\end{array}$ & $\begin{array}{c}432,1 \\
(322,3-548,5)\end{array}$ & $\begin{array}{c}29,5^{*} \\
(14,6-30,1)\end{array}$ & $\begin{array}{c}13,9^{\mathbf{B}^{*}} \\
(11,4-21,6)\end{array}$ & $\begin{array}{c}5,60^{\mathrm{c}} \\
(0,63-6,75)\end{array}$ & $\begin{array}{c}3,33^{\mathbf{B}} \\
(0,63-6,19)\end{array}$ & $\begin{array}{c}2237,6 \\
(2180,1-22479)\end{array}$ & $\begin{array}{c}2171,4 \\
(2022,7-2279,8)\end{array}$ \\
\hline & 4 & $\begin{array}{c}2362,0 \\
(1409,6-2831,6)\end{array}$ & $\begin{array}{c}2623,1 \\
(2362,0-3911,0)\end{array}$ & $\begin{array}{c}292,6 \\
(219,2-653,2)\end{array}$ & $\begin{array}{c}428,9 \\
(318,9-625,5)\end{array}$ & $\begin{array}{c}30,6 \\
(13,3-32,5)\end{array}$ & $\begin{array}{c}22,0^{\mathbf{A}} \\
(13,2-30,3)\end{array}$ & $\begin{array}{c}4,48^{\mathrm{C}} \\
(1,15-4,67)\end{array}$ & $\begin{array}{c}1,08^{\mathrm{C}} \\
(0,94-2,60)\end{array}$ & $\begin{array}{c}2134,0 \\
(2014,6-2574,5)\end{array}$ & $\begin{array}{c}2037,3 \\
(1924,3-2620,4)\end{array}$ \\
\hline & 5 & $\begin{array}{c}2109,2 \\
(948,3-2564,2) \\
\end{array}$ & $\begin{array}{c}2436,8 \\
(1936,4-3024,3) \\
\end{array}$ & $\begin{array}{c}320,2 \\
(264,2-481,7) \\
\end{array}$ & $\begin{array}{c}482,1 \\
(334,8-544,5) \\
\end{array}$ & $\begin{array}{c}29,5 \\
(24,3-33,0) \\
\end{array}$ & $\begin{array}{c}26,0^{\mathbf{A}} \\
(21,5-32,1) \\
\end{array}$ & $\begin{array}{c}0,46^{\mathbf{A}} \\
(0,31-0,49) \\
\end{array}$ & $\begin{array}{c}0,54 \\
(0,37-0,60) \\
\end{array}$ & $\begin{array}{c}2085,1 \\
(1805,7-2324,1) \\
\end{array}$ & $\begin{array}{c}2021,5 \\
(1805,7-2130,3) \\
\end{array}$ \\
\hline \multirow{8}{*}{$120 \mathrm{KM}$} & 0 & 2135,3 & 2245,5 & 397,1 & 556,3 & $27,9^{A}$ & $28,0^{A}$ & 0,26 & $1,73^{\mathrm{A}}$ & 2107,4 & 2010,5 \\
\hline & 0 & $(2067,4-2408,5)$ & $(2041,2-2706,6)$ & $(371,3-516,8)$ & $(445,3-608,6)$ & $(27,8-30,3)$ & $(25,6-30,7)$ & $(0,21-0,28)$ & $(0,34-1,96)$ & $(1529,9-2242,1)$ & $(1743,2-2316,0)$ \\
\hline & 1 & $\begin{array}{c}1972,6 \\
(1795,9-2131,5)\end{array}$ & $\begin{array}{c}2196,6 \\
(1770,1-2520,7)\end{array}$ & $\begin{array}{c}470,8 \\
(391,2-479,5)\end{array}$ & $\begin{array}{c}563,5 \\
(463,2-584,8)\end{array}$ & $\begin{array}{c}28,7^{\mathrm{A}} \\
(27,1-33,8)\end{array}$ & $\begin{array}{c}29,8^{\mathrm{A}} \\
(26,0-32,9)\end{array}$ & $\begin{array}{c}0,39 \\
(0,26-0,41)\end{array}$ & $\begin{array}{c}2,08^{B} \\
(0,63-2,27)\end{array}$ & $\begin{array}{c}2127,3 \\
(2110,0-2286,7)\end{array}$ & $\begin{array}{c}2091,7 \\
(2088,1-2118,7)\end{array}$ \\
\hline & 2 & $\begin{array}{c}1988,8 \\
(1979,4-2223,8)\end{array}$ & $\begin{array}{c}2301,7 \\
(2054,3-2757,6)\end{array}$ & $\begin{array}{c}426,7 \\
(405,9-456,9)\end{array}$ & $\begin{array}{c}599,3 \\
(4609-624\end{array}$ & $\begin{array}{l}27,1^{\mathrm{A}} \\
(271-318)\end{array}$ & $\begin{array}{l}27,0^{A} \\
(251-331)\end{array}$ & 0,31 & $0,69^{\mathrm{c}}$ & $\begin{array}{c}2075,0 \\
20\end{array}$ & $\begin{array}{c}2335,8 \\
(2257,1-2469,2)\end{array}$ \\
\hline & 3 & $\begin{array}{c}2362,7 \\
2,01\end{array}$ & $\begin{array}{c}2608,7 \\
2\end{array}$ & $\begin{array}{c}426,8 \\
420\end{array}$ & $\begin{array}{c}560,5 \\
560\end{array}$ & $18,8^{\mathrm{B}}$ & $\begin{array}{l}\left(20,1-3,8^{\mathbf{B}}, 1\right) \\
1\end{array}$ & $\begin{array}{c}(0,27-0,30) \\
0,26\end{array}$ & $\begin{array}{c}(0,35-2,01) \\
5,54^{\mathrm{D}}\end{array}$ & $\begin{array}{c}(2036,5-2086,0) \\
2097,6\end{array}$ & $\begin{array}{c}(225,1-2469,2) \\
2083,6\end{array}$ \\
\hline & & $\begin{array}{c}(1716,5-1658,9) \\
1716,5\end{array}$ & $\begin{array}{c}(1722,1-2667,3) \\
2587,7\end{array}$ & $\begin{array}{c}(252,2-560,2) \\
420,5\end{array}$ & $\begin{array}{c}(344,1-607,5) \\
610,6\end{array}$ & $\begin{array}{c}(16,0-25,3) \\
25,3^{\mathrm{A}}\end{array}$ & $\begin{array}{c}(12,1-27,4) \\
20,7^{A}\end{array}$ & $\begin{array}{c}(0,17-5,60) \\
1,29\end{array}$ & $\begin{array}{c}(3,06-6,19) \\
4,46^{\mathrm{D}}\end{array}$ & $\begin{array}{c}(2087,1-2145,7) \\
2042,7\end{array}$ & $\begin{array}{c}(1839,5-2243,1) \\
2134,4\end{array}$ \\
\hline & 4 & $(1658,9-2858,8)$ & $(1158,5-2970,5)$ & $(244,6-432,3)$ & $(292,6-651,2)$ & $(17,8-29,5)$ & $(19,33-30,0)$ & $(1,01-4,40)$ & $(2,31-5,00)$ & $(1869,8-3108,4)$ & $(2118,0-2144,7)$ \\
\hline & 5 & $\begin{array}{c}2561,8 \\
(1617,6-2856,6)\end{array}$ & $\begin{array}{c}2847,1 \\
(1509,8-2937,5)\end{array}$ & $\begin{array}{c}403,3 \\
(283,2-455,9)\end{array}$ & $\begin{array}{c}669,6 \\
(351,4-736,8)\end{array}$ & $\begin{array}{c}27,4^{\mathrm{A}} \\
(21,1-29,4)\end{array}$ & $\begin{array}{c}27,1^{A} \\
(21,5-32,6)\end{array}$ & $\begin{array}{c}0,66 \\
(0,37-0,73)\end{array}$ & $\begin{array}{c}0,50^{\mathrm{C}} \\
(0,42-0,69)\end{array}$ & $\begin{array}{c}2138,2 \\
(2021,5-2192,4)\end{array}$ & $\begin{array}{c}2234,5 \\
(2033,2-2395,3)\end{array}$ \\
\hline \multirow{6}{*}{$160 \mathrm{KM}$} & 0 & $\begin{array}{c}2150,9 \\
(1383,9-2918,2)\end{array}$ & $\begin{array}{c}2767,7 \\
(2552,3-2953,1)\end{array}$ & $\begin{array}{c}504,3 \\
(430,5-578,0)\end{array}$ & $\begin{array}{c}537,1 \mathbf{A} \\
(529,7-567,8)\end{array}$ & $\begin{array}{c}26,2 \\
(26,0-26,3)\end{array}$ & $\begin{array}{c}30,0 \\
(28,8-31,8)\end{array}$ & $\begin{array}{c}0,47 \\
(0,37-0,58)\end{array}$ & $\begin{array}{c}0,55 \\
(0,46-0,65)\end{array}$ & $\begin{array}{c}1944,6 \\
(1743,2-2146,0)\end{array}$ & $\begin{array}{c}1668,9 \\
(1470,9-2359,4)\end{array}$ \\
\hline & 1 & $\begin{array}{c}2447,5 \\
(2281,2-2613,8)\end{array}$ & $\begin{array}{c}2048,3 \\
(1899,4-2203,1)\end{array}$ & $\begin{array}{c}455,5 \\
(413,2-497,7)\end{array}$ & $\begin{array}{c}418,3 \mathbf{A} \\
(405,2-633,2)\end{array}$ & $\begin{array}{c}26,1 \\
(24,6-27,5)\end{array}$ & $\begin{array}{c}33,5 \\
(28,6-38,0)\end{array}$ & $\begin{array}{c}0,28 \\
(0,26-0,29)\end{array}$ & $\begin{array}{c}0,66 \\
(0,46-0,86)\end{array}$ & $\begin{array}{c}2395,6 \\
(2091,7-2699,6)\end{array}$ & $\begin{array}{c}2142,0 \\
(2103,7-2586,8)\end{array}$ \\
\hline & 2 & $\begin{array}{c}1920,3 \\
(1584,6-2256,1)\end{array}$ & $\begin{array}{c}2392,4 \\
(2265,6-2402,1)\end{array}$ & $\begin{array}{c}482,8 \\
(452,9-512,7)\end{array}$ & $\begin{array}{c}493,7 \mathbf{A} \\
(480,8-562,4)\end{array}$ & $\begin{array}{c}23,3 \\
(20,1-26,4)\end{array}$ & $\begin{array}{c}(2,0)(3,0) \\
32,3 \\
(27,0-37,5)\end{array}$ & $\begin{array}{c}0,26 \\
(0,19-0,33)\end{array}$ & $\begin{array}{c}(0,40,33 \\
0,00) \\
(0,22-0,48)\end{array}$ & $\begin{array}{c}2367,5 \\
(2189,5-2545,5)\end{array}$ & $\begin{array}{c}2259,5 \\
(2101,2-2274,0)\end{array}$ \\
\hline & 3 & $\begin{array}{c}1974,2 \\
(1524,2-2424,2)\end{array}$ & $\begin{array}{c}1449,5 \\
(1372,0-3091,5)\end{array}$ & $\begin{array}{c}439,5 \\
(237,0-641,9)\end{array}$ & $\begin{array}{c}279,1 \mathbf{B} \\
(259,1-513,4)\end{array}$ & $\begin{array}{c}25,1 \\
(20,1-30,0)\end{array}$ & $\begin{array}{c}29,8 \\
(18,9-30,0)\end{array}$ & $\begin{array}{c}2,37 \\
(0,19-4,54)\end{array}$ & $\begin{array}{c}7,02 \\
(0,28-7,33)\end{array}$ & $\begin{array}{c}2156,6 \\
(2083,6-2229,5)\end{array}$ & $\begin{array}{c}1922,6 \\
(820,9-2230,8)\end{array}$ \\
\hline & 4 & $\begin{array}{c}1831,6 \\
(1592,8-2071,1)\end{array}$ & $\begin{array}{c}1808,5 \\
12570-3373\end{array}$ & $\begin{array}{c}422,6 \\
(4174-4278)\end{array}$ & $318,0 \mathrm{C}$ & 20,5 & 32,5 & 3,34 & 4,67 & $\begin{array}{c}1993,8 \\
19\end{array}$ & 2108,2 \\
\hline & 5 & $\begin{array}{c}1797,5 \\
(1759,6-1835,4)\end{array}$ & $\begin{array}{c}1491,2 \\
(1395,3-2564,2)\end{array}$ & $\begin{array}{c}(41,4-427,8) \\
520,4 \\
(457,4-583,4)\end{array}$ & $\begin{array}{c}394,0 \mathrm{C} \\
(320,2-514,6)\end{array}$ & $\begin{array}{c}(16,9-0 \\
24,0 \\
(21,1-27,0)\end{array}$ & $\begin{array}{c}(16,4-31,1,1) \\
31,1 \\
(13,9-34,8)\end{array}$ & $\begin{array}{c}(0,98-3, / 1) \\
0,49 \\
(0,35-0,63)\end{array}$ & $\begin{array}{c}0,69 \\
0,89) \\
(0,40-0,97)\end{array}$ & $\begin{array}{c}(1707,9-2279,6) \\
2146,5 \\
(\mathbf{2 0 3 3}, \mathbf{2}-\mathbf{2 2 5 3 , 5})\end{array}$ & $\begin{array}{c}(1946,5-3563,2) \\
\mathbf{2 1 0 0 , 9} \\
(\mathbf{2 0 5 6 , 1 - 2 3 1 9 , 8 )}\end{array}$ \\
\hline
\end{tabular}

Letras maiúsculas na mesma coluna indicam diferença $(p<0,05)$ entre os momentos. * na mesma linha indica diferença $(p<0,05)$ quanto à suplementação com glutamina no mesmo momento. 
Algum grau de fadiga, na qual a produção de EROS desempenha papel importante, é esperada após provas de longa distância. Enquanto que o exercício regular é benéfico para a saúde, sessões agudas de exercício intenso podem induzir estresse oxidativo. Kinnunen et al. (2005) demonstraram que a proteção antioxidante dependente da glutationa na musculatura esquelética é fortemente influenciada pelo treinamento de resistência e que níveis basais de antioxidantes.

As enzimas antioxidantes mais importantes são a superóxido dismutase (SOD), a catalase (CAT) e a glutationa peroxidase (GPx). A SOD possui atividade catalítica que permite a transformação de ânions superóxido em peróxido de hidrogênio e água, inativando assim, os oxidantes (KIRSCHVINK et al., 2008). A CAT promove a catálise do peróxido de hidrogênio até água. A GPx converte a glutationa reduzida (GSH) à glutationa oxidada (GSSG), removendo o peróxido de hidrogênio e formando água. Dessa forma, tanto a CAT quanto a GPx evitam o acúmulo de radical superóxido e do peróxido de hidrogênio para que não haja produção do radical hidroxil, contra o qual não existe sistema enzimático de defesa (SCHNEIDER; OLIVEIRA, 2004). A GSH é um dos antioxidantes endógenos mais importantes, existente tanto no citosol, quanto na mitocôndria. O fígado é o responsável por sua síntese que supre 90 \% da GSH circulante e exporta GSH para o plasma durante exercícios prolongados (SUN et al., 2010).

A SOD e a CAT não apresentaram nenhuma alteração significativa em relação à distância percorrida, momentos de coleta e nem quanto à suplementação com glutamina. Teixeira Neto (2006) avaliou cavalos de enduro e também não encontrou alteração na atividade da catalase. É sabido que o treinamento aumenta os níveis das enzimas antioxidantes, como um mecanismo de defesa aos desafios oxidativos (VINA et al., 2006). Todos os cavalos que participaram desse estudo são treinados há, no mínimo 2 anos, já que existe obrigatoriedade quanto à graduação dos animais de velocidade livre. Portanto, mesmo correndo em altas velocidades, a atividade das enzimas antioxidantes foi suficiente para não permitir que houvesse estresse oxidativo.

Os cavalos de 160 km não apresentaram nenhuma alteração nos níveis de GSH, porém, nos cavalos de $120 \mathrm{~km}$ houve uma acentuada diminuição três dias após a prova, tanto nos animais suplementados, quanto nos não suplementados. Nos cavalos de $80 \mathrm{~km}$ que receberam suplementação, não houve alteração significativa 
em nenhum momento, porém, nos suplementados, houve diminuição em M3, exatamente como ocorreu nos de $120 \mathrm{~km}$.

Balogh et al. (2001) trabalharam com cavalos de enduro em prova de $140 \mathrm{~km} e$ perceberam que a GSH eritrocitária não diminuiu imediatamente após a prova, mas sim em 24 horas. Resultados semelhantes foram encontrados por Hargreaves et al. (2002 a) que estudaram cavalos de 80 e 160 km, Hargreaves et al. (2002 b) que estudaram cavalos em provas de $80 \mathrm{~km}$ e Marlin et al. (2002) que estudaram cavalos em provas de $140 \mathrm{~km}$. Em humanos, redução nos níveis de GSH eritrocitária tem sido observada após meias maratonas, mas não imediatamente após exercício exaustivo, somente dentro de algumas horas, provavelmente por efeito da estimulação adrenérgica durante e após o exercício que diminui a síntese hepática de GSH (SASTRE et al., 1992).

A atividade da GPx mostrou-se diminuída após 3, 7 e até 14 dias após a prova nos cavalos de 80 que não receberam suplementação e 3 dias após a prova nos cavalos de $160 \mathrm{~km}$ suplementados. A atividade da GPx é um componente chave para a homeostase da glutationa, protegendo a célula contra a peroxidação lipídica. Os cavalos de $80 \mathrm{~km}$ também tiveram um aumento em MDA três e sete dias após a prova tanto nos animais sem suplementação quanto nos suplementados. Um dos principais e mais conhecidos produtos da peroxidação lipídica é o malondialdeído, que serve como confiável marcador de peroxidação lipídica de membrana celular. Talvez, pelo fato dos cavalos de $80 \mathrm{~km}$ serem menos experientes, ou seja, possuam menor tempo de trabalho e participação em provas fortes, tenha ocorrido algum grau de lesão muscular. Esses cavalos encontram-se num período de transição entre as provas de regularidade (baixa intensidade) e as de longa distância. Provavelmente, os sistemas antioxidantes tenham sido menos eficientes, pois houve peroxidação lipídica, mas ainda sem sinais de estresse oxidativo, já que as outras enzimas não sofreram alterações importantes.

Os cavalos de $80 \mathrm{~km}$ que receberam suplementação com glutamina apresentaram menor aumento de MDA e não apresentaram alteração em GPx e GSH no período pós prova. A glutationa é um tripeptídeo sintetizado a partir do glutamato, cisteína e glicina via enzimas citosólicas glutamato cisteína ligase (GCL) e glutationa sintetase (GS). A glutamina é hidrolisada em glutamato pela glutaminase eritrocitária, produzindo amônio $\left(\mathrm{NH}^{+}\right)$como subproduto, sendo assim, importante fonte de glutamato. A concentração plasmática de substratos, a taxa de 
transporte através da membrana eritrocitária e a conversão enzimática do glutamato determinam a síntese de GSH (WILLIER et al., 2011).

A glutamina $\left(\mathrm{C}_{5} \mathrm{H}_{10} \mathrm{~N}_{2} \mathrm{O}_{3}\right)$ é um L- $\alpha$-aminoácido, tem peso molecular de aproximadamente $146,15 \mathrm{kda}$ e pode ser sintetizada por todos os tecidos do organismo, sendo o aminoácido livre mais abundante principalmente no plasma e tecido muscular esquelético. A proliferação e desenvolvimento de células, em especial do sistema imune, o balanço acidobásico, o transporte da amônia entre os tecidos e a doação de esqueletos carbônicos para a gliconeogênese, são algumas das funções em que a glutamina está envolvida (CRUZAT et al., 2009). A Lglutamina é um precursor importante da síntese de proteínas, aminoácidos, purinas e pirimidinas, ácido nucleico e é também fonte de carbono para oxidação em algumas células. $O$ produto imediato do metabolismo da glutamina na maioria das células é o L-glutamato, que é produzido pela ação da glutaminase, enzima encontrada em grande quantidade nas mitocôndrias das células que utilizam glutamina como fonte de energia. O aminoácido intracelular mais abundante é o Lglutamato e não tem a capacidade de transpor a membrana celular, necessitando de um transportador, ao passo que a L-glutamina é o extracelular encontrado em maior quantidade e entra com facilidade nas células. Dentro da célula o glutamato pode ser convertido em ácido $y$-amino butírico (GABA), ornitina, glicose ou glutationa, assim como pode doar grupo amina para a síntese de novos aminoácidos (transaminação). Em alguns tecidos como fígado, musculatura esquelética ou astrócitos, glutamato e $\mathrm{NH} 4+$ podem se combinar, pela ação da glutamina sintase para produzir glutamina, que será exportada para fora da célula (NEWSHOLME et al., 2003).

O transporte da glutamina para o meio intracelular promove elevação da captação de sódio, alterando o volume da célula. $O$ aumento no volume celular pode ser considerado um sinal anabólico, uma vez que altera favoravelmente o turnover proteico, promovendo a síntese proteica e aumentando a disponibilidade de substratos para diversos sistemas envolvidos no processo de reparação e recuperação tecidual (CRUZAT et al., 2009). Varnier et al. (1995) observaram que a administração parenteral de glutamina, após exercício de alta intensidade, promoveu o aumento dos estoques de glicogênio muscular, fato que pôde beneficiar a recuperação da lesão induzida pelo exercício exaustivo. 
O exercício provoca mudanças na utilização de substratos energéticos, sensibilidade à insulina, turnover proteico e afeta a disponibilidade de aminoácidos ligados ao metabolismo energético (AGOSTINI; BIOLO, 2010). Diferentes tipos de exercício afetam de modo diferente a produção de glutamina pela musculatura esquelética. $O$ enduro, exercício intenso e prolongado, produz um efeito negativo na concentração plasmática de glutamina maior que exercícios curtos. Isso se deve ao aumento da sua contribuição para processos como a gliconeogênese e ativação das células do sistema imunológico. Estudos sobre acompanhamento de atletas humanos após esforço intenso confirmam haver depleção dos níveis séricos e em fibras musculares do tipo I, de glutamina por 1 a 2 semanas após o exercício (KARGOTISH et al., 2005; AGOSTINI; BIOLO, 2010). Ao contrário dos exercícios extenuantes, sessões de exercício aeróbico moderado normalmente não causam significante diminuição dos níveis sanguíneos de glutamina, porém, um adequado programa de treinamento pode aumentar os níveis séricos em repouso, o que reflete um aumento da disponibilidade (KARGOTISH et al., 2007).

A suplementação com L-glutamina tem sido amplamente utilizada em humanos administrada de forma parenteral em casos de doenças como câncer, HIV, queimaduras e em pós-cirúrgicos, principalmente gastrointestinais. Também é bastante utilizada em atletas de resistência administrada oralmente. Déchelotte et al. (1991) verificaram que, no estado pós-absortivo, a suplementação oral com glutamina em indivíduos saudáveis e sedentários promoveu aumento na concentração de glutamina e glutamato plasmáticos. Em atletas em estado de repouso, Castell e Newsholme (1997) observaram que a concentração plasmática de glutamina aumentou cerca de 30 minutos após a ingestão oral de uma solução com L-glutamina (100 mg/kg de peso corporal), e retornou aos valores basais no decorrer de 2 horas. Em indivíduos fisicamente ativos, Bowtell et al. (1999) verificaram o efeito da suplementação oral com L-glutamina sobre a glutaminemia e os estoques de glicogênio muscular, após sessão de exercício intenso de corrida. A suplementação (8 g de glutamina em $330 \mathrm{~mL}$ de água) aumentou a concentração plasmática de glutamina no período de recuperação em $46 \%$. Em um estudo com porcos, Arnaud et al. (2004), avaliaram a digestibilidade aparente da glutamina em diferentes segmentos do intestino delgado e constataram que é absorvida em maior quantidade no jejuno e a digestibilidade foi de $75 \%$ do ingerido via oral. 
Harris et al. (2006), testaram diferentes doses de suplementação oral de glutamina em equinos saudáveis e concluíram que a dose de $60 \mathrm{mg} / \mathrm{kg}$ de peso vivo produziu aumento das concentrações séricas de glutamina alguma horas depois, sem aumentar os níveis de amônia e sem provocar nenhum outro efeito colateral. A partir desses dados, foi estabelecida a dose utilizada nesse estudo.

Tabela 2 - Valores da mediana, primeiro e terceiro quartis de glutamina e amônia séricas nos cavalos que competiram em 80, 120 e 160 km, suplementados ou não com glutamina

\begin{tabular}{|c|c|c|c|c|c|}
\hline & & GLUTAMINA & (mmol/L) & AMÔNIA & (mmol/L) \\
\hline DISTÂNCIA & $\mathbf{T}$ & NÃO SUPL & SUPL & NÃO SUPL & SUPL \\
\hline \multirow{6}{*}{$80 \mathrm{KM}$} & 0 & $\begin{array}{c}1,87 \\
(1,75-2,10)\end{array}$ & $\begin{array}{c}1,77 \\
(0,89-2,50)\end{array}$ & \multirow{6}{*}{$\begin{array}{c}100,17^{A} \\
(72,51-127,20) \\
177,63^{\mathbf{B}} \\
(152,51-187,58) \\
120,12^{\mathbf{C}} \\
(88,29-152,44) \\
87,25^{\mathbf{A}} \\
(73,56-99,98) \\
94,62^{\mathbf{A}} \\
(81,63-111,03) \\
89,89^{\mathbf{A}} \\
(83,59-107,40)\end{array}$} & \multirow{6}{*}{$\begin{array}{c}93,28^{A} \\
(85,30-120,56) \\
169,28^{\mathbf{B}} \\
(157,90-179,97) \\
113,54^{C} \\
(76,39-152,44) \\
87,07^{\mathbf{A}} \\
(86,28-98,94) \\
98,00^{\mathbf{A}} \\
(87,56-103,56) \\
87,53^{\mathbf{A}} \\
(85,76-90,79)\end{array}$} \\
\hline & 1 & $\begin{array}{c}1,43 \\
(1,30-2,89)\end{array}$ & $\begin{array}{c}1,93 \\
(1,15-2,13)\end{array}$ & & \\
\hline & 2 & $\begin{array}{c}1,70 \\
(1,11-1,76)\end{array}$ & $\begin{array}{c}1,39 \\
(1,17-1,68)\end{array}$ & & \\
\hline & 3 & $\begin{array}{c}1,70 \\
(1,56-1,88)\end{array}$ & $\begin{array}{c}1,51 \\
(0,41-2,00)\end{array}$ & & \\
\hline & 4 & $\begin{array}{c}1,89 \\
(1,02-1,93)\end{array}$ & $\begin{array}{c}1,78 \\
(1,10-2,52)\end{array}$ & & \\
\hline & 5 & $\begin{array}{c}1,57 \\
(1,43-2,15)\end{array}$ & $\begin{array}{c}1,91 \\
(0,68-2,34)\end{array}$ & & \\
\hline \multirow{6}{*}{$120 \mathrm{KM}$} & 0 & $\begin{array}{c}2,17 \\
(1,43-2,33)\end{array}$ & $\begin{array}{c}1,70 \\
(1,23-2,34)\end{array}$ & \multirow{6}{*}{$\begin{array}{c}89,79^{A} \\
(77,23-127,39) \\
140,18^{\mathbf{B}^{\times}} \\
(127,99-152,13) \\
98,54^{\mathbf{C}^{\times}} \\
(95,45-98,54) \\
95,30^{\mathbf{C}} \\
(88,84-102,62) \\
78,69^{\mathbf{D}} \\
(67,91-80,51) \\
83,17^{\mathbf{C}} \\
(78,45-86,42)\end{array}$} & \multirow{6}{*}{$\begin{array}{c}91,16^{\mathbf{A}} \\
(76,22-96,84) \\
165,04^{\mathbf{B}^{\star}} \\
(144,02-173,96) \\
113,95^{\mathbf{A}^{\star}} \\
(86,09-133,66) \\
88,79^{\mathbf{A}} \\
(84,83-121,19) \\
70,78^{\mathbf{A}} \\
(66,98-76,45) \\
61,16^{\mathbf{C}} \\
(56,76-65,26)\end{array}$} \\
\hline & 1 & $\begin{array}{c}2,13 \\
(1,33-2,31)\end{array}$ & $\begin{array}{c}1,89 \\
(1,21-2,32)\end{array}$ & & \\
\hline & 2 & $\begin{array}{c}1,40 \\
(1,17-1,71)\end{array}$ & $\begin{array}{c}1,23 \\
(1,06-1,70)\end{array}$ & & \\
\hline & 3 & $\begin{array}{c}1,23 \\
(1,15-1,56)\end{array}$ & $\begin{array}{c}1,43 \\
(0,73-1,77)\end{array}$ & & \\
\hline & 4 & $\begin{array}{c}1,39 \\
(1,10-1,89)\end{array}$ & $\begin{array}{c}1,70 \\
(1,34-2,12)\end{array}$ & & \\
\hline & 5 & $\begin{array}{c}1,62 \\
(1,23-1,98) \\
\end{array}$ & $\begin{array}{c}1,39 \\
(1,02-2,31) \\
\end{array}$ & & \\
\hline \multirow{6}{*}{$160 \mathrm{KM}$} & 0 & $\begin{array}{c}1,38 \\
(1,22-1,54)\end{array}$ & $\begin{array}{c}1,77 \\
(1,20-2,54)\end{array}$ & \multirow{6}{*}{$\begin{array}{c}103,87^{A} \\
(77,00-130,73) \\
85,20^{B^{\star}} \\
(64,77-105,63) \\
85,88^{B} \\
(75,97-95,79) \\
69,69^{C} \\
(69,29-70,09) \\
75,28^{B} \\
(52,98-97,57) \\
58,93^{\mathbf{D}} \\
(49,61-69,24)\end{array}$} & \multirow{6}{*}{$\begin{array}{c}155,79^{A} \\
(126,24-160,00) \\
181,98^{\mathbf{B}} \\
(178,65-193,57) \\
87,54^{\mathbf{C}} \\
(78,87-141,63) \\
80,44^{C} \\
(68,63-92,96) \\
61,44^{\mathbf{D}} \\
(60,62-109,86) \\
65,87^{\mathbf{D}}(54,91- \\
81,43)\end{array}$} \\
\hline & 1 & $\begin{array}{c}1,22 \\
(1,11-1,34)\end{array}$ & $\begin{array}{c}1,81 \\
(1,67-2,77)\end{array}$ & & \\
\hline & 2 & $\begin{array}{c}1,58 \\
(1,02-2,13)\end{array}$ & $\begin{array}{c}2,31 \\
(1,74-2,61)\end{array}$ & & \\
\hline & 3 & $\begin{array}{c}2,39 \\
(2,16-2,62)\end{array}$ & $\begin{array}{c}2,04 \\
(0,88-2,72)\end{array}$ & & \\
\hline & 4 & $\begin{array}{c}1,89 \\
(1,83-1,95)\end{array}$ & $\begin{array}{c}1,52 \\
(1,21-1,54)\end{array}$ & & \\
\hline & 5 & $\begin{array}{c}1,59 \\
(0,80-2,38)\end{array}$ & $\begin{array}{c}1,06 \\
(0,99-1,50)\end{array}$ & & \\
\hline
\end{tabular}

Letras maiúsculas na mesma coluna indicam diferença $(p<0,05)$ entre os momentos. * na mesma linha indica diferença $(p<0,05)$ quanto à suplementação com glutamina no mesmo momento.

Os valores das medianas, primeiro e terceiro quartis das variáveis glutamina e amônia nos cavalos que competiram em 80, 120 e 160 km, suplementados ou não com glutamina expressos na tabela 2 mostraram que não houve diferença nos valores de glutamina sérica entre os momentos de coleta, entre as distâncias 
percorridas, nem entre animais suplementados ou não $(p>0,05)$. A concentração de glutamina no sangue é consequência do balanço entre a síntese a partir do glutamato e amônia numa reação dependente de ATP e da sua liberação e utilização por vários órgãos como rins, fígado, coração, cérebro e musculatura esquelética (SANTOS et al., 2007). A musculatura esquelética é um grande reservatório de glutamina, e o treinamento de resistência aumenta a taxa de síntese e liberação, porém, de forma balanceada (KARGOTICH et al., 2007). Isso pode explicar não ter havido diferença nesse estudo, já que os cavalos testados foram atletas saudáveis e treinados. Muitos estudos demonstraram diminuição acentuada nos níveis de glutamina no sangue após exercícios exaustivos tanto em humanos quanto em animais (WALSH et al., 1998; BASSIT et al., 2000; CUNHA et al., 2004), predispondo assim ao desenvolvimento de doenças do trato respiratório e na síndrome overtraining (BASSIT el al., 2000; CASTELL, 2003). Talvez, a mensuração da taxa de glutamina/glutamato fosse um método mais eficiente que somente a avaliação da glutamina.

Os níveis de amônia no sangue também refletem o equilíbrio entre a produção e a remoção. O exercício intenso eleva muito esses níveis, pois há aumento do catabolismo dos aminoácidos de cadeia longa (BCAAs) e deaminação da adenosina monofosfato (AMP). A deaminação do AMP, responsável por manter a relação ATP/ADP, tem como produto final a iosina monofosfato (IMP) e amônia, que é liberada na corrente sanguínea. Há evidências que a atividade da enzima AMP deaminase é dependente da intensidade do esforço e da taxa de hidrólise do ATP, que é relativa à capacidade aeróbica das fibras musculares. Capacidade aeróbica reduzida conduz à isquemia muscular com consequente aumento da deaminação do AMP e hiperamonemia. Por outro lado, o treinamento aumenta a capacidade aeróbica dos músculos, tendo como consequência a diminuição da produção de amônia (YUAN; CHAN, 2000). A remoção da amônia do sangue é de fundamental importância, pois o acúmulo leva ao prejuízo das funções motoras e sistema nervoso central.

Durante o exercício os tecidos adiposo e muscular, ricos em enzima glutamina sintase, são os maiores responsáveis pela remoção da amônia e a utilizam, juntamente com o glutamato, para produzir glutamina (ESBJÖRNSSON et al., 2004). Houve aumento dos níveis de amônia logo após a prova em todas as categorias com e sem suplemento, porém, nas categorias de 80 e 120km, 3 horas após a prova 
ainda houve essa alteração que já não foi vista nos cavalos de $160 \mathrm{~km}$. Os cavalos de 120 e 160 km que receberam suplementação apresentaram níveis basais mais altos em relação aos que não receberam o que pode significar que esses animais com a musculatura e metabolismo mais treinados tenham tido um melhor aproveitamento e disponibilidade da glutamina suplementada.

A glutamina sintetase é a enzima chave para a produção de glutamina e para a regulação do metabolismo celular do nitrogênio. É uma aminotransferase amplamente distribuída nos tecidos e sua atividade é regulada por hormônios tais como glicocorticoides, tireoidianos, hormônio do crescimento e insulina (CRUZAT et al., 2009).

Os hormônios são particularmente importantes para a mobilização e utilização de substratos energéticos, como carboidratos e gorduras tanto intracelulares (glicogênio e triglicerídeos) como de estoques periféricos (glicogênio hepático e gordura do tecido adiposo).

Durante o exercício, com a finalidade de melhorar a chegada do oxigênio nos músculos esqueléticos, dois sistemas de luta e fuga ou de estresse são ativados, o sistema nervoso simpático e 0 eixo hipotalâmico-pituitário-adrenal. As catecolaminas, via receptores $\beta$-adrenérgicos, promovem a quebra do glicogênio muscular e hepático, aumenta a lipólise no tecido adiposo e inibe a secreção de insulina. Com isso, há um aumento das concentrações de ácidos graxos não esterificados e glicose no sangue, aumentando assim a disponibilidade desses substratos para o músculo (HYYPPÄ, 2005). A glândula pituitária aumenta a produção e liberação do hormônio corticotrófico (ACTH), que por sua vez, estimula a glândula adrenal a aumentar a síntese de cortisol e receptores de proteínas de baixo peso molecular (LDL).

O cortisol estimula a mobilização de substratos, aumentando a gliconeogênese e mobilização de ácidos graxos livres. Ao mesmo tempo, diminui a utilização de glicose em alguns tecidos para poupar esse substrato para o sistema nervoso central. Outro objetivo desse estado catabólico é criar um pool de aminoácidos livres. Durante o exercício, aminoácidos de cadeia ramificada e outros com potencial gliconeogênicos podem ser utilizados como fonte adicional de energia quando os níveis de glicose começam a cair. Outra importante ação do cortisol durante o exercício é a indução de enzimas para a síntese de catecolaminas. Além disso, o 
cortisol modula a função das células do sistema imune, agindo como agente antiinflamatório e suprimindo reações imunológicas (GRAAF-ROELFSEMA et al., 2007).

O hormônio do crescimento $(\mathrm{GH})$, também chamado de somatotropina é secretado em pulsos pela porção anterior da glândula pituitária. A maioria dos suas ações é realizada através de intermediários, chamadas de somatomedinas ou fatores de crescimento semelhantes à insulina (IGF) (HYYPPÄ, 2005). O GH promove crescimento em quase todos os tecidos através do aumento do tamanho das células e da mitose. Também aumenta a utilização de aminoácidos e síntese proteica nas células de defesa (GRAAF-ROELFSEMA et al., 2007).

Os valores das medianas, primeiro e terceiro quartis das variáveis cortisol e $\mathrm{GH}$ nos cavalos que competiram em 80, 120 e 160 km, suplementados ou não com glutamina estão expressos na tabela 3 . 
Tabela 3 - Valores da mediana, primeiro e terceiro quartis de cortisol e hormônio do crescimento (GH) nos cavalos que competiram em 80, 120 e $160 \mathrm{~km}$, suplementados ou não com glutamina

\begin{tabular}{|c|c|c|c|c|c|}
\hline & & CORTISOL & (pg/mL) & GH & $\mathrm{g} / \mathrm{mL})$ \\
\hline DISTÂNCIA & $\mathbf{T}$ & NÃO SUPL & SUPL & NÃO SUPL & SUPL \\
\hline \multirow{6}{*}{$80 \mathrm{KM}$} & 0 & $\begin{array}{c}1332,87^{A} \\
(1165,98-1732,03)\end{array}$ & $\begin{array}{c}1490,49^{A} \\
(1106,46-1732,03)\end{array}$ & $\begin{array}{c}2,82 \\
(2,02-3,50)\end{array}$ & $\begin{array}{c}2,31 \\
(1,99-2,68)\end{array}$ \\
\hline & 1 & $\begin{array}{c}9865,63^{B *} \\
(4822,97-9865,63)\end{array}$ & $\begin{array}{c}4327,68^{B} \text { * } \\
(2380,11-7133,49)\end{array}$ & $\begin{array}{c}2,49 \\
(2,04-3,52)\end{array}$ & $\begin{array}{c}2,38 \\
(2,30-2,68)\end{array}$ \\
\hline & 2 & $\begin{array}{c}3202,44 \\
(1354,30-4403,89)\end{array}$ & $\begin{array}{c}761,88^{C} \\
(465,38-1866,90)\end{array}$ & $\begin{array}{c}2,08 \\
(1,66-3,27)\end{array}$ & $\begin{array}{c}2,61 \\
(2,20-2,93)\end{array}$ \\
\hline & 3 & $\begin{array}{c}432,06^{D} \\
(149,07-2723,48)\end{array}$ & $\begin{array}{c}670,76 \\
(250,90-1654,13)\end{array}$ & $\begin{array}{c}2,25 \\
(1,91-3,02)\end{array}$ & $\begin{array}{c}2,26 \\
(2,08-2,78)\end{array}$ \\
\hline & 4 & $\begin{array}{c}892,76^{\circ} \\
(453,57-1108,52)\end{array}$ & $\begin{array}{c}862,77^{C} \\
(411,38-988,28)\end{array}$ & $\begin{array}{c}2,86 \\
(2,52-2,98)\end{array}$ & $\begin{array}{c}3,34 \\
(2,87-3,55)\end{array}$ \\
\hline & 5 & $\begin{array}{c}504,03^{\mathrm{D}} \\
(338,99-1019,09)\end{array}$ & $\begin{array}{c}572,95^{c} \\
(453,57-973,50)\end{array}$ & $\begin{array}{c}2,50 \\
(1,73-3,17)\end{array}$ & $\begin{array}{c}2,54 \\
(2,09-2,90)\end{array}$ \\
\hline \multirow{6}{*}{120 KM } & 0 & $\begin{array}{c}1850,84^{A} \\
(1231,88-2137,03)\end{array}$ & $\begin{array}{c}1783,48^{A} \\
(1219,11-2522,49)\end{array}$ & $\begin{array}{c}2,27 \\
(1,80-2,68)\end{array}$ & $\begin{array}{c}2,25 \\
(1,92-2,68)\end{array}$ \\
\hline & 1 & $\begin{array}{c}8072,62 \\
(5056,12-8654,99)\end{array}$ & $\begin{array}{c}8747,25^{\mathrm{B}} \\
(6845,32-10492,20)\end{array}$ & $\begin{array}{c}2,58 \\
(2,51-2,60)\end{array}$ & $\begin{array}{c}2,21 \\
(1,93-2,40)\end{array}$ \\
\hline & 2 & $\begin{array}{c}2044,54^{\mathbf{A}} \\
(1161,22-7463,28)\end{array}$ & $\begin{array}{c}2401,96{ }^{C} \\
(1035,09-2976,98)\end{array}$ & $\begin{array}{c}2,08 \\
(1,87-2,96)\end{array}$ & $\begin{array}{c}2,24 \\
(2,10-2,43)\end{array}$ \\
\hline & 3 & $\begin{array}{c}360,05 \\
(274,96-1086,26)\end{array}$ & $\begin{array}{c}486,12^{D} \\
(388,72-1509,12)\end{array}$ & $\begin{array}{c}2,57 \\
(2,12-2,59)\end{array}$ & $\begin{array}{c}2,28 \\
(2,16-2,45)\end{array}$ \\
\hline & 4 & $\begin{array}{c}674,89^{\mathrm{C}} \\
(403,00-1854,30)\end{array}$ & $\begin{array}{c}954,55^{\mathbf{D}} \\
(493,45-1103,49)\end{array}$ & $\begin{array}{c}2,47 \\
(2,31-3,05)\end{array}$ & $\begin{array}{c}2,52 \\
(2,12-3,12)\end{array}$ \\
\hline & 5 & $\begin{array}{c}372,89^{\mathrm{C}} \\
(353,17-1081,21) \\
\end{array}$ & $\begin{array}{c}793,27^{\mathbf{D}} \\
(472,44-950,04) \\
\end{array}$ & $\begin{array}{c}2,76 \\
(2,10-2,84) \\
\end{array}$ & $\begin{array}{c}2,48 \\
(2,06-2,89) \\
\end{array}$ \\
\hline \multirow{6}{*}{$160 \mathrm{KM}$} & 0 & $\begin{array}{c}4434,17^{A} \\
(3470,46-5397,88)\end{array}$ & $\begin{array}{c}2021,56^{\mathbf{A}} \\
(1255,12-5256,76)\end{array}$ & $\begin{array}{c}2,55 \\
(1,83-3,28)\end{array}$ & $\begin{array}{c}1,97 \\
(1,89-2,24)\end{array}$ \\
\hline & 1 & $\begin{array}{c}9140,37^{\mathbf{B}^{\times}} \\
(7788,54-10492,20)\end{array}$ & $\begin{array}{c}6358,57^{\mathbf{B}^{\star}} \\
(2830,49-7699,91)\end{array}$ & $\begin{array}{c}2,50 \\
(2,10-2,90)\end{array}$ & $\begin{array}{c}2,38 \\
(1,90-2,93)\end{array}$ \\
\hline & 2 & $\begin{array}{c}976,55^{C} \\
(444,23-1508,87)\end{array}$ & $\begin{array}{c}848,91 \\
(540,66-1539,50)\end{array}$ & $\begin{array}{c}2,41 \\
(1,73-3,08)\end{array}$ & $\begin{array}{c}2,26 \\
(1,76-2,29)\end{array}$ \\
\hline & 3 & $\begin{array}{c}659,82^{\mathrm{C}} \\
(481,57-838,07)\end{array}$ & $\begin{array}{c}380,40 \\
(327,96-843,25)\end{array}$ & $\begin{array}{c}2,08 \\
(1,91-2,25)\end{array}$ & $\begin{array}{c}1,91 \\
(1,84-2,05)\end{array}$ \\
\hline & 4 & $\begin{array}{c}1320,59 \\
(936,26-1704,91)\end{array}$ & $\begin{array}{c}1074,88 \\
(976,25-1239,06)\end{array}$ & $\begin{array}{c}2,75 \\
(2,52-2,98)\end{array}$ & $\begin{array}{c}2,29 \\
(2,03-2,57)\end{array}$ \\
\hline & 5 & $\begin{array}{c}929,87 \\
(805,76-1053,99)\end{array}$ & $\begin{array}{c}1256,94 \\
(697,21-2141,62)\end{array}$ & $\begin{array}{c}2,28 \\
(2,06-2,50)\end{array}$ & $\begin{array}{c}2,84 \\
(1,87-3,18)\end{array}$ \\
\hline
\end{tabular}

Letras maiúsculas na mesma coluna indicam diferença $(p<0,05)$ entre os momentos. * na mesma linha indica diferença $(p<0,05)$ quanto à suplementação com glutamina no mesmo momento.

Elevações nas concentrações plasmáticas de cortisol relacionadas ao exercício têm sido amplamente documentadas em cavalos (MALINOWSKI et al., 1993; NESSE et al., 2000; KRAEMER et al., 2003), e o presente experimento corrobora estes estudos. É sabido que o treinamento físico altera a quantidade de cortisol produzido em cavalos que treinam e competem em diversas modalidades (MCKEEVER, 2002; CAYADO et al., 2006; FERRAZ et al., 2010; MARC et al., 2013) e esses autores concluíram que a elevação do cortisol está mais relacionada à duração do que à velocidade (intensidade) do esforço. 
Todos os cavalos de todas as categorias apresentaram aumento dos níveis de cortisol imediatamente após a prova, retornando próximo aos valores basais 3 horas após, sendo que esse aumento foi maior nos cavalos de $80 \mathrm{~km}$, seguido pelos de $120 \mathrm{~km}$ e menor nos de $160 \mathrm{~km}$.

Como se tratou de provas FEI, todos os cavalos dormiram no local da competição em baias controladas por fiscais do evento. Todos os animais apresentaram valores basais de cortisol acima dos encontrados quando esses já se encontravam em seus respectivos haras (M3, M4 e M5). Esse fato pode demonstrar que estão estranhando o ambiente ou certa ansiedade em competir, pois apesar de serem cavalos experientes, o nível de experiência entre eles é diferente e podemos observar que o aumento foi proporcional à distância da competição, ou seja, cavalos de $160 \mathrm{~km}$ (os mais experientes) apresentaram níveis basais maiores que os de $120 \mathrm{~km}$, que por sua vez, maiores que os de $80 \mathrm{~km}$. Além disso, a liberação de cortisol segue um ritmo circadiano, inclusive nos cavalos, onde a maior concentração sérica é alcançada pela manhã (IRVINE; ALEXANDER, 1994).

O aumento de cortisol em M1 foi menor nos cavalos de 80 e $160 \mathrm{~km}$ que receberam suplementação com glutamina. Como o cortisol é o hormônio responsável por formar um estoque de aminoácidos livres para utilização em exercícios prolongados e no período de recuperação, a suplementação com glutamina pode ter sido útil em fornecer aminoácido com essa finalidade e não tenha havido necessidade de liberação de tanto hormônio quanto nos cavalos que não tiveram esse aporte. Os animais de $120 \mathrm{~km}$ são intermediários na quanto à distância percorrida e o fato do cortisol em M1 não ter sido diferente nos cavalos que receberam dos que receberam, talvez indique um maior esforço desses animais, pois, os cavalos de $80 \mathrm{~km}$ apesar de também terem corrido em velocidade alta e serem menos experientes, a distância e o aporte de aminoácidos podem ter sido suficientes para haver menor ativação do eixo hipotalâmico-hipofisário. Já os cavalos de $160 \mathrm{~km}$, apesar de a distância ser maior, são mais experientes e correm em velocidade menor. As figuras 2, 3 e 4 ilustram a diferença do cortisol entre os momentos de coleta e suplementação dos animais de 80, 120 e $160 \mathrm{~km}$ que apresentaram diferença, segundo o teste de Friedman. 
Figura 2 - Diferença entre momentos de coleta do cortisol nos cavalos de $80 \mathrm{~km}$, suplementados ou não com glutamina

\section{$80 \mathrm{~km}$}
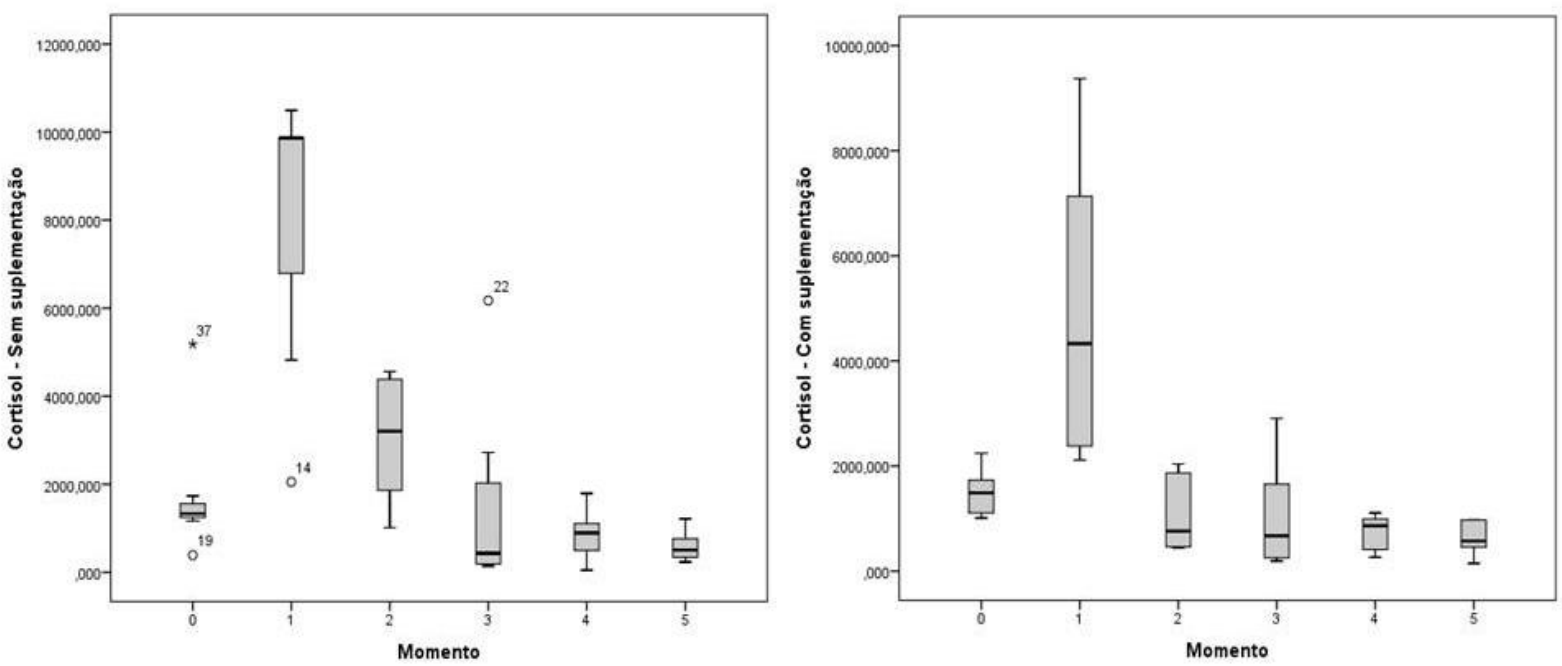

Figura 3 - Diferença entre momentos de coleta do cortisol nos cavalos de $120 \mathrm{~km}$, suplementados ou não com glutamina

\section{$120 \mathrm{~km}$}
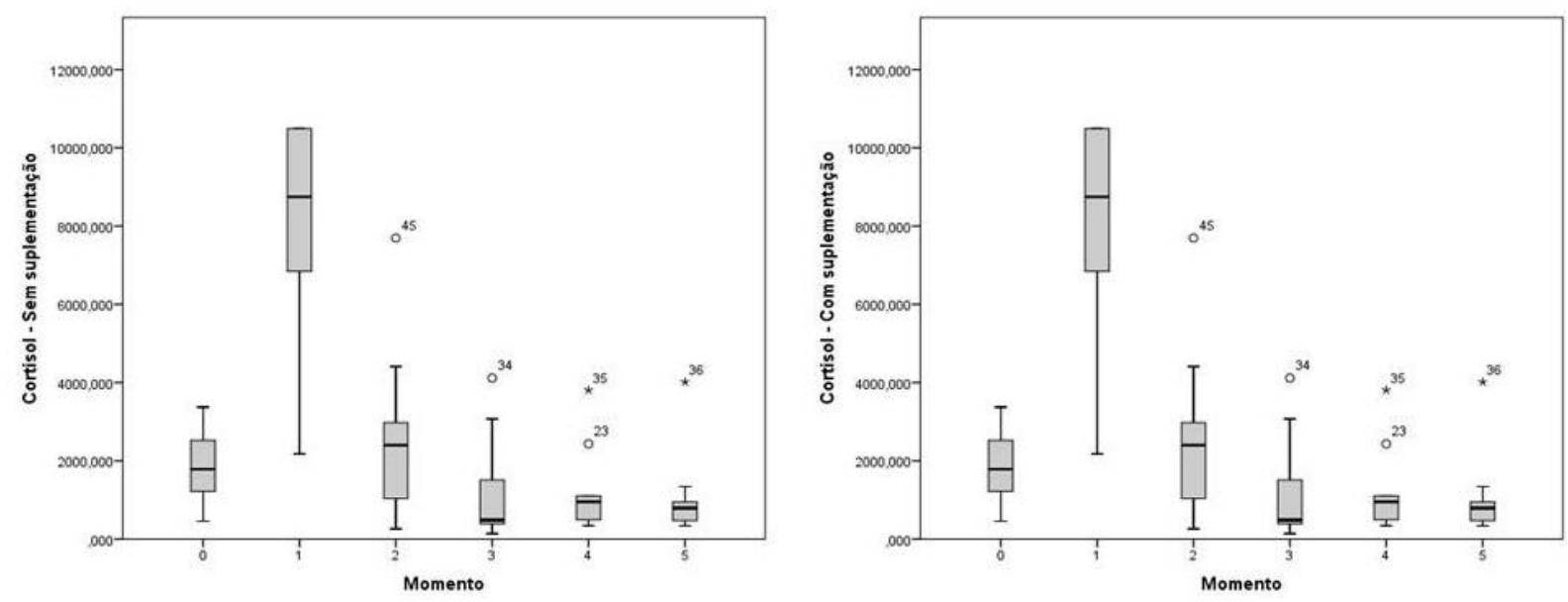
Figura 4 - Diferença do cortisol entre os momentos de coleta dos cavalos de $160 \mathrm{~km}$ suplementados com glutamina

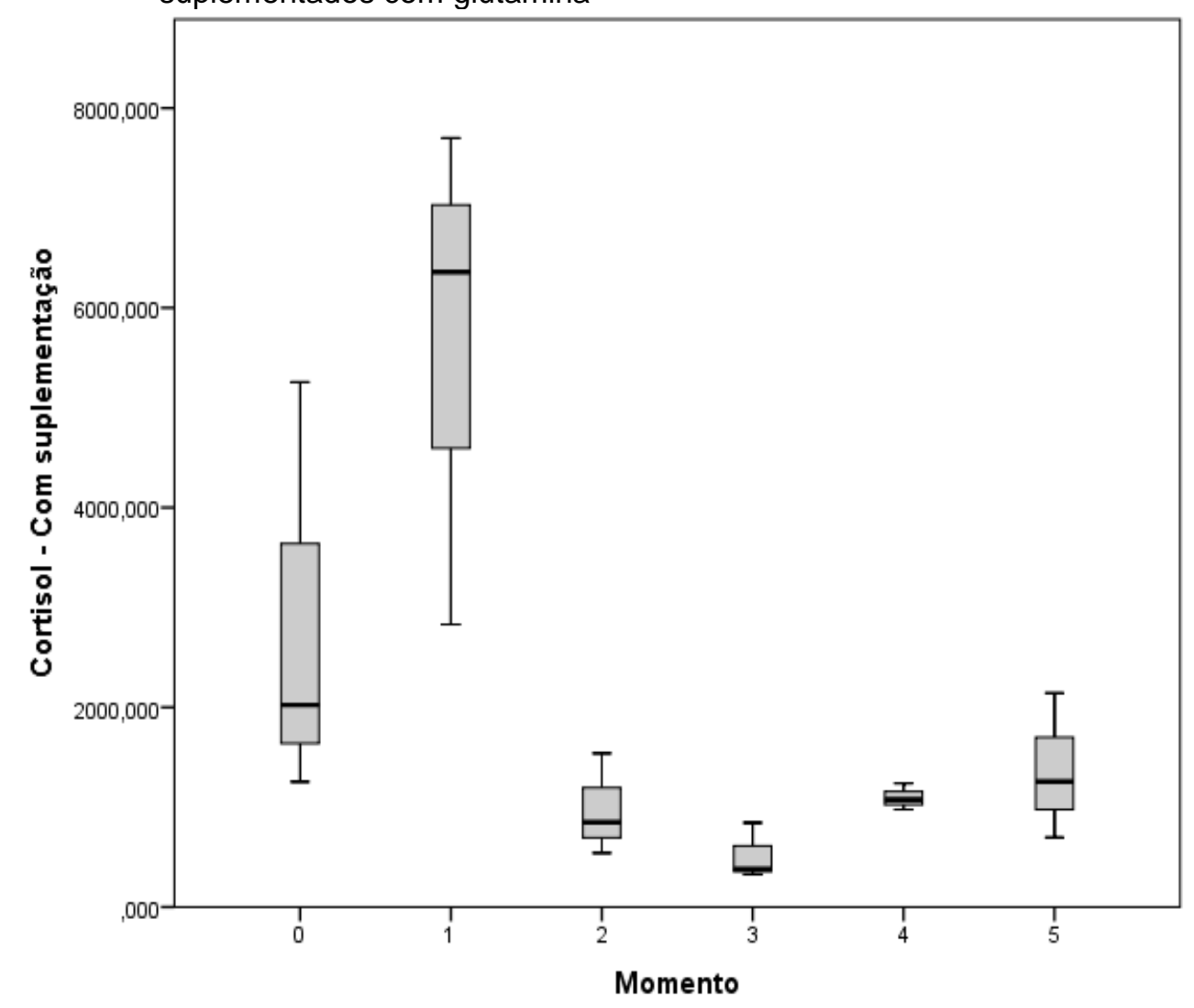

Não houve diferença nos valores de GH entre os momentos de coleta, distâncias ou quanto à suplementação com glutamina. A concentração de GH no sangue é um reflexo de três processos simultâneos, secreção basal, secreção pulsátil e liberação. Em humanos a pulsação de GH ocorre durante a noite durante a onda lenta do sono e durante o dia, níveis séricos desse hormônio são praticamente indetectáveis (GRAAF-ROELFSEMA et al., 2009). Pela sua natureza de presa, a necessidade de sono é bem menor nos cavalos que nos humanos, porém, há estudos indicando que o período de maior pulsação do GH é o da noite (CAHIL et al., 1994; CHRISTENSEN et al., 1997), o que pode dificultar a detecção de alterações durante o dia. Também há evidências que os hormônios do estresse como catecolaminas e cortisol podem inibir a secreção de $\mathrm{GH}$, diminuindo assim sua ação anabólica (GRAAF-ROELFSEMA et al., 2009).

No início dos anos 80 foi demonstrado que células do sistema imune produzem adrenocorticotropina, endorfinas, hormônio estimulador da tireoide e hormônios proteicos como prolactina e GH (WEIGENT, 1996). O GH produzido por leucócitos contém RNAm e outras moléculas idênticas em termos de peso molecular e 
antigenicidade ao GH produzido na pituitária. Outros estudos (KELLEY, 2004; ZHU et al., 2005), tratando leucócitos com GH, conseguiram modular a resposta humoral e celular através da produção de imunoglobulinas pelas células $B$, secreção de timulina pelas células epiteliais do timo, aumento da resposta de células NK, fagocitose e burst oxidativo em macrófagos e neutrófilos. Além disso, o GH derivado de linfócitos regula a sensibilidade e produção de IGF-I e é ativo na proteção contra apoptose. $\mathrm{O}$ GH linfocitário também estimula a síntese de IFNy e pode ser inibido pelo cortisol e norepinefrina (KELLEY et al., 2007).

Muitas evidências sugerem que o exercício extenuante de alta intensidade ou de longa duração pode promover imunossupressão que pode conduzir a um aumento da susceptibilidade à doença em atletas humanos e equinos. Acredita-se que essa condição resulta de alterações tanto em número quanto em funções dos leucócitos circulantes e vários estudam confirmam isso (HINES et al.,1996; NIEMAN, 1997; ROBSON et al., 2003). No entanto, os resultados são muito variáveis, sugerindo que a resposta é heterogênea (CYWINSKA et al., 2012).

A tabela 4 mostra os valores das medianas, primeiro e terceiro quartis de eosinófilos, neutrófilos e linfócitos dos cavalos de 80, 120 e $160 \mathrm{~km}$, suplementados ou não com glutamina. 
Tabela 4 - Valores da mediana, primeiro e terceiro quartis de eosinófilos, neutrófilos e linfócitos nos cavalos que competiram em 80,120 e 160 km, suplementados ou não com glutamina

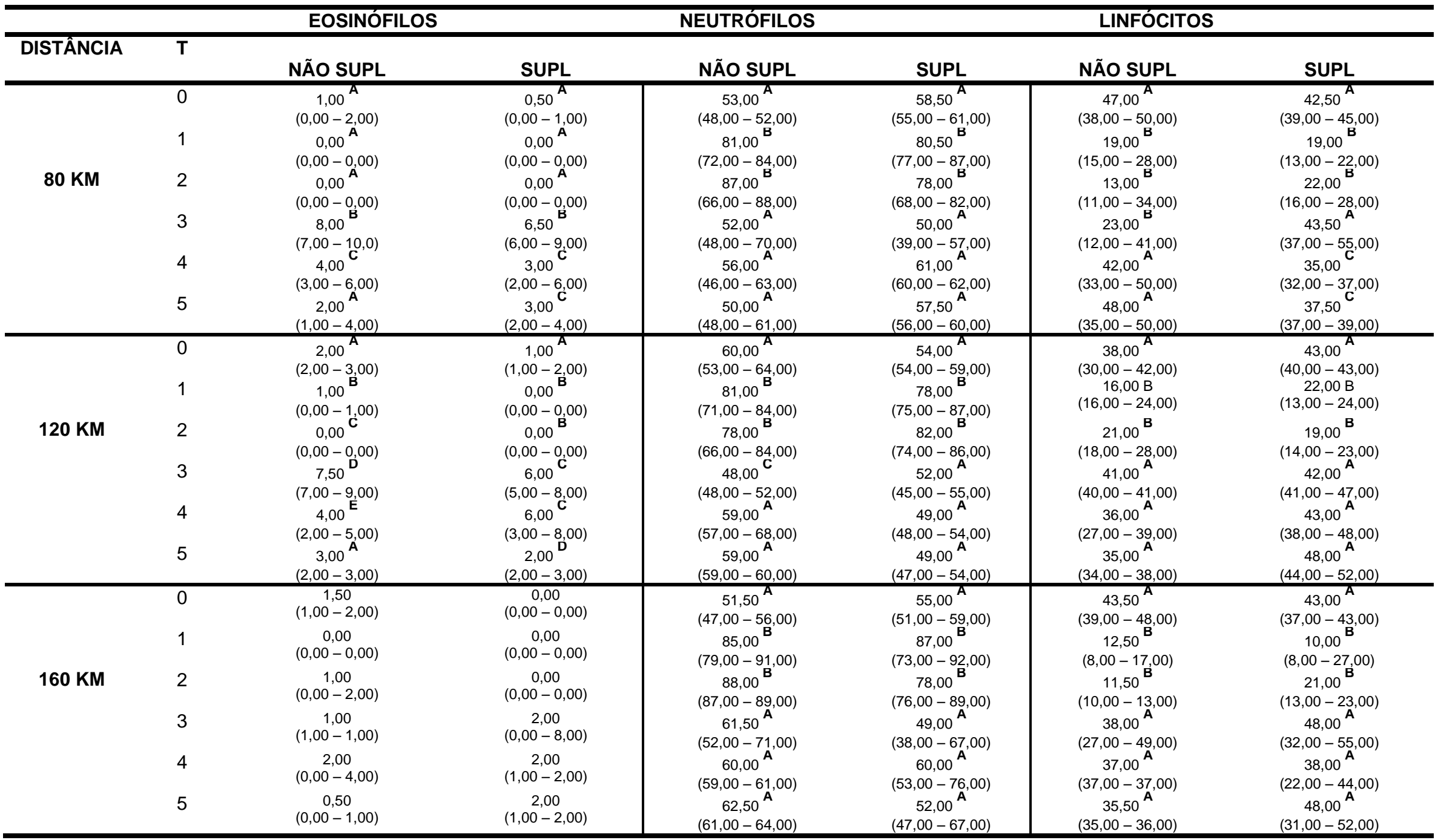

Letras maiúsculas na mesma coluna indicam diferença $(p<0,05)$ entre os momentos. ${ }^{*}$ na mesma linha indica diferença $(p<0,05)$ quanto à suplementação com glutamina no mesmo momento. 
Houve pronunciado aumento do número de eosinófilos três dias após a prova nos cavalos de 80 e $120 \mathrm{~km}$. Esse aumento ocorreu tanto nos animais que não receberam suplementação, quanto nos que receberam, embora nestes, o aumento tenha sido menor, como mostram as figuras 5 e 6 .

Figura 5 - Diferenças entre momentos no número de eosinófilos nos cavalos de $80 \mathrm{~km}$, quanto à suplementação de glutamina

\section{$80 \mathrm{KM}$}
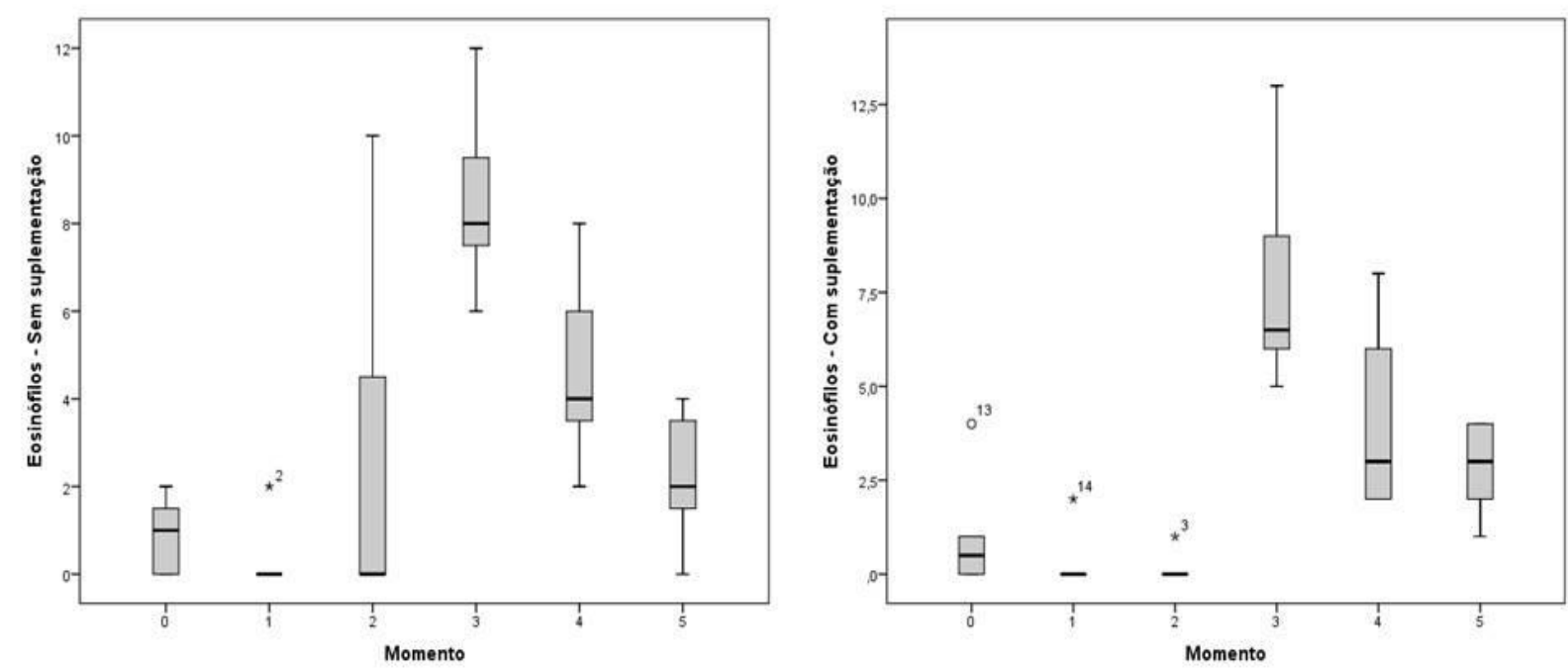

Figura 6 - Diferenças entre momentos no número de eosinófilos nos cavalos de $120 \mathrm{~km}$, quanto à suplementação de glutamina

\section{$120 \mathrm{KM}$}
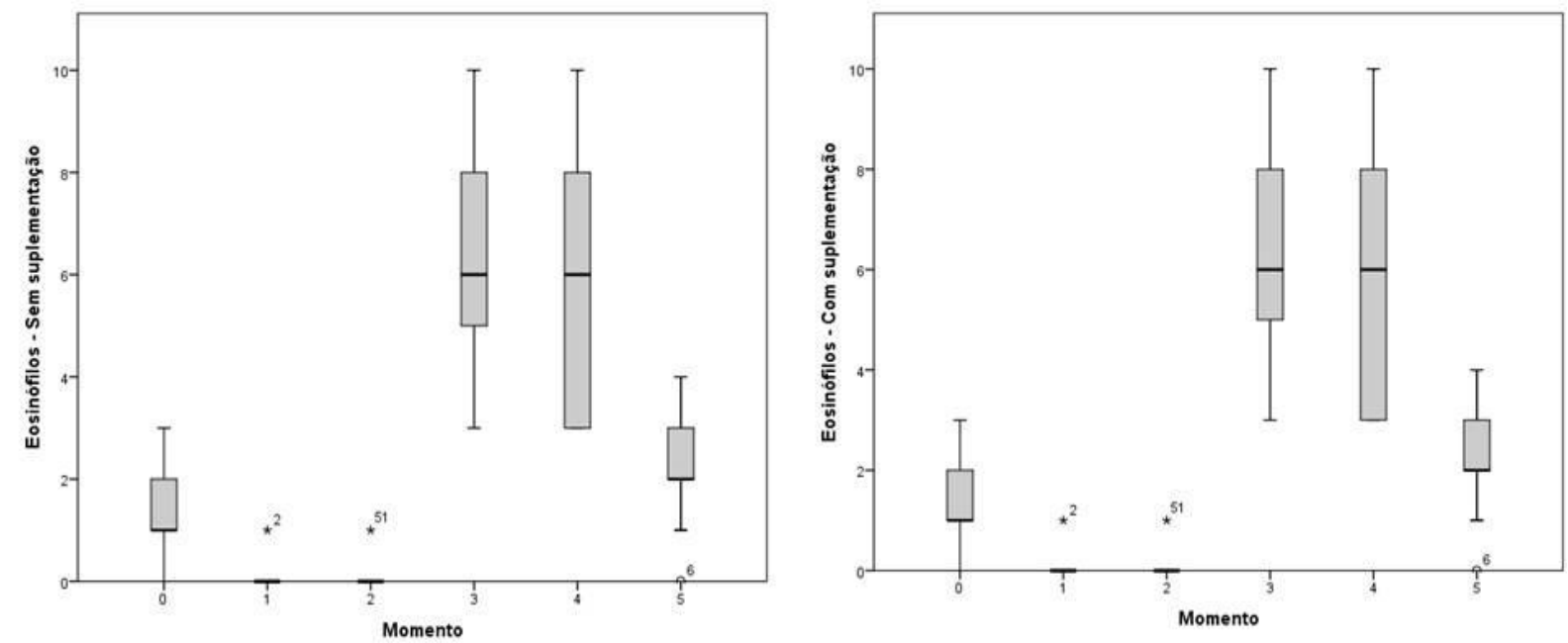
Eosinófilos são granulócitos produzidos na medula óssea e acredita-se que para cada célula presente na circulação haja de 100-300 células nos tecidos, preferencialmente pulmões, pele e intestinos. Na medula, a produção de eosinófilos é regulada por diversos fatores de crescimento como IL-3, IL-5 e fator estimulador de colônia granulocítica-macrofágica (GM-CSF). Os eosinófilos produzem diferentes tipos de proteínas em seus grânulos responsáveis pela sua ação nos patógenos e produzem também algumas citocinas, como IL-2, IL-6, IL-8, TGFa e TGF $\beta$. A maioria dessas citocinas age como fatores de crescimento para outros eosinófilos e ativação de células maduras, o que potencialmente interfere nos processos inflamatórios (VENGE, 1998).

Os eosinófilos são reconhecidos como células pró-inflamatórios do trato respiratório, com considerável potencial de causar danos. O exercício aeróbico de resistência afeta tanto compartimentos sistêmicos quanto as vias respiratórias, aumentando a incidência de doenças infecciosas e alérgicas que provocam broncoconstrição e hiper-responsividade do epitélio respiratório (MCKUNE et al., 2004). Um efeito similar tem sido encontrado nos equinos atletas, principalmente os de corrida que são predispostos a desenvolver pleuropneumonia, porém, os macrófagos pulmonares dos cavalos parecem possuir interação mais complexa com o meio ambiente e com outras células do sistema imune que os dos humanos (RAIDAL et al., 2001). Tanto o exercício de resistência quanto o de força em humanos podem ativar eosinófilos por via não alérgica, pois essas células também participam do processo de regeneração da musculatura lesionada através da modificação da produção de glicosaminoglicanos pelos fibroblastos. Outra possível explicação é que a resposta de fase aguda na musculatura lesionada ativa o sistema complemento ( $\mathrm{C} 3, \mathrm{C} 4$ e C5) e esses fragmentos podem ativar os eosinófilos (DUFAUX et al., 1993). McKune et al. (2004) estudaram concentrações séricas de proteína eosinofílica catiônica (ECP) em ultramaratonistas humanos perceberam que tanto a ECP quanto o número de eosinófilos permaneceram alterados após 72 horas da prova, exatamente como ocorreu no presente estudo. Os cavalos de $160 \mathrm{~km}$ não sofreram essa alteração, talvez pela experiência e maior tempo de treinamento que os demais, possuam a musculatura mais adaptada.

O esforço físico é associado a alterações na contagem de células brancas, dependentemente da duração e intensidade. Modificações nos hormônios do estresse, concentração de citocinas, temperatura corporal, aumento do fluxo 
sanguíneo, vasoconstrição e desidratação são mecanismos envolvidos na alteração da contagem de leucócitos, principalmente após exercício prolongado em alta intensidade. A adrenalina aumentada durante o exercício recruta linfócitos, principalmente do baço onde existe o maior estoque dessas células para o sangue, porém, sua ação é atenuada pelo aumento do cortisol no fim do exercício (NIEMAN, 1997). O cortisol aumenta a liberação de neutrófilos da medula óssea na circulação e o aumento do débito cardíaco provoca turbilhonamento do sangue aumentando a mobilização de leucócitos de pools marginais como parede das veias (ROBSON et al., 2003). Esses fatores provocam uma alteração bifásica da contagem de células brancas na circulação, sendo que durante o exercício predomina linfocitose e no final, os neutrofilia (RISØY et al., 2003).

Todos os cavalos sofreram aumento na contagem de neutrófilos e diminuição da contagem de linfócitos no pós prova e três horas depois, retornando ao normal a partir do terceiro dia. Robson et al. (2003); Cywińska et al. (2010) e Cywińska et al. (2012) estudaram cavalos de enduro de regularidade, velocidade livre curta e longa distância e todos encontraram a mesma alteração. A linfocitose pode vir acompanhada da ativação desses linfócitos (NIELSEN, 2003), o que foi visto em todos os cavalos desse estudo desde o pós prova até três dias. Robson et al. (2003) encontraram neutrofilia e linfopenia evidentes 1 hora e 1 dia após enduro de $80 \mathrm{~km}$ e retornou a normalidade somente 3 dias após, exatamente como ocorreu no presente estudo. Estudaram também a atividade dos leucócitos, onde encontraram diminuição do burst oxidativo tanto em neutrófilos quanto em monócitos 1 hora e 1 dia após a prova, retornando ao normal somente 8 dias após. Porém, quando se trata de linfócitos, a resposta parece ser bem heterogênea. Alguns autores (KURCZ et al., 1998; LUNN et al., 2001) que trabalharam com cavalos em esteira rolante de alta velocidade encontraram supressão da resposta proliferativa de linfócitos, porém Cywińska et al. (2012), encontraram diminuição dessa resposta somente em cavalos de longa distância $(160 \mathrm{~km})$ e não nos cavalos de regularidade.

Houve diferença quanto à suplementação de glutamina no número de linfócitos nos cavalos de $80 \mathrm{~km}$ e $120 \mathrm{~km}$ nos diferentes momentos de coleta, como ilustram as figuras 7 e 8 , segundo o teste de Friedman. 
Figura 7 - Diferença no número de linfócitos nos momentos de coleta dos cavalos de 80 suplementados com glutamina

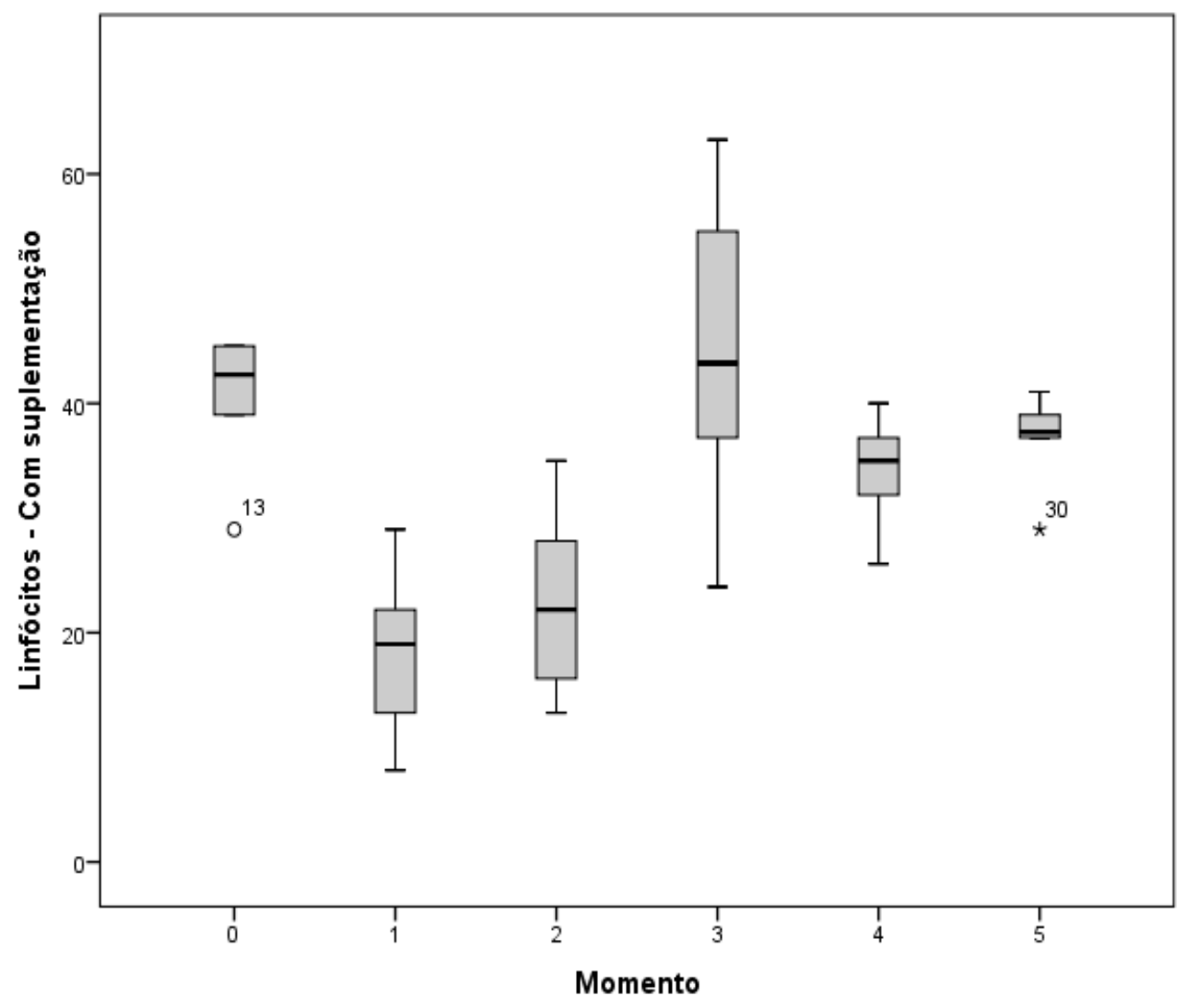


Figura 8 - Diferença no número de linfócitos nos momentos de coleta dos cavalos de 120 suplementados com glutamina

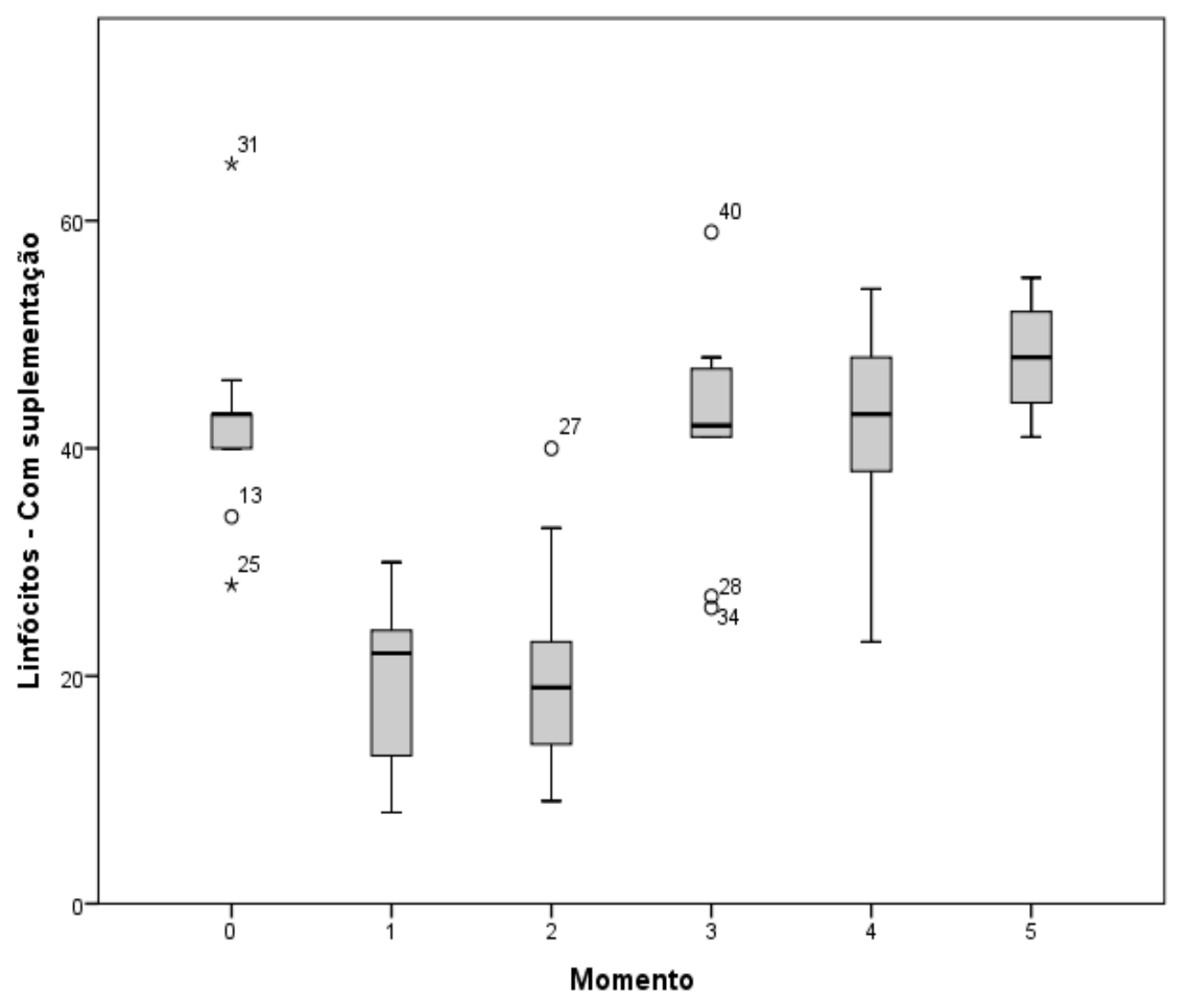

Como esse experimento foi realizado a campo, em cidades diferentes, com cavalos competindo em categorias diferentes, sendo que o horário de chegada de cada um era imprevisível, tornou-se impossível retornar ao laboratório no mesmo dia, então, optou-se por trabalhar com leucócitos congelados. Para tanto, foi realizado um estudo piloto prévio, onde se avaliou a viabilidade das células após diferentes tempos de estocagem em geladeira antes do congelamento e os efeitos da criopreservação após 3 meses de congelamento a $-80^{\circ} \mathrm{C}$. Apesar de ter havido diminuição do número de células após o descongelamento de todas as amostras, não houve diferença do número de células vivas entre o sangue fresco e o sangue armazenado 24 horas $(p=0,1)$. Embora a criopreservação de células do sangue possa causar modificações em subpopulações de células brancas, devido à sua heterogeneidade, como resultado do processo de congelamento/descongelamento, estudos comprovaram que pode ser um método útil para imunofenotipagem, já que não ocorrem modificações em números $\mathrm{CD}^{+} \mathrm{CD}^{+}{ }^{+}$e $\mathrm{CD} 3^{+} \mathrm{CD} 8^{+}$, congelados até 48 
horas após a coleta (SCHUMACHER; BURKHEAD, 2000; SPUTTEK et al., 2007; WEINBERG et al., 2009).

A tabela 5 a seguir mostra os valores das medianas, primeiro e terceiro quartis da relação neutrófilos/linfócitos e $\mathrm{LT} \mathrm{CD}^{+} / \mathrm{CD}^{+}$dos cavalos de 80, 120 e $160 \mathrm{~km}$, suplementados ou não com glutamina.

Tabela 5 - Valores da mediana, primeiro e terceiro quartis das relações entre neutrófilos e linfócitos e linfócitos T CD4 e CD8 nos cavalos que competiram em 80, 120 e 160 km, suplementados ou não com glutamina

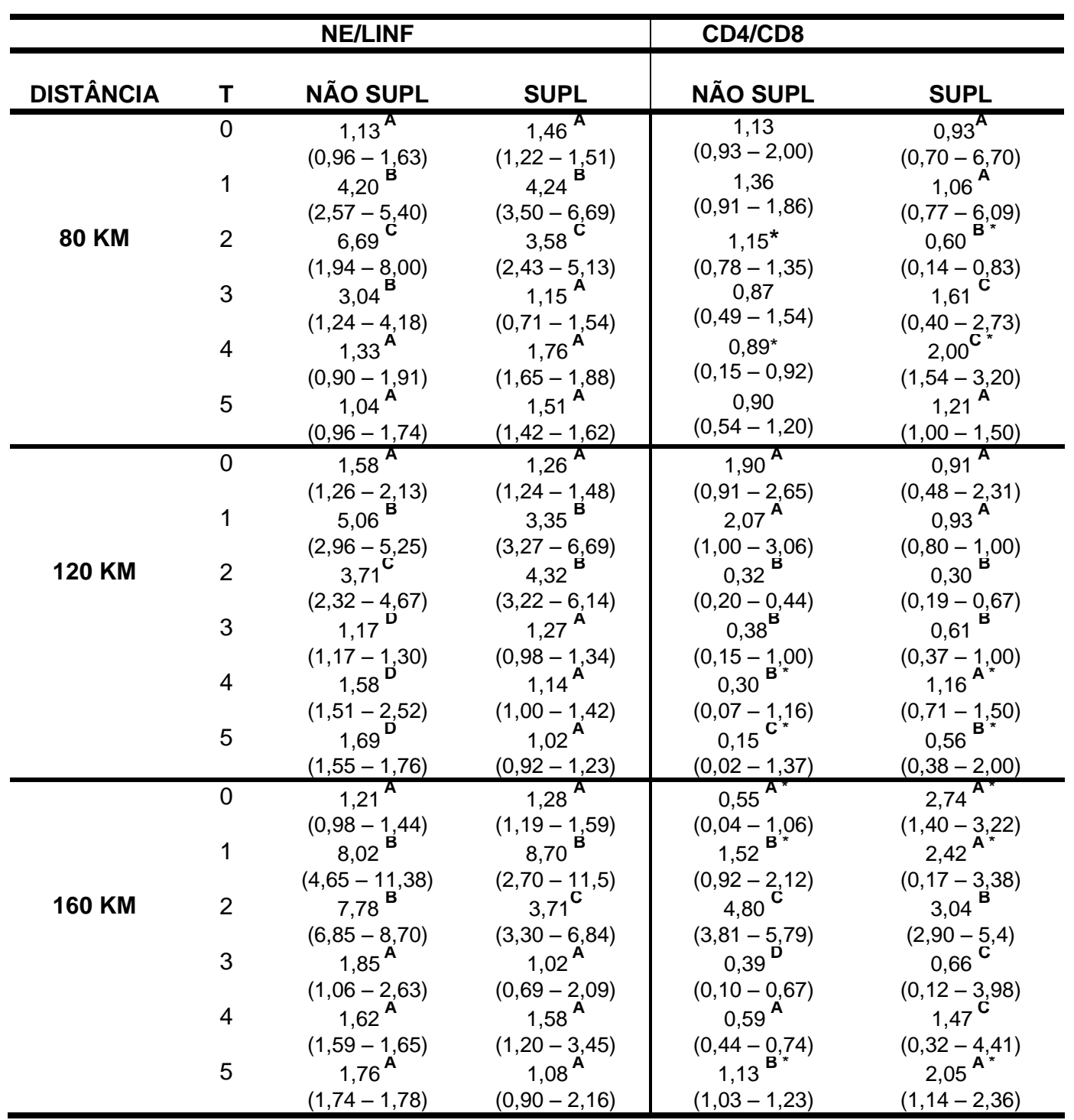

Letras maiúsculas na mesma coluna indicam diferença $(p<0,05)$ entre os momentos. * na mesma linha indica diferença $(p<0,05)$ quanto à suplementação com glutamina no mesmo momento. 
Houve aumento na relação neutrófilos/linfócitos imediatamente após a prova e três horas depois em todos os cavalos, de todas as categorias independentemente da suplementação, porém, esse aumento foi atenuado em indivíduos suplementados nas três distâncias. Essa neutrofilia é esperada e muito bem relatada por outros autores (ROBSON et al., 2003; KRUMRYCH, 2006; CYWINSKA et al., 2010; CYWYNSKA et al., 2012).

Não houve alteração na relação $\operatorname{CD4/CD8~nos~cavalos~de~} 80 \mathrm{~km}$ que não receberam suplementação e nos que receberam, houve diminuição três horas após a prova e aumento três e sete dias depois. Os cavalos de $120 \mathrm{~km}$ que não receberam suplementação apresentaram diminuição desde três horas até sete dias após a prova, já os que receberam apresentaram diminuição somente três horas a três dias após, retornando mais rapidamente ao normal. Os cavalos de $160 \mathrm{~km}$ com e sem suplementação apresentaram aumento três horas e diminuição em três dias após a prova, sendo que nos cavalos suplementados, a diminuição permaneceu até sete dias. Não houve alteração logo após a prova em nenhum cavalo, independentemente da distância e suplementação. As modificações foram mais tardias que as relatadas por todos os outros autores.

Quase todos os estudos com humanos são unânimes em afirmar que o exercício prolongado causa uma redistribuição nos linfócitos $\mathrm{T}$, diminuindo a relação CD4/CD8, ou seja, aumenta o número de LT CD8 e passa haver predominância de $\mathrm{T}_{\mathrm{h} 2}$ imediatamente após, o que está associado à imunossupressão no período de recuperação (PEDERSEN; HOFFMAN-GOETZ, 2000; StEENSBERG et al., 2001; GLEESON; BISHOP, 2005; LANCASTER et al., 2005). Segundo Nielsen (2003), as frações CD 16+ NK também aumentam juntamente com o LT CD8 ${ }^{+}$. Apesar da diversidade de fatores que são ativados quando a integridade do corpo é desafiada, um conjunto estereotipado de vias neuroendócrinas é fortemente envolvido. A presença de receptores para os hormônios do sistema endócrino e o contato anatômico entre os sistemas linfoide e nervoso podem revelar a existência de vias de comunicação entre eles. A epinefrina e a norepinefrina aumentam de maneira quase linear durante o exercício e exponencialmente em relação à intensidade, expressa individualmente pelo $\mathrm{VO}_{2 \text { máx. }} \mathrm{A}$ expressão de $\beta$-adrenoreceptores em células $T, B, N K$, macrófagos e neutrófilos permite que essas células sejam alvos das catecolaminas. Como os $\beta$-receptores em linfócitos estão ligados intracelularmente ao sistema de geração de segundo mensageiro, a quantidade 
desses receptores pode mudar conforme há ativação e diferenciação dessas células. O número dos receptores adrenérgicos nas subpopulações de linfócitos pode determinar o grau que as células são mobilizadas em resposta a catecolaminas e as subpopulações possuem números diferentes de receptores, ou seja, existe uma correlação entre a quantidade de receptores adrenérgicos e a responsividade ao exercício. As células NK contêm o número mais elevado de receptores adrenérgicos, enquanto que os linfócitos $\mathrm{T} \mathrm{CD} 8^{+}$são intermediários e os linfócitos $\mathrm{T} \mathrm{CD4}^{+}$são os que possuem menor número. Talvez isso faça com que as NK sejam mais responsivas ao exercício e a outros estressores e os LT CD4 ${ }^{+}$, menos responsivos (PEDERSEN; HOFFMAN-GOETZ, 2000).

São poucos estudos que avaliam o efeito do exercício sobre essa possível inversão entre $T_{h 1}$ e $T_{h 2}$ em equinos atletas. Um experimento realizado por Hines et al. (1994) com 3 cavalos que completaram uma prova de 50 milhas ( $80 \mathrm{~km})$, mostrou que também houve diminuição da relação CD4/CD8 após a prova. Já Foz et al. (2009), estudaram cavalos de polo de elite exercitados em esteira rolante de alta velocidade e perceberam um aumento do número tanto de LT CD4 quanto de LT CD8 após sprint e diminuição de ambas as células no desaquecimento e após, não alterando a relação entre elas. Todos os cavalos do presente estudo começaram a apresentar alterações, tanto de aumento, quanto de diminuição da relação CD4/CD8 somente a partir de três horas após a prova.

O cortisol é um hormônio com funções antagônicas à adrenalina quanto à mobilização de linfócitos e os níveis de todos os cavalos apresentaram-se elevados logo após o término da prova, diminuindo três horas após. Talvez, no momento em que a concentração de cortisol comece a normalizar, permita que ocorra a dinâmica dos linfócitos. Pelo fato do enduro equestre ser realizado em muitas horas de competição, a atuação da adrenalina deve ser em momentos pontuais como na largada, quando o cavaleiro peça galope mais aberto, em determinados trechos durante o percurso, e em relargadas ou em sprints finais (muito frequentes hoje em dia, inclusive em alguns cavalos desse estudo). Já o cortisol aumenta conforme aumenta o tempo e intensidade de exercício, sendo talvez, mais atuante nesses cavalos.

As figuras 9 e 10 mostram a diferença na relação entre LT CD4/CD8 nas diferentes distâncias, sem suplementação e com, respectivamente, em M2, pois esse foi o momento onde as diferenças começaram a aparecer. 
Figura 9 - Diferença na relação entre LT CD4/CD8 em M2 nas diferentes distâncias, sem suplementação, segundo o teste de Kruskal-Wallis

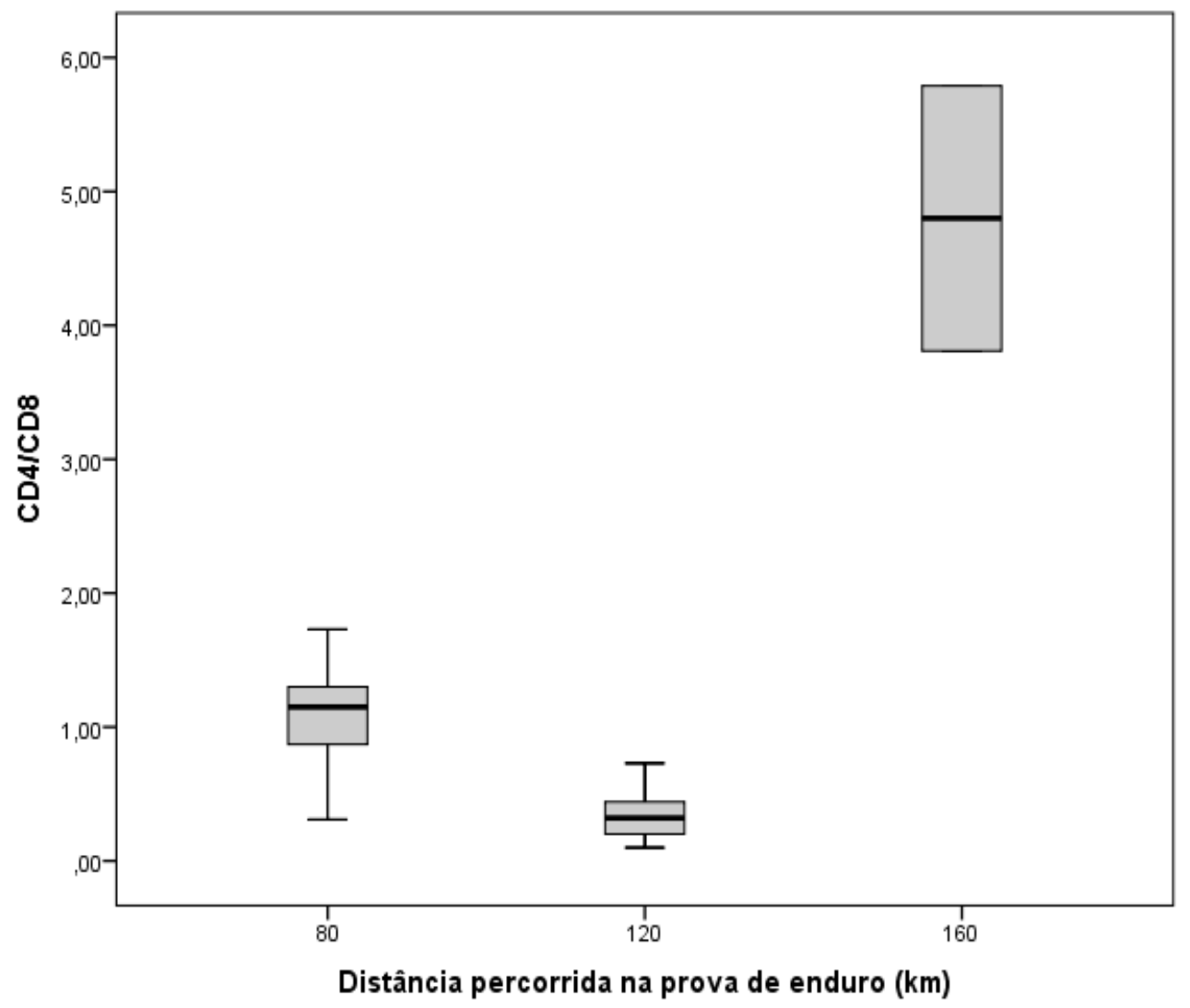


Figura 10 - Diferença na relação entre LT CD4/CD8 em M2 nas diferentes distâncias, com suplementação, segundo o teste de Kruskal-Wallis

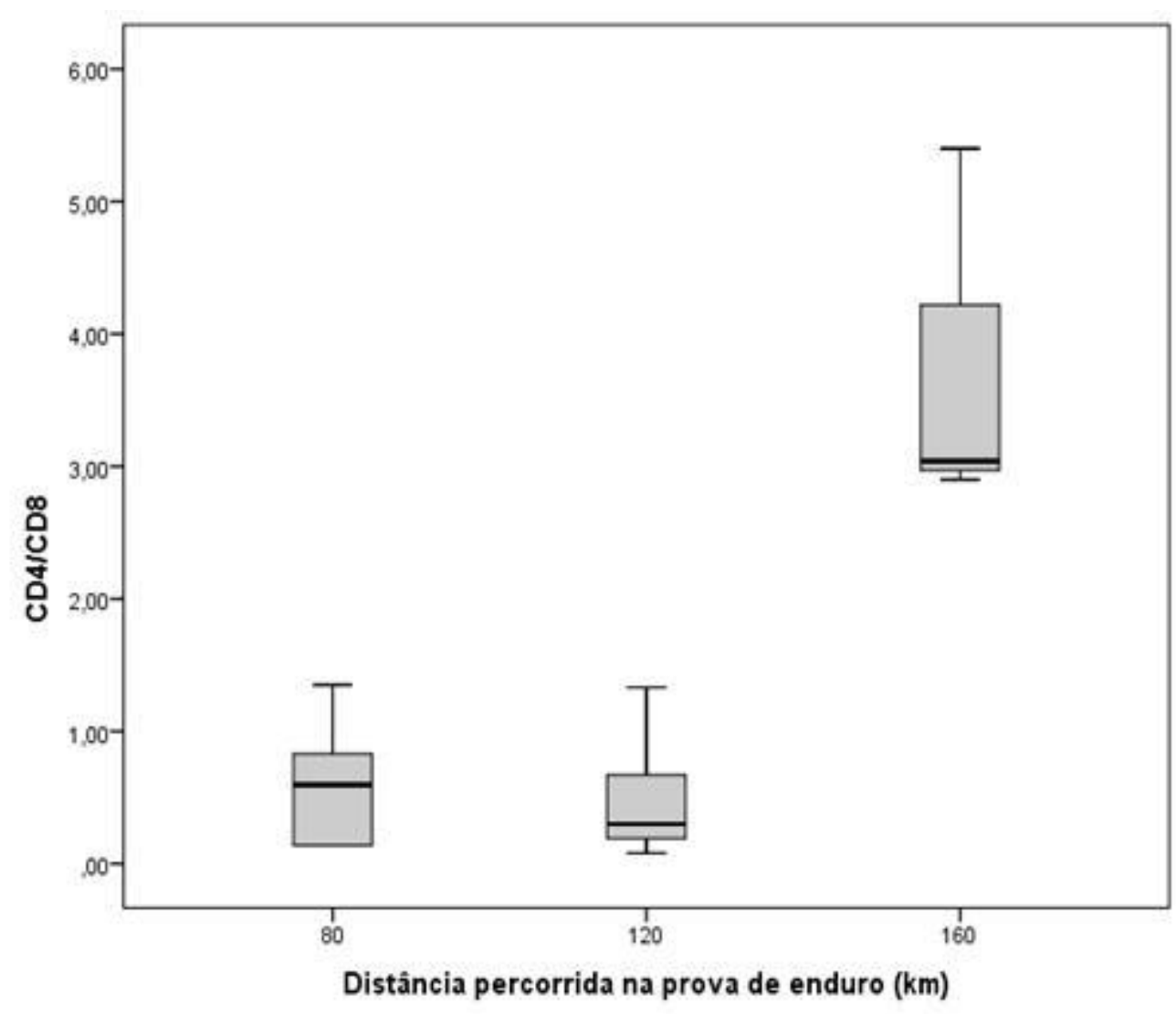

O exercício modula tanto o metabolismo de glicose quanto o de glutamina, o que influencia na função de linfócitos. A glutamina aumenta os níveis de GSH intracelular especialmente importante nos processos de ativação e proliferação linfocitária, através da sua conversão em glutamato, precursor de glutationa. Estresse oxidativo causa redução da resposta linfocitária a mitógenos ou antígenos e a GSH é o antioxidante mais abundante nas células de mamíferos. Concentração inadequada de glutamina pode comprometer a expressão de CD25 e CD45RO e diminuir a razão entre CD4/CD8, diminuir a produção de IL-2 e IFNy (CHANG et al., 1999). Outras funções dos linfócitos dependentes de IL-2, como proliferação de células $T$, geração de blastos de LT CD8+, atividade citotóxica, ativação de células por linfocinas e células NK, também são particularmente sensíveis à depleção de GSH (DRÖGE; BREITKREUTZ, 2000).

Os cavalos desse estudo que receberam suplementação com glutamina apresentaram diminuição da relação CD4/CD8 três horas após a prova e alguns até 
três dias depois, porém, retornaram ao normal ou aumentaram essa relação mais rapidamente que os que não receberam, nos quais a diminuição permaneceu até sete dias após a prova. Estudos que avaliam a suplementação com glutamina sobre o sistema imune de humanos são controversos, Castell et al. (1997) avaliaram 18 corredores de maratona e não encontraram nenhum efeito sobre LT CD4, CD8, IL-1, IL-2 e IL-6. Rohde et al. (1998) avaliaram 16 corredores de maratona e também não encontraram nenhum efeito da glutamina sobre LT CD4, CD8, CD16, neutrófilos, resposta proliferativa a PHA e atividade de células NK. Porém, estudos in vitro, mostraram que a glutamina aumenta a proliferação de linfócitos (ARDAWl; NEWSHOLME, 1983; GRIFFITHS; KEAST, 1990; PARRY-BILLINGS et al., 1990; YAQOOB; CALDER, 1997).

Wells et al. (1999) avaliaram a suplementação crônica de glutamina via oral (6 semanas) em camundongos e perceberam que houve aumento das citocinas de $T_{h 1}$, especialmente de IL-2 e IFNy, assim como houve aumento na proporção de LT CD4/CD8. A suplementação crônica (45 dias) dos cavalos do presente estudo parece ter atenuado a diminuição da relação CD4/CD8, porém, só é possível afirmar isso em relação aos não suplementados e não em comparação a outros estudos com equinos, pois os que avaliam o efeito do exercício sobre o sistema imune têm como foco a proliferação celular in vitro (CYWINSKA et al., 2012) ou utilizam lavado broncoalveolar e não sangue (RAIDAL et al., 2000; RAIDAL et al., 2001; DEATON et al., 2002).

Brown et al. (2013) estudaram o efeito do exercício na redistribuição de populações de linfócitos em atletas humanos e perceberam que tanto os linfócitos $T$ CD4 quanto os CD8 efetores e de memória com perfil senescente eram preferencialmente mobilizados da circulação. Linfócitos senescentes são aqueles que já não reconhecem antígenos novos, porém ainda permanecem com funções efetoras imediatas como morte de células viralmente infectadas. Essa mobilização de linfócitos senescentes em resposta ao exercício fornece espaço para linfócitos virgens, pois ao final do exercício, quando egressam aos tecidos periféricos sofrem apoptose. Perceberam também que indivíduos treinados possuíam menos linfócitos 
senescentes (CD4 e CD8) que os não treinados, assim como a redistribuição de linfócitos T CD8+ virgens também era maior em atletas. (no prelo) ${ }^{1}$

O exercício físico extenuante induz lesões musculares que produzem uma resposta inflamatória inespecífica. Depois do processo inflamatório ser ativado, as células proveem ampla variedade de mediadores inflamatórios e fatores de crescimento. Leucocitose, com aumento de neutrófilos e monócitos e diminuição de linfócitos, é um fenômeno bem descrito em maratonistas humanos e coincide com o aumento de marcadores inflamatórios como CK, CRP e IL-6 (SHIN; LEE, 2013).

A tabela 6 mostra os valores das medianas, primeiro e terceiro quartis das interleucinas IFNy, IL-2, 1L-4 e IL-10 dos cavalos que competiram em 80, 120 e 160 km, suplementados ou não com glutamina.

\footnotetext{
${ }^{1}$ BROWN, F. F.; BIGLEY, A. B.; SHERRY, C.; NEAL, C. M.; WITARD, O. C.; SIMPSON, R. J.; GALLOWAY, S. D. R. Training status and sex influence on senescent $T$ lymphocyte redistribution in response to acute maximal exercise. Brain Behavior and Immunology, 2013. (no prelo)
} 
Tabela 6 - Valores da mediana, primeiro e terceiro quartis de IFNy, IL-2, IL-4 e IL-10 nos cavalos que competiram em 80 , 120 e $160 \mathrm{~km}$, com ou sem suplementação de glutamina

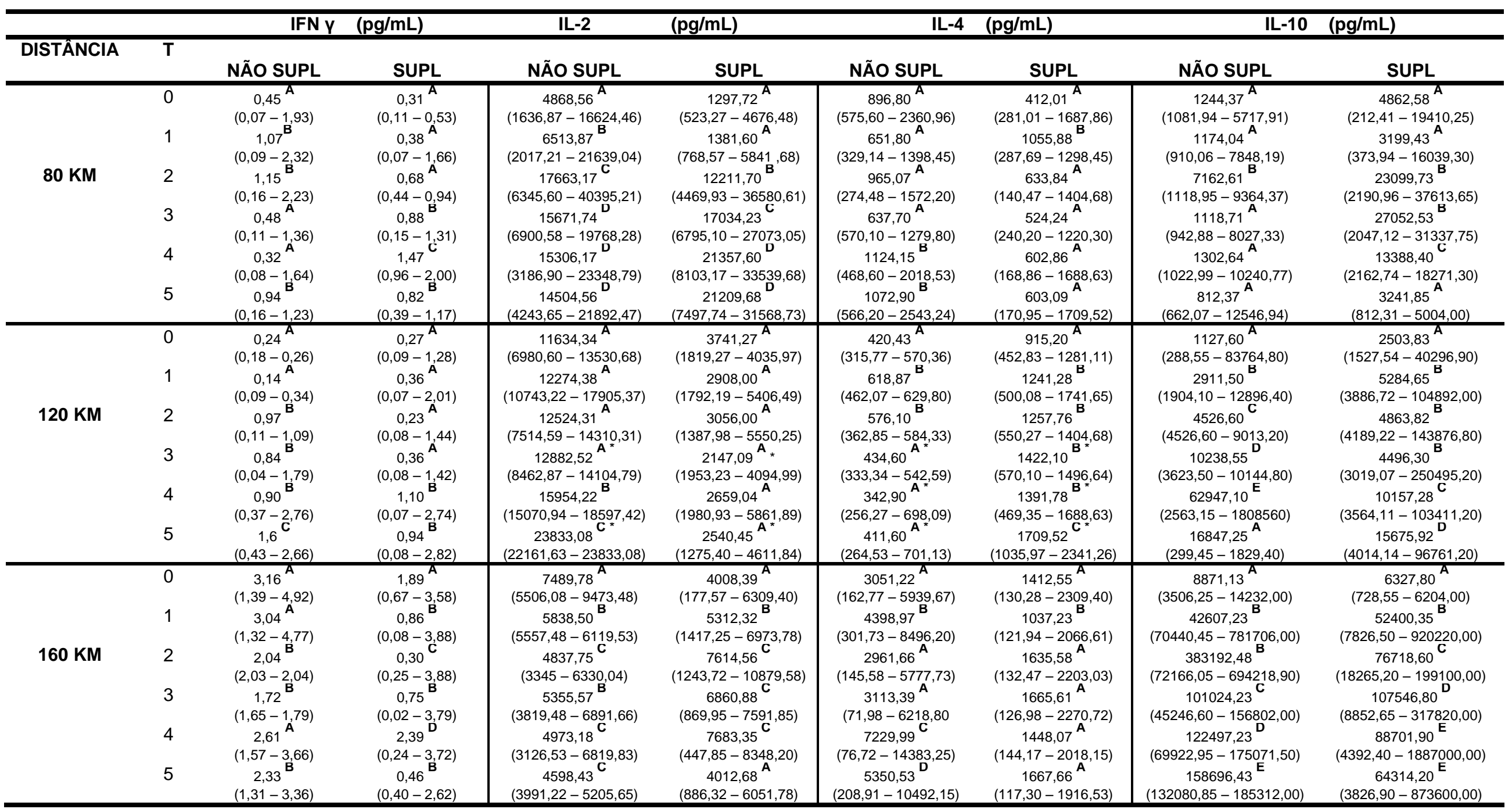

Letras maiúsculas na mesma coluna indicam diferença $(p<0,05)$ entre os momentos. ${ }^{*}$ na mesma linha indica diferença $(p<0,05)$ quanto à suplementação com glutamina no mesmo momento. 
O exercício de resistência extenuante induz o recrutamento de linfócitos para a circulação, embora a contagem de linfócitos seja menor que os valores basais (IBFELT et al., 2002). Poucos linfócitos T helper $\left(C D 4^{+}\right)$e um número maior de linfócitos $\mathrm{T}$ citotóxicos $\left(\mathrm{CD}^{+}\right)$são encontrados na circulação. As células T CD8 ${ }^{+}$são mais mobilizadas que as $\mathrm{CD}^{+}$e alguns autores (BRUUNSGAARD et al., 1999; CEDDIA et al., 1999) sugerem que as células mais recrutadas para o sangue são as células $\mathrm{T}$ de memória $\left(\mathrm{CD} 45 \mathrm{RO}^{+}\right)$em relação às células $\mathrm{T}$ virgens $\left(\mathrm{CD} \mathrm{R} \mathrm{A}^{+} \mathrm{e}\right.$ $\mathrm{CD62L}^{+}$). A existência de uma resposta funcional tanto para as células CD4 quanto para as CD8 dependem de citocinas que produzem; as $T_{h 1}$ produzem IFN e IL-2 e as $\mathrm{T}_{\mathrm{h} 2}$, IL-4 (STEENSBERG et al., 2001).

INFy é uma citocina pró-inflamatória sintetizada por linfócitos $\mathrm{T}$ helper e células NK. Age estimulando macrófagos, linfócitos T citotóxicos, células NK, linfócitos B e participa da síntese do óxido nítrico. Muitos estudos com outras espécies, principalmente humanos, relatam que exercício muito intenso ou longo provoca inibição na produção de IFNy, e por isso sugerem que ocorra imunodepressão no período de recuperação (HAAHR et al., 1991; WEINSTOCK et al., 1997; NORTHOFF et al., 1998; SUZUKI et al., 2002). Outros autores, ainda trabalhando com humanos, relataram aumento nos níveis plasmáticos de IFNy no pós-exercício e sugerem que a resposta desta citocina seja relativa ao esforço (BAUNN et al., 1997; KIMURA et al., 2001).

No presente estudo, nos cavalos de 80 e 120 km que não receberam glutamina, houve aumento de IFNy (80 km no final da prova, três horas após e quatorze dias depois e $120 \mathrm{~km}$ três horas, três dias e sete dias depois). Mas, os de 160 apresentaram diminuição em três horas e três dias após. Os cavalos de 80 e $120 \mathrm{~km}$ suplementados apresentaram um aumento mais tardio $(80 \mathrm{~km}$, três, sete e quatorze dias e 120 km, sete e quatorze dias após a prova). Nos de 160 km houve diminuição logo após o final da prova, três horas, três dias e quatorze dias depois.

Liburt et al. (2010) avaliaram a expressão de citocinas inflamatórias em éguas de sela submetidas a exercícios incrementais em esteira rolante e também notaram aumento da expressão de RNAm para IFNy seguido do aumento plasmático e o aumento dos níveis plasmáticos, por sua vez, foi seguido do aumento dos níveis musculares. Por esse fato, os autores sugerem que o IFNy participe do processo de adaptação muscular ao exercício ou de reparo. O aumento mais importante dos 
níveis sanguíneos nos cavalos desse estudo ocorreu tardiamente, de 3 a 14 dias após a prova, o que pode reforçar a hipótese dos autores anteriormente citados.

A IL-2 aumentou em todos os momentos nos cavalos de $80 \mathrm{~km}$ e sete e quatorze dias depois nos de $120 \mathrm{~km}$ sem suplementação. Nos cavalos de $160 \mathrm{~km}$ houve diminuição em todos os momentos. Nos suplementados, houve aumento em três horas, três, sete e quatorze dias após nos cavalos de $80 \mathrm{~km}$. Nos de $120 \mathrm{~km}$ não houve alteração e nos de $160 \mathrm{~km}$ aumentou logo após a prova, três horas, três e sete dias.

Franchimont et al. (2000) e Elenkov e Chrousos (1999) demonstraram tanto com humanos quanto com camundongos, in vitro e in vivo, que as células $T$ produtoras de IFNy e IL-2 são suprimidas pela epinefrina e cortisol, hormônios que aumentam durante e em resposta ao exercício. O cortisol age inibindo a produção de IL-12 pelas células apresentadoras de antígeno e diminuindo a habilidade dos linfócitos $T$ de responderem a essa interleucina. A IL-12 pró-inflamatória produzida e secretada por macrófagos após a ativação pela célula apresentadora de antígenos e sua principal função é aumentar a secreção de IFNy pelas células NK e pelos linfócitos T CD4. A epinefrina também suprime células $T$ tipo 1 tanto pela diminuição da apresentação de antígenos quanto agindo diretamente sobre receptores dos linfócitos.

Com a redução do glicogênio durante o exercício prolongado, há inflamação muscular localizada, o que aumenta os níveis de IL-6 que também contribui para o predomínio de células $T_{\mathrm{h} 2}$ após o exercício. Essa interleucina estimula a produção de $L T C D 8^{+}$, influenciando no balanço $T_{h 1} / T_{h 2}$. Além disso, a inflamação muscular causa um influxo de células $\mathrm{T} \mathrm{CD4}^{+}$para o local, contribuindo assim, para a diminuição dessas células na circulação (STEENSBERG et al., 2001). Os cavalos não suplementados de 80 e $120 \mathrm{~km}$ desse estudo apresentaram aumento de IL-2 a partir de três horas após a prova, persistindo até 14 dias. Os cavalos de $160 \mathrm{~km}$ apresentaram diminuição. Porém, a dinâmica da IL-2 não condiz com a dinâmica da relação CD4/CD8 nesses cavalos, pois houve diminuição dessa relação nos animais de $80 \mathrm{~km}$ a partir de três dias depois e houve aumento da IL-2 a partir de três horas após a prova. Houve diminuição da relação CD4/CD8 nos cavalos de $120 \mathrm{~km}$ a partir de três horas, que permaneceu diminuída até quatorze dias após a prova e a IL-2 aumentou sete e quatorze dias depois. Os cavalos de $160 \mathrm{~km}$ apresentaram aumento CD4/CD8 em no final da prova e três horas depois, diminuição três e sete 
dias e aumento novamente quatorze dias após. As concentrações de IL-2 desses cavalos sofreu diminuição logo após a prova e permaneceram baixas até quatorze dias depois. Uma possível explicação é que apesar das células $T_{h 1}$ sofrerem diminuição na corrente sanguínea, pode ser que mantenham a capacidade de síntese e liberação de IL-2 ou que os linfócitos que migraram para a musculatura produziram IL-2 em níveis detectáveis na corrente sanguínea. O efeito da suplementação com glutamina foi visível nos cavalos de $120 \mathrm{~km}$ que apresentaram níveis de IL-2 inferiores aos que não receberam suplementação, como é ilustrado nas figuras 11 e 12. Nos cavalos de $160 \mathrm{~km}$ houve aumento desde M1 até M4, ao contrário do que ocorreu nos que não receberam suplementação.

Figura 11 - Diferença na concentração de IL-2, em M3 nos cavalos de $120 \mathrm{~km}$, quanto à suplementação com glutamina

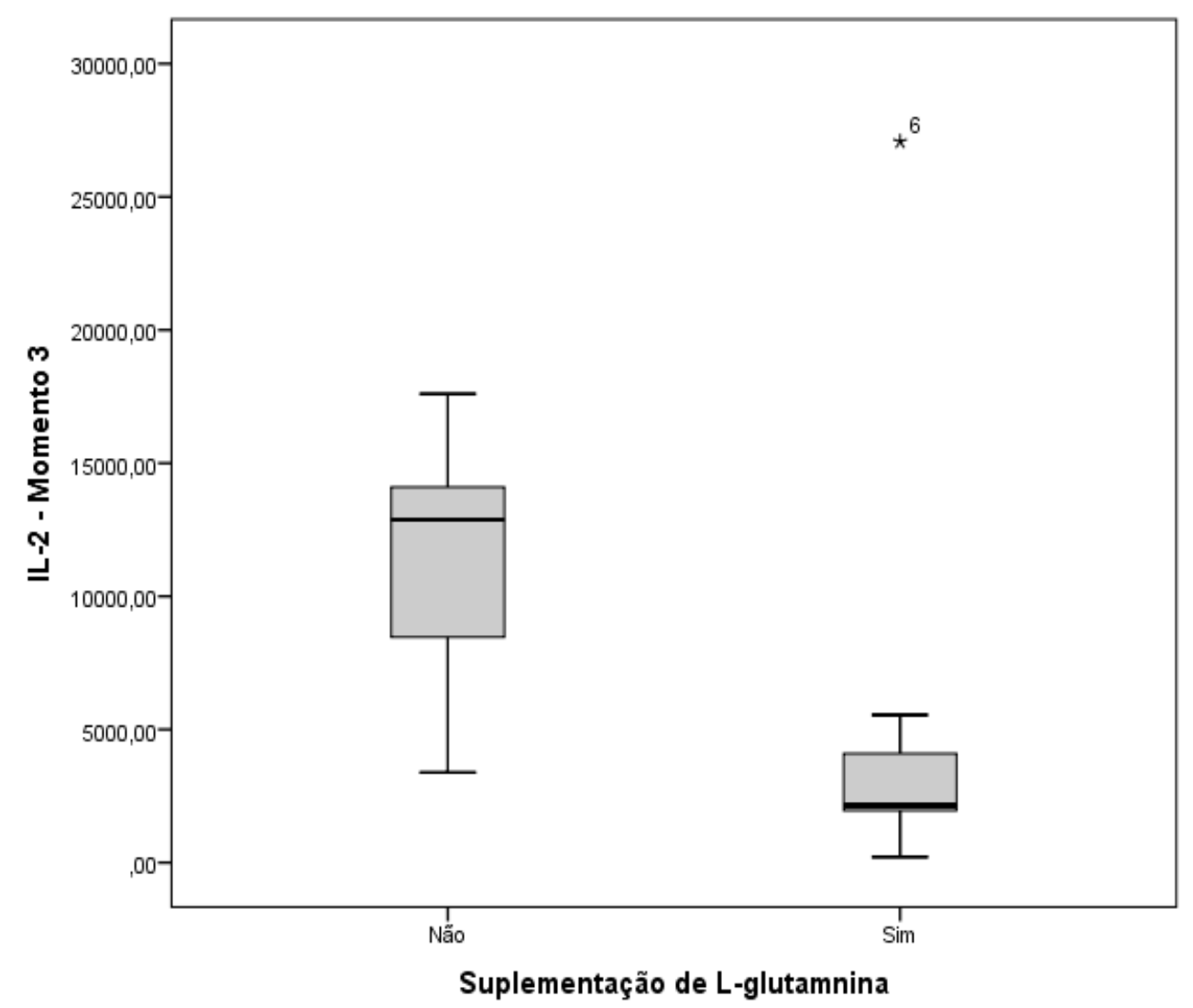


Figura 12 - Diferença na concentração de IL-2, em M5 nos cavalos de $120 \mathrm{~km}$, quanto à suplementação com glutamina

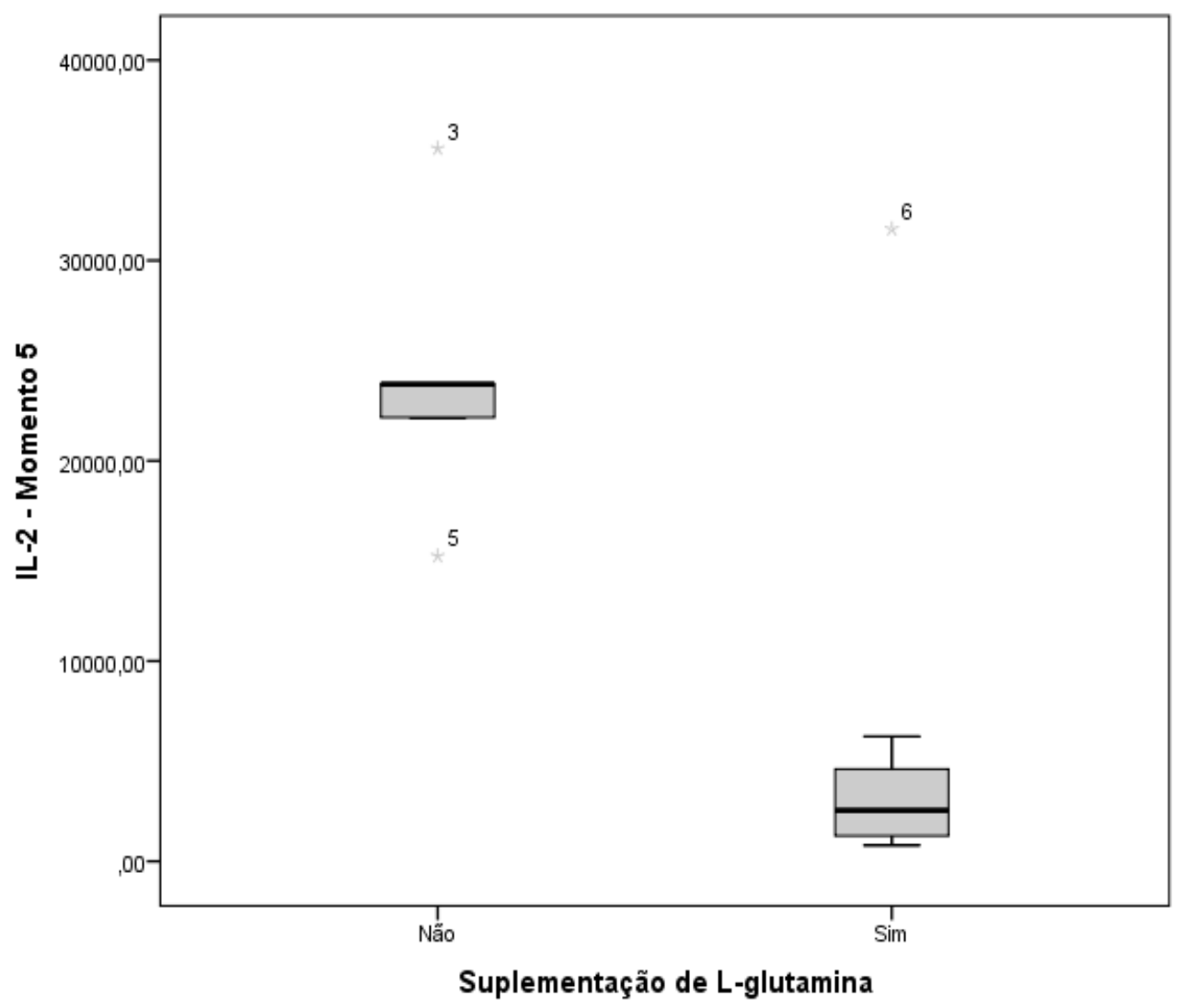

Elenkov e Chrousos (1999); Franchimont et al. (2000) e lbfelt et al. (2002) estudaram o efeito do exercício extenuante sobre citocinas com perfil $T_{h 1}$ e $T_{h 2}$ em atletas humanos e camundongos e não encontraram alterações em IL-4 após o exercício, nem relação entre os hormônios cortisol e epinefrina nas concentrações dessa citocina. A dinâmica das concentrações de IL-4 nesse estudo pareceu mais coerente com a dinâmica da relação CD4/CD8. Houve aumento em M4 e M5 nos cavalos de $80 \mathrm{~km}$ sem suplementação, onde houve diminuição de CD4/CD8 e aumento após a prova nos com suplementação, onde também ocorreu diminuição de CD4/CD8. Nos cavalos de $120 \mathrm{~km}$ sem suplementação houve aumento de IL-4 logo após a prova e três horas depois e diminuição de CD4/CD8 nos mesmos momentos, mas essa persistiu até quatorze dias. Nos suplementados, houve aumento de IL-4 desde o momento após a prova até quatorze dias, sendo que esse aumento foi significativamente maior que os não suplementados três, sete e quatorze dias, conforme ilustram as figuras 13, 14 e 15. Ambos os resultados mantiveram a coerência com a dinâmica de CD4/CD8. Nos animais de $160 \mathrm{~km}$ que 
não receberam glutamina houve aumento em M1, M4 e M5porém a relação CD4/CD8 só estava diminuída em M4. Nos que receberam, houve diminuição de IL4 em M1, embora esses cavalos tenham apresentado níveis superiores dessa interleucina desde $\mathrm{MO}$ em relação aos não suplementados.

Figura 13 - Diferença na concentração de IL-4, em M3 nos cavalos de 120 km, quanto à suplementação com glutamina

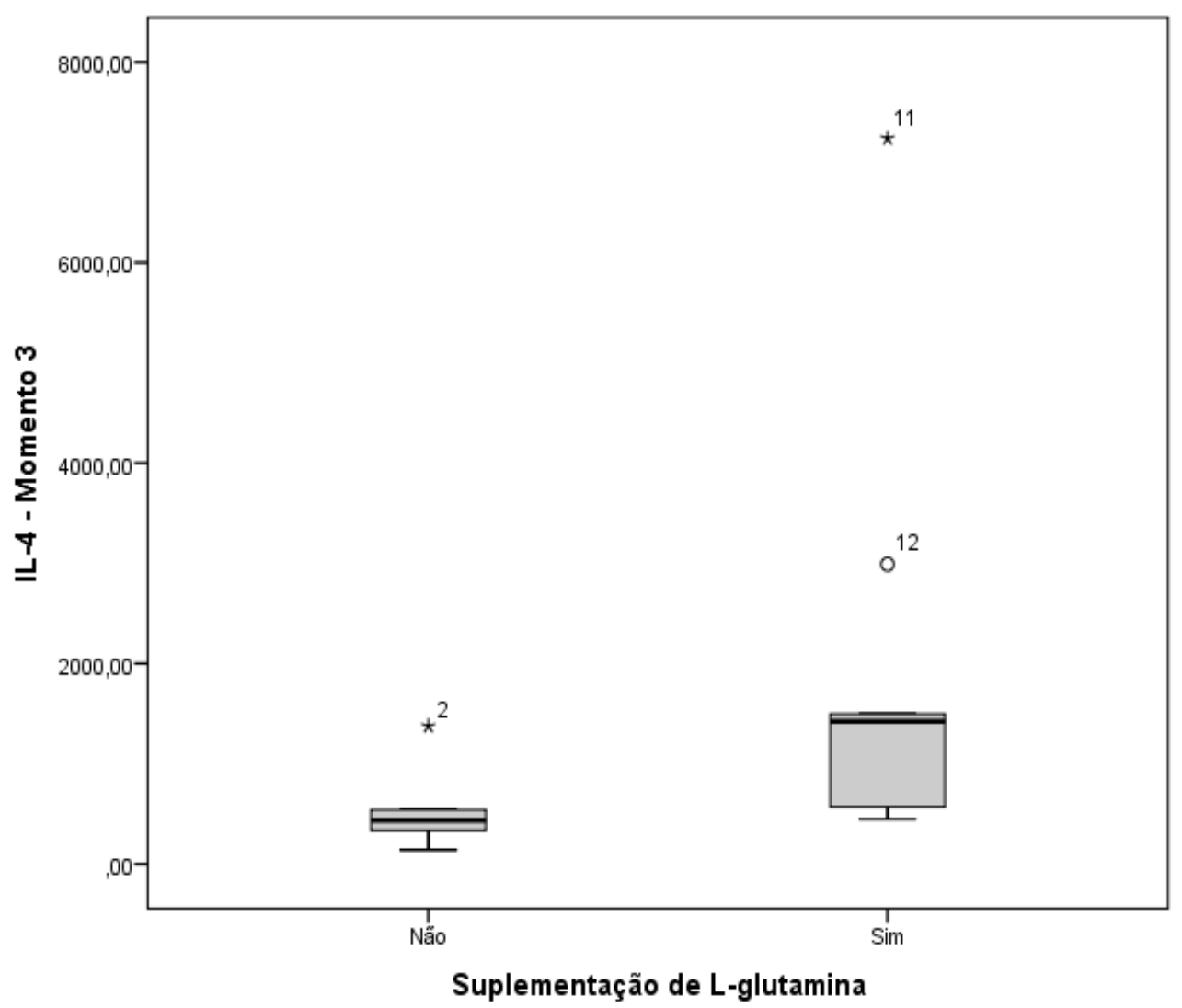


Figura 14 - Diferença na concentração de IL-4, em M4 nos cavalos de $120 \mathrm{~km}$, quanto à suplementação com glutamina

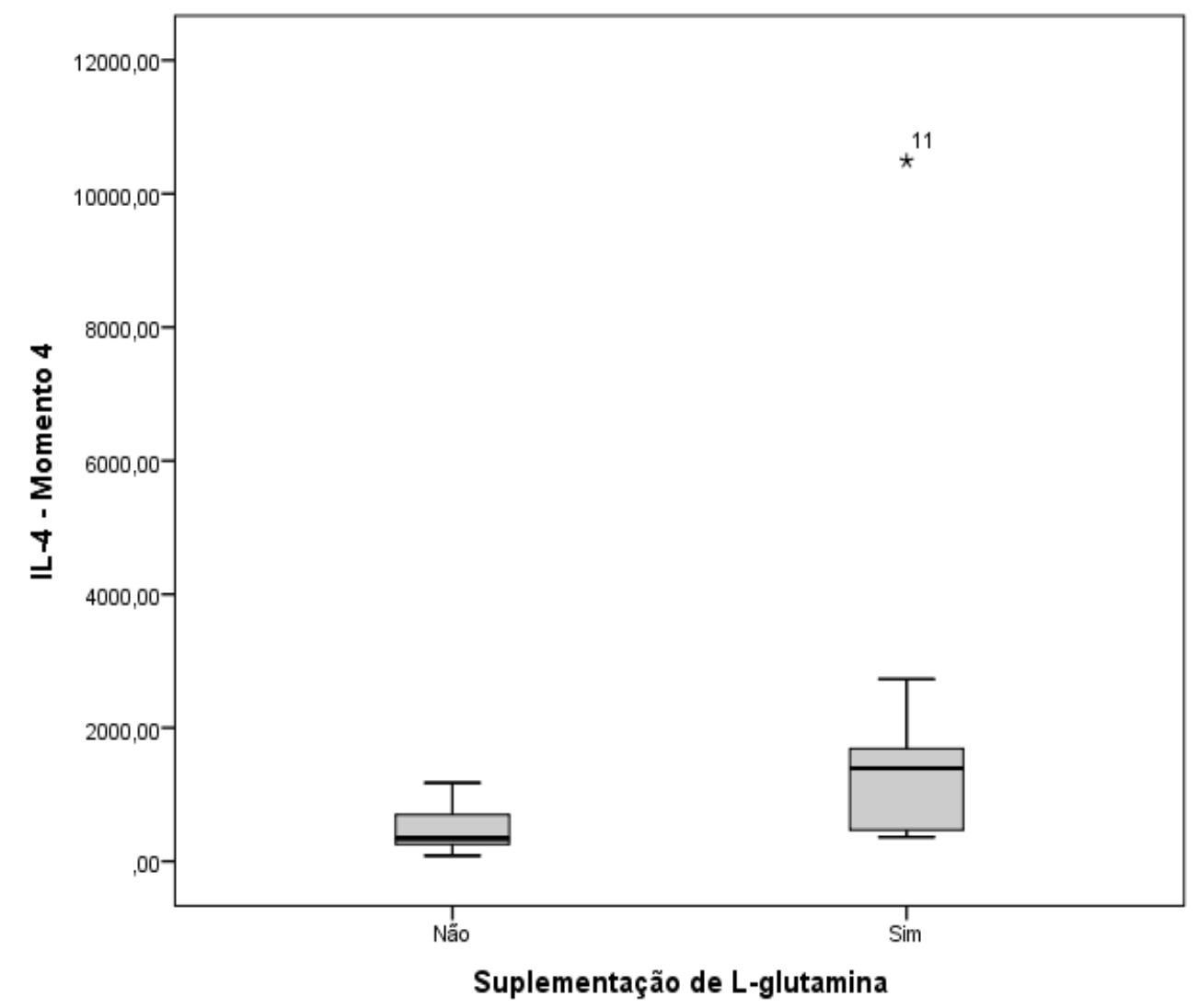


Figura 15 - Diferença na concentração de IL-4, em M5 nos cavalos de $120 \mathrm{~km}$, quanto à suplementação com glutamina

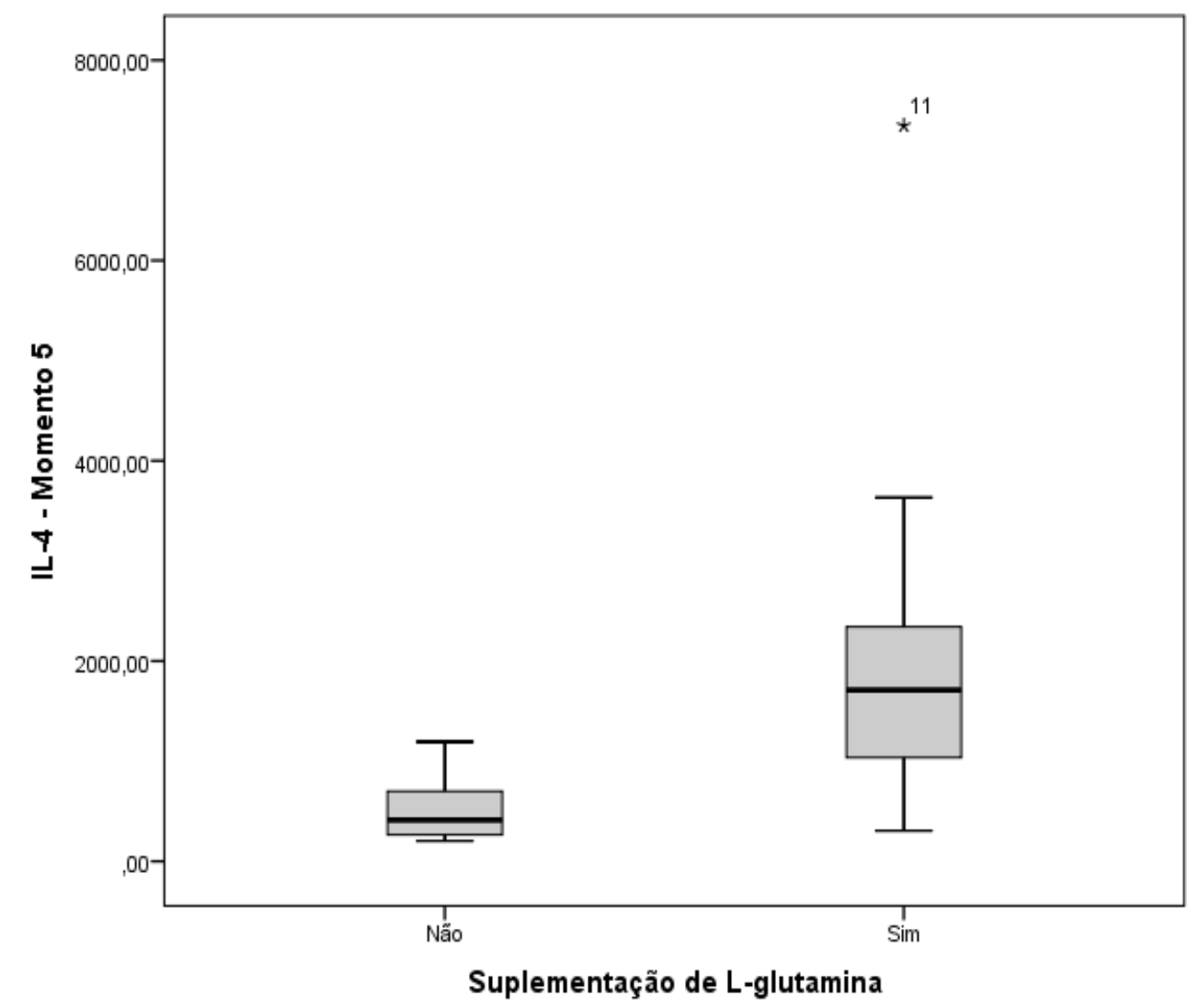

As concentrações de IL-10 aumentaram em três horas após a prova nos cavalos de 80 km sem suplementação e de três horas até sete dias nos com suplementação. Todos os cavalos de $120 \mathrm{~km}$ mostraram aumento desde o momento após a prova até sete dias depois, mas, nos que receberam suplementação esse aumento permaneceu até quatorze dias. Todos os cavalos de $160 \mathrm{~km}$ apresentaram aumento desde o pós prova até quatorze dias.

A IL-10 é produzida por linfócitos $T_{h 2}\left(C D 8^{+}\right)$e $T_{\text {reg }}$ e muitas outras como linfócitos $B$, mastócitos, eosinófilos, macrófagos e células dendríticas. Possui ampla gama de propriedades anti-inflamatórias como a inativação de macrófagos e maturação de células dendríticas, inibindo assim, a secreção de citocinas pró-inflamatórias (TNF) e expressão do MHC de classe II. Também inibe a produção de IL-12 por macrófagos e células dendríticas o que faz com que essa interleucina tenha um efeito supressor direto sobre a resposta de linfócitos $T_{h 1}$ (O'GARRA; VIEIRA, 2007). O aumento da IL-10 e IL-1ra na circulação após exercícios prolongados demonstra um efeito anti-

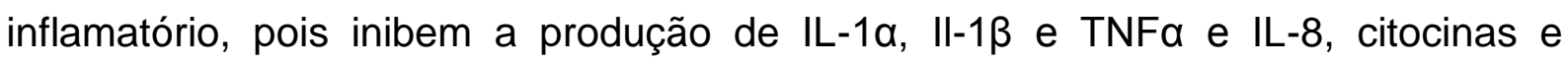


quimiocinas que desempenham importantes papéis na ativação de granulócitos, NK e linfócitos $T$ e $B$, assim como o recrutamento dessas células para o local da inflamação. Dessa forma, pode-se concluir que a IL-10 regula a resposta inflamatória que envolve principalmente a ativação de macrófagos e monócitos (PETERSEN; PEDERSEN, 2005). O aumento de IL-10 nos cavalos desse estudo que não receberam suplementação parece ter sido dependente do esforço, ou seja, da distância percorrida. Os cavalos de $80 \mathrm{~km}$ apresentaram aumento três horas após a prova, os de $120 \mathrm{~km}$ três horas, três e sete dias e os de $160 \mathrm{~km}$ em todos os momentos, sendo que níveis mais altos foram encontrados 14 dias após a prova.

Se a inflamação muscular for proporcional à depleção de glicogênio e se os processos de reparação muscular e regeneração desse glicogênio ocorrem alguns dias após a competição, esses resultados mostram que a IL-10 também age nos equinos como age nos humanos, modulando a resposta inflamatória. Nos cavalos que receberam glutamina, esse aumento foi mais prolongado, ou seja, nos cavalos de $80 \mathrm{~km}$ permaneceu até sete dias após a prova e nos de $120 \mathrm{~km}$ até quatorze dias. Se linfócitos utilizam glutamina como fonte de energia, podemos concluir que houve uma ação nesse sentido, pois não só os níveis de IL-10 aumentaram em cavalos suplementados, mas também os de IL-2 e IL-4. 


\section{CONCLUSÕES}

De acordo com os dados obtidos nesse estudo não foi possível concluir que os cavalos submetidos a diferentes níveis de esforço, imposto pelas diferentes distâncias (80, 120 e $160 \mathrm{~km}$ ) apresentaram estresse.

A alteração na relação CD4/CD8 foi mais tardia do que é descrito em outras espécies, ocorrendo somente três horas a três dias após a prova.

Apesar de haver diminuição do número circulante de LT CD4, não houve alteração nas interleucinas de $T_{h 1}$. Por isso, não foi possível observar imunodepressão causada pelo enduro.

A suplementação com glutamina atenuou o aumento de cortisol logo após o exercício nos cavalos de 80 e $160 \mathrm{~km}$ e teve um efeito nos linfócitos observado pelo aumento tanto da relação LT CD4/CD8 ou na manutenção desse equilíbrio quanto na produção de citocinas de $T_{h 1}$ e $T_{h 2}$. 


\section{REFERÊNCIAS}

AEBI, H. Catalase. Methods in Enzymology, v. 105, p. 121-126, 1984.

AGOSTINI, F.; BIOLO, G. Effect of physical activity on glutamine metabolism. Current. Opinion. Clinical. Nutrition. Metabolism. Care, v. 13, p. 58-64, 2010.

ANDERSON, N. V.; YOUANES, Y. D.; VESTWEBER, J. G.; KING, C. A.; KLEMM, R. D.; KENNEDY, G. A. The effects of stressful exercise on leukocytes in cattle with experimental pneumonic Pasteurellosis. Veterinary Research Communications, v. 15, p. 189-204, 1991.

ARNOUD, A.; RAMIREZ, M.; BAXTER, J. H.; ÂNGULO, A. J. Absorption of enterally administered $\mathrm{N}$-acetil-L-glutamine versus glutamine in pigs. Clinical Nutrition, v. 23, p. $1303-1312,2004$.

BALOGH, N.; GAÁL, T.; RIBICZEYNÉ, P. S.; PETRI, A. Biochemical and atioxidant changes in plasma and erythrocytes of pentathlon horses before and after exercise. Veterinary Clinical Pathology, v. 30, n. 4, p. 214-218, 2001.

BASSIT, R.; SAWADA, L. A.; BACURAU, R. F. P.; NAVARRO, F.; MARTINS JR., E.; COSTA, L. F. B. P. The effect of BCAA supplementation upon the immune response of triathletes. Medicine and Science in Sports and Exercise, v. 32, p. 1196-1201, 2000.

BAUM, M.; MULLER-STEINHARDT, M.; LIESEN, H.; KIRCHNER, H. Moderate and exhaustive endurance exercise influences the interferon-gamma levels in wholeblood culture supernatants. European Journal of Applied. Physiology, v. 76, p. 165-169, 1997.

BOWTELL, J. L.; GELLY, K.; JACKMAN, M. L.; PATEL, A.; SIMEONI, M.; RENNIE, M. J. Effect of oral glutamine on whole body carbohydrate storage during recovery from exhaustive exercise. Journal of Applied Physiology, v. 86, p. 1770-1777, 1999.

CASTELL, L. Glutamine supplementation in vitro and in vivo, in exercise and immunodepression. Sports Medicine, v. 33, p. 323-345, 2003.

CASTEL, L.; POORTMANS, J. R.; LECLERCQ, R.; BRASSEUR, M.; DUCHATEAU, J.; NEWSHOLME, E. A. Some aspects of the acute phase response after a marathon race, and the effect of glutamine supplementation. European Journal of Applied Physiology, v. 75, p. 47-53, 1997.

CAHILL, C. M.; VAN DER KOLK, H.; GOODE, J.A.; HAYDEN, T. J. Development of homologous radioimmunoassays for equine growth hormone and equine prolactin and their application to the detection of circulating levels of hormone in horse plasma.

Reproduction, Nutrition, Development, v. 34, p. 309-328, 1994.

CALLARD, R. E. Decision-making by the immune response. Immunology and Cell Biology, v. 85, p. 300-305, 2007. 
CASTEL, L.; VANCE, C.; ABBOTT, R.; MÁRQUEZ, J.; EGGLETON, P. Granule localization of glutaminase in human neutrophils and the consequence of glutamine utilization for neutrophil activity. Journal of Biological Chemistry, v. 279, p. 1330513310, 2004.

CAYADO, P.; MUÑOZ-ESCASSI, B.; DOMÃ-NGUEZ, C.; MANLEY, W.; OLABARRI, B.; CASTEJON, F.; MARAÑON, G.; VARA, E. Hormone response to training and competition in athletic horses. Equine Veterinary Journal, v. 36, p. 274-278, 2006. Supplement.

CHANG, W. K.; YANG, K. D.; WANG, J. F.; SHAIO, M. F. Lymphocyte proliferation modulated by glutamine: involved in the endogenous redox reaction. Clinical Experimental Immunology, v. 117, p. 482-488, 1999.

CHRISTENSEN, R.; MALINOWSKI, A.; SCANES, C. G.; HAFS, H. D. Pulsatile release of somatotropin related to meal feeding and somatotropin response to secretagogues in horses. Journal of Animal Science, v. 75, p. 2770-2777, 1997.

COWLES, W. Fatigue as a contributory cause of pneumonia. Boston Medicine and . Surgery. Journal, v. 179, p. 555-557, 1918.

CRUZAT, V. F.; PETRY, E. R.; TIRAPEGUI, J. Glutamina: aspectos bioquímicos, metabólicos, moleculares e suplementação. Revista Brasileira de Medicina do Esporte, v. 15, n. 5, p. 167-174, 2009.

CUNHA, W. D. S.; FRIEDLER, G.; VAISBERG, M.; SEALANDER, M. L. C.; COSTA, L. F. $D$. P. Exercise restores immune cell function in energy restrict rats. Medicine and Science in Sports and Exercise, v. 36, p. 2059-2064, 2004.

CYWIŃSKA, A.; WYSZYŃSKA, Z.; GÓRECKA, R.; SZARSKA, E.; WITKOWSKI, L.; DZIEKAN, P.; WINNICKA, A.; SCHOLLENBERGER, A. The effect of the $162 \mathrm{~km}$ endurance ride on equine peripheral blood neutrophil and lymphocyte functions. Polish Journal of Veterinary Sciences, v. 13, n. 2, p. 279-285, 2010.

CYWIŃSKA, A.; SZARSKA, E.; GÓRECKA, R.; WITKOWSKI, L.; WYSZYÑSKA, Z.; HECOLD, M.; BEREZNOWSKI, A. J.; SCHOLLENBERGER, A.; WINNICKA, A. Lymphocyte proliferation activity after limited (Light class) and long (CEI) distance endurance rides in horses. Central European Journal of Immunology, v. 37, n. 4, p. 326-331, 2012.

DEATON, C. M.; MARLIN, D. J. Exercise-associated oxidative stress. Clinical Techniques in Equine Practice, v. 2, n. 3, p. 278-291, 2003.

DEATON, C. M.; MARLIN, D. J.; ROBERTS, C. A.; SMITH, N.; KELLY, F. J.; HARRIS, P. A.; SCHROTER, R. C. Antioxidant supplementation and pulmonary function at rest and exercise. Equine Veterinary Journal, v. 34, n. S34, p. 58-65, 2002.

DÉCHELOTTE, P.; DARMAUN, D.; RONGIER, M.; HECKETSWEILER, B.; DESJEUX, J. Absorption and metabolic effects of enterally administered glutamine in humans.

American Journal of Physiology, v. 260, p. 677-682, 1991. 
DOHMANN, K.; WAGNER, HOROHOV, D. W.; LEIBOLD, W. Expression and characterization of equine interleukin 2 and interleukin 4 . Veterinary Immunology and Immunopathology, v. 77, p. 243-256, 2000.

DRÖGE, W.; BREITKREUTZ, R. Glutathione and immune function. Nutrition Society, v. 59, p. 595-600, 2000.

DUFAUX, B.; HEINE, O.; PRINZ, U.; SOLL, C.; ROST, R. Effect of short maximal physical exercise on the eosinophil cationic protein. International Journal of Sports and Medicine, v.14, p. 468-470, 1993.

ELENKOV, I. J.; CHROUSOS, G. P. Stress hormones, Th1/Th2 patterns, pro/antiinflammatory cytokines and susceptibility to disease. Trends Endocrinology and Metabolism, v. 10, p. 359-368, 1999.

ESBJÖRNSSON, M.; BÜLOW, j.; NORMAN, B.; SIMONSEN, L.; NOWAK, J.; ROOYACKERS, O.; KAIJSER, L.; JANSSON, E. Adipose tissue extracts plasma ammonia after sprint exercise in women and men. Journal of Applied Physiology, v. 101, p.15761580, 2006.

FERRAZ, G. C.; TEIXEIRA-NETO, A. R.; PEREIRA, M. C.; LINARDI, R. L.; LACERDANETO, J. C.; QUEIROZ-NETO, A. Influência do treinamento aeróbio sobre o cortisol e glicose plasmáticos em equinos, Arquivo Brasileiro de Medicina Veterinária e Zootecnia, v. 62, n. 1, p. 23-29, 2010.

FOZ, N. B.; QUEIROZ-NETO, A.; FERRAZ, G. C.; GRANER, C.; MASSOCO, C. O.; MACHADO, R. Z. Evaluation of T cell CD4 and CD8 population ratio in elite polo ponies submitted to lactate minimum speed (LMS) - a preliminary study. In: INTERNATIONAL CONGRESS OF WORLD EQUINE VETERINARY ASSOCIATION, 11., 2009, Guarujá, SP, Brazil. Proceedings... 2009.

FRANCHIMONT, D.; GALON, J.; GADINA, M.; VISCONTI, R.; ZHOU, Y.; ARINGER, M.; FRUCHT, D. M.; CHROUSOS, G. P.; O'SHEA, J. J. Inhibition of Th1 immune response by glucocorticoids: dexamethasone selectively inhibits IL-12-induced Stat4 phosphorylation in T lymphocytes. Journal of Immunology, v.164, p. 1768-1774, 2000.

GLEESON, M. Immune function in sport and exercise. Journal of Applied Physiology, v. 103, p. 693-699, 2007.

GLEESON, M.; BISHOP, N. C. The T cell and NK cell immune response. Annals of Transplantation, v. 10, n. 4, p. 44-49, 2009.

GRAAF-ROELFSEMA, E.; KEIZER, H. A.; VAN BREDA, E.; WIJNBERG, I. D.; VAN DER KOLK, J. H. Hormonal responses to acute exercise, training and overtraining a review with emphasis on the horse. Veterinary Quartely, v. 29, n. 3, p. 82-101, 2007.

GRAAF-ROELFSEMA, E.; VELDHUIS, P. P.; KEIZER, H. A.; VAN GINNEKEN, K. G.; VAN BREDA, E.; WIJNBERG, I. D.; VAN DER KOLK, J. H. Overtrained horses alter their resting pulsatile growth hormone secretion. American Journal of Physiology and Regulatory, Integrity and Comparative Physiology, v. 297, p. 403-411, 2009. 
HAAHR, P. M.; PEDERSEN, B. K.; FOMSGAARD, A.; TVEDE, N.; DIAMANT, M.; KLARLUND, K.; HALKJAER-KRISTENSEN, J.; BENDTZEN, K. Effect of physical exercise on in vitro production of interleukin-1, interleukin-6, tumor necrosis factor-alpha, interleukin 2 and interferon-gamma. International Journal of Sports and Medicine., v. 12, p. 223227, 1991.

HARGREAVES, B. J.; KRONFELD, D. S.; WALDRON, J. N.; LOPES, M. A.; GAY, L. S.; SAKER, K. E.; COOPER, W. L.; SKLAN, D. J.; HARRIS, P. A. Antioxidant status and muscle cell leakage during exercise. Equine Veterinary Journal, v. 34, p. 116-121, 2002a. Supplement.

HARGREAVES, B. J.; KRONFELD, D. S.; WALDRON, J. N.; LOPES, M. A.; GAY, L. S.; SAKER, K. E.; COOPER, W. L.; SKLAN, D. J.; HARRIS, P. A. Antioxidant status of horses during two $80-\mathrm{km}$ endurance races. The Journal of Nutrition, v. 132, p. 1781-1783S, $2002 b$.

HARRIS, R. C.; HARRIS, P. A.; ROUTLEDGE, N. B. H.; NAYLOR, J. R. J.; WILSON, A. M. Plasma glutamine concentrations in the horse following feeding with or without oral glutamine supplementation. Equine Veterinary Journal, v. 36, p. 637-642, 2006.

HINES, M. T.; SCHOTT II, H. C.; BAYLY, W. M.; LEROUX, A. J. Changes in limphocytes subpopulations following prolonged exercise in horses. In: ANNUAL VETERINARY MEDICAL FORUM, 12., 1994, San Francisco, CA. Proceedings... 1994. p. 1016.

HINES, M. T.; SCHOTT II, H. C.; BAYLY, W. M.; LEROUX, A. J. Exercise and immunity: a review with enphasis on the horse. Journal of Veterinary Internal Medicine, v. 10, n. 5, p. 280-289, 1996.

HYYPPÄ, S. Endocrinal responses in exercising horses. Livestock Production Science, v. 92, p. 113-121, 2005.

IBFELT, T.; PETERSEN, E. W.; BRUUNSGAARD, H.; SANDMAND, M.; PEDERSEN, B. $\mathrm{K}$. Exercise-induced change in type 1 cytokine-producing CD8_T cells is related to a decrease in memory T cells. Journal of Applied Physiololy, v. 93, p. 645-648, 2002.

IRVINE, C. H. G.; ALEXANDER, S. L. Factors affecting the circadian rhythm in plasma cortisol concentrations in the horse. Domestic Animal Endocrinology, v.11, n. 2, p. 227238, 1994.

JENSEN-WAERN, M.; FOSSUM, C. Effects of acute physical stress on immune competence in pigs. American Journal of Veterinary Science, v. 54, p. 596-601, 1993.

KARGOTISH, S.; ROWBOTTON, D. G.; KEAST, D. Plasma glutamine changes after high intensity exercise in elite male swimmers. Research in Sports Medicine, v. 13, p. 7-21, 2005.

KARGOTISH, S.; KEAST, D.; GOODMAN, C. Monitoring 6 weeks of progressive endurance training with plasma glutamine. International Journal of Sports and Medicine, v. 28, p. 211-216, 2007. 
KELLEY, K. W. From hormones to immunity: the physiology of immunology. Brain Behavour Immunology, v.18, p. 95-113, 2004.

KELLEY, K. W.; WEIGENT, D. A.; KOOIJMAN, R. Protein hormones and immunity. Brain Behavour Immunology., v. 21, n. 4, p. 384-392, 2007.

KIMURA, H.; SUZUI, M.; NAGAO, F.; MATSUMOTO, K. Highly sensitive determination of plasma cytokines by time-resolved fluoroimmunoassay; effect of bicycle exercise on plasma level of interleukin-1 alpha (IL-1 alpha), tumor necrosis factor alpha (TNF alpha), and interferon gamma (IFN gamma). Anal. Sci., v. 17, p. 593-597, 2001.

KINNUNEN, S.; ATALAY, M.; HYYPPÄ, S.; LEHMUSKERO, A.; HÄNNINENO.; OKSALA, $\mathrm{N}$. Effects of prolonged exercise on oxidative stress and antioxidant defense in endurance horse. Journal of Sports and Medicine, v. 4, p. 415-421, 2005.

KIRSCHVINK, N.; MOFFARTS, B.; LEKEUX, P. The oxidant/antioxidant equilibrium in horses. The Veterinary Journal, v. 177, p. 178-191, 2008.

KURCZ, E. V.; LAWRENCE, L. M.; KELLEY, K. W.; MILLER, P. A. The effect of intense exercise on the cell-mediated immune response of horses. Journal of Equine Veterinary Science, v. 8, n. 3, p. 237-239, 1998.

KRUMRYCH, W. Variability of clinical and haematological indices in the course of training exercise in jumping horses. Bull Veterinary Institute Pulawy, v. 50, p. 391-396, 2006.

LANCASTER, G. I.; HALSON, S. L.; KHAN, Q.; DRYSDALE, P.; JEUKENDRUP, A. E.; DRAYSON, M. T.; GLEESON, M. The effects of acute exhaustive exercise and intensified training on type 1/type $2 \mathrm{~T}$ cell distribution and cytokine production. Excercise Immunology Review, v. 10, p. 91-106, 2004.

LANCASTER, G. I.; KHAN, Q.; DRYSDALE, P.; JEUKENDRUP, A. E.; DRAYSON, M. T.; GLEESON, M. Effect of prolonged exercise and carbohydrate ingestion on type 1 and type $2 \mathrm{~T}$ lymphocyte distribution and intracellular cytokine production in humans. Journal of Applied Physiology, v. 98, p. 565-571, 2005.

LIBURT, N. R.; MCKEEVER, K. H.; STRELTSOVA, J. M.; FRANKE, W. C.; MANSO FILHO, H. C.; HOROHOV, D. W.; ROSEN, R. T.; HO, C. T.; SINGH, A. P.; VORSA, N. Effects of cranberry and ginger on the physiological response to exercise and markers of inflammation following acute exercise in horses. Comparative Exercise

Physiology, v. 6, p. 157-169, 2010.

LIBURT, N. R.; ADAMS, A. A.; BETANCOURT, A.; HOROHOV, D. W.; McKEEVER, K. H. Exercise-induced increases in inflammatory cytokines in muscle and blood of horses.

Equine Veterinary Journal, v. 42, p. 280-288, 2010. Supplement, 38.

LUNN, D. P.; HUSSEY, S.; SEBING, R.; RADECKI, S. V.; RUSHLOW, K. E.; WHITAKERDOWLING, P.; YOUNGNER, J. S.; CHAMBERS, T. M.; HOLLAND, R. E.; HOROHOV, D. W. Safety, efficacy, and immunogenicity of a modified-live equine influenza virus vaccine in ponies after induction of exercise-induced immunosuppression. Journal of American Veterinary Medicine Association, v.15, n. 6, p. 900-906, 2001. 
MACIVER, N. J.; JACOBS, S. R.; WIEMAN, H. L.; WOFFORD, J.A.; COLOFF, J. L.; RATHMELL, J.C. Glucose metabolism in lymphocytes is a regulated process with significant effects on immune cell function and survival. Journal of Leukocyte Biology, v. 84, n. 4, p. 949-957, 2008.

MARC, M.; PARVIZI, N.; ELLENDORFF, F.; KALLWEIT, E.; ELSAESSER, F. Plasma cortisol and ACTH concentrations in the warmblood horse in response to a standardized treadmill exercise test as physiological markers for evaluation of training status. Journal of Animal Science, v. 78, p. 1936-1946, 2000.

MARLIN, D. J.; FENN, K.; SMITH, N.; DEATON, C. D.; ROBERTS, C. A.; HARRIS, P. A.; DUNSTER, C.; KELLY, F. J. Changes in circulatory antioxidant status in horses during prolonged exercise. Journal of Nutrition, v. 132, p. 1622S-1627S, 2002.

McKEEVER, K. H. The endocrine system and the challenge of exercise. Veterinary Clinics of North America Equine Practitioners, v. 18, p. 321-353, 2002.

McKUNE, A. J.; SMITH, L. L.; SEMPLE, S. J.; WADEE, A. A. Non-allergic activation of eosinophils after strenuous endurance exercise. Sports Medicine, v. 16, n. 2, p. 12-16, 2004.

NESSE, L. L.; JOHANSEN, G. I.; BLOM, A. K. Effects of racing on lymphocyte proliferation in horses. American Journal of Veterinary Research, v. 63, p. 528-530, 2002.

NEWSHOLME, P.; LIMA, M. M. R.; PROCOPIO, J.; PITHON-CURI, T. C.; DOI, S. Q.; BAZOTTE, R. B.; CURI, R. Glutamine and glutamate as vital metabolites. Brazilian Journal of Medical and Biological Research, v. 36, n. 2, p. 153-163, 2003.

NIELSEN, H. B. Lymphocyte responses to maxima exercise. Sports Medicine, v. 33, n. 11, p. 853-867, 2003.

NIEMAN, D. C.; HENSON, D. A.; SAMPSON, C. S.; HERRING, J. L.; SUTTLES, J.; CONLEY, M.; STONE, H. M.; BUTTERWORTH, D. E.; DAVIS, J. M. The acute immune response to exhaustive resistance exercise. International Journal of Sports and Medicine, v. 16, p. 322-328, 1995.

NIEMAN, D. C. Risk of upper respiratory tract infection in athletes: an epidemiologic and immunologic perspective. Journal of Athletic Training, v. 32, p. 344-349, 1997.

NORTHOFF, H.; BERG, A.; WEINSTOCK, C. Similarities and differences of the immune response to exercise and trauma: the IFN-gamma concept. Canadian Journal of Physiology Pharmacology, v. 76, p. 497-504, 1997.

O'GARRA, A.; VIEIRA, P. Th1 cells control themselves by producing interlukin-10. Nature, v. 7, p. $425-428,2007$.

PEDERSEN, B. K.; HOFFMAN-GOETZ, L. Exercise and the immune system: regulation, integration and adaptation. Physiological Reviews, v. 80, n. 3, p.1055-1081, 2000. 
PEDERSEN, B. K.; ROHDE, T.; OSTROWSKI, K. Recovery of the immune system after exercise. Acta Physiologica Scandinava, v. 162, p. 325-332, 1998.

PETERSEN, A. M.; PEDERSEN, B. K. The anti-inflammatory effect of exercise. Journal of Applied Physiology, v. 98, p. 1154-1162, 2005.

RAIDAL, S. L.; LOVE, D. N.; BAILEY, G. D.; ROSE, R. J. The effect of high intensity exercise on the functional capacity of equine pulmonary alveolar macrophages and BALderived lymphocytes. Research in Veterinary Sciences, v. 68, n. 3, p. 249-253, 2000.

RAIDAL, S. L.; ROSE, R. J.; LOVE, D. N.; BAILEY, G. D. Effects of training on resting peripheral blood and BAL-derived leukocyte function in horses. Equine Veterinary Journal, v. 33, n. 3, p. 238-243, 2001.

RADAK, Z.; CHUNG, H. Y.; GOTO, S. Systemic adaptation to oxidative challenge induced by regular exercise. Free Radical Biology \& Medicine, v. 44, p. 153-159, 2008.

REINER, S. L. Decision making during the conception and career of CD4+ T cells. Nature, v. 9 , p. 81-82, 2009.

RENNIE, M. J.; BOWTELL, J. L.; BRUCE, M.; KHOGALI, S. E. O. Interaction between glutamine availability and metabolism of glycogen, tricarboxylic acid cycle intermediates and glutathione. Journal of Nutrition, v. 131, p. 24885-24905, 2001.

RISøY, B. A.; RAASTAD, T.; HALLÉN, J.; LAPPEGARD, K. T.; BAEVERFJAORD, K.; KRAVDAL, A.; SIEBKE, E. M.; BENESTAD, H. B. Delayed leukocytosis after hard strength and endurance exercise: aspects of regulatory mechanisms. Biomed Central

Physiology, v. 3, p. 1-12, 2003.

ROBSON, P. J.; ALSTON, T. D.; MYBURGH, K. H. Prolonged suppression of the innate immune system in the horse following an $80 \mathrm{~km}$ endurance race. Equine Veterinary Journal, v. 35, p. 133-137, 2003.

SASTRE, J.; ASENSI, M.; GASKO, E.; PUZYNA, W. Exhaustive physical exercise causes oxidation of glutathione status: Prevention by antioxidant administration. American Journal of Physiology, v. 263, p. 992-995, 1992.

SCHNEIDER, C. D.; OLIVEIRA, A. R. Radicais livres de oxigênio e exercício: mecanismos de formação e adaptação ao treinamento físico. Revista Brasileira Medicina Esporte, v. 10, n. 4, p. 308-312, 2004.

SCHUMACHER, M. J.; BURKHEAD, T. Stability of fresh and preserved fetal and adult lymphocyte ceel surface markers. Journal of Clinical Laboratory Analysis, v. 14, p. 320-326, 2000.

SHIN, Y. O.; LEE, J. B. Leukocyte chemotactic cytokine and leukocyte subset responses during ultra-marathon running. Cytokine, v. 61, p. 364-369, 2013.

SPUTTEK, A.; KÜHNL, P.; ROWE, A. W. Cryopreservation of erythrocytes, thrombocytes and lymphocytes. Transfusion Medicine and Hemotherapy, v. 34, p. 262-267, 2007. 
STEENSBERG, A.; TOFT, A. D.; BRUUNSGAARD, H.; SANDMAND, M.; KRISTENSEN, J. H.; PEDERSEN, B. K. Strenuous exercise decreases the percentage of type $1 \mathrm{~T}$ cells in the circulation. Journal of Applied Physiology, v. 91, p. 1708-1712, 2001.

STEENSBERG, A.; FICHER, C. F.; KELLER, C.; MOLLER, K.; PEDERSEN, B. K. IL-6 enhance plasma IL-1 ra, IL-10 and cortisol in humans. American Journal of Physiology and Metabolism, v. 285, p. 433-437, 2003.

STRELTSOVA, J. M.; MCKEEVER, K. H.; LIBURT, N. R.; MANSO, H. C.; GORDON, M.E.; HOROHOV, D. W.; ROSEN, R.; FRANKE, W. F. Effect of orange peel and black tea extracts on markers of performance and cytokine markers of inflammation in horses.

Equine Compared Exercise Physiology, v. 3, p. 121-130, 2006.

SUN, L.; SHEN, W.; LIU, Z.; GUAN, S.; LIU, J. DING, S. Endurance exercise causes mitochondrial and oxidative stress in rat liver: Effects of a combination of mitochondrial targeting nutrients. Life Sciences, v. 86, p. 39-44, 2010.

SUSUKI, K.; TOTSUKA, M.; NAKAJI, S.; YAMADA, M. KUDOH, S.; LIU, Q.; SUGAWARA, K.; YAMAYA, K.; SATO, K. Endurance exercise causes interaction among stress hormones , cytokines, neutrophil dynamics and muscle damage. Journal of Applied Physiology, v. 87, p. 1360-1367, 1995.

SUZUKI, K.; NAKAJU, S.; YAMADA, M.; TOTSUKA, M.; SATO, K.; SUGAWARA, K. Systemic inflammatory response to exhaustive exercise. Cytokine Kinetics Exercise Immunology Reviews, v. 8, p. 6-48, 2002.

TEIXEIRA NETO, A. R. Variáveis fisiológicas e estresse oxidativo de equinos durante campeonato de enduro. 2006. $67 \mathrm{f}$. Tese (Doutorado em Ciências) Faculdade de Ciências Agrárias e Veterinária, Universidade Estadual Paulista, Jaboticabal, 2006.

VENGE, P. Eosinophisl. In:__. Asthma: basic mechanisms and clinical management. $3^{\text {rd }}$ ed. Oxford, Oxford University Press,1998. p. 142-157.

VARNIER, M.; LEESE, G. P.; THOMPSON, J.; RENNIE, M. J.; Stimulatory effect of glutamine on glycogen accumulation in human skeletal muscle. American Journal of Physiology and Endocrinology Metabolism, v. 269, p. 309-315, 1995.

VINA, J.; BORRAS, C.; GOMEZ-CABRERA, M. C.; ORR, W. C. Part of these series: from dietary antioxidants to regulators in cellular signilling and gene expression. Role of reactive oxygen species and (phyto)oestrogens in the modulation of adaptive responses to stress.

Free Radical Research, v. 40, p. 111-119, 2006.

YUAN, Y.; CHAN, K. M. A review of literature on the application of blood ammonia measurement in sport science. Research Quartarly for Exercise and Sport, v. 71, n. 2, p. $145-151,2000$. 
WAGNER, B.; BURTON, A.; AINSWORTH, D. Interferon-gamma, interleukin-4 and interleukin-10 production by $T$ helper cells reveals intact $T h 1$ and regulatory $T_{R} 1$ cell activation and a delay of the Th2 cell response in equine neonates and foals. Veterinary Research, v. 47, p. 1-12, 2010.

WALSH, N. P.; BLANIN, A. K.; CLARK, A. M.; ROBSON, P. J.; GLEESON, M. The effects of high intensity intermittent exercise on plasma concentrations of glutamine and organic acids. European Journal of Applied Physiology, v. 77, p. 434-438, 1998.

WEIGENT, D. A. Immunoregulatory properties of growth hormone and prolactin. Journal of Pharmacology and Therapeutics, v. 69, p. 237-257, 1996.

WEINBERG, A.; SONG, L. Y.; WILKENING, C.; SEVIN, A.; BLAIS, B.; LOUZAO, R.; STEIN, D.; DURAND, D.; FENTON, T. Optimization and limitations of use of cryopreserved peripheral blood mononuclear cells for functional and phenotypic T-cell characterization. Clinical and Vaccine Immunology, v. 16, n. 8, p. 1176-1186, 2009.

WEINSTOCK, C.; KONIG, D.; HARNISCHMACHER, R.; KEUL, J.; BERG, A.; NORTHOFF, $\mathrm{H}$. Effect of exhaustive exercise stress on the cytokine response. Medicine Sciences of Sports Exercise, v. 29, p. 345-354, 1997.

WILLIAMS, C. A.; KRONFELD, D. S.; HESS, T. M.; SAKER, K. E.; WALDRON, J. N.; CRANDELL, K. M.; HOFFMAN, R. M.; HARRIS, P. A. Antioxidant supplementation and subsequent oxidative stress of horses during an $80-\mathrm{km}$ endurance race. Journal of Animal Science, v. 82, p. 588-594, 2004.

WILLIER, S.; GARCIA, B.; CHAPMAN, B. E.; KUCHEL, P. W.; RAFTOS, J. E. Glutamine and $\alpha$-ketoglutarate as glutamate sources for glutathione synthesis in human erythrocytes. FEBS Journal, v. 278, p. 3152-3163, 2011.

ZHU, T.; STARLING-EMERALD, B.; ZHANG, X.; LEE, K. O.; GLUCKMAN, P. D.; MERTANI, H. C.; LOBIE, P. D. Oncogenic transformation of human mammary epithelial cells by autocrine human growth hormone. Cancer Research, v. 65, p. 317-324, 2005. 